\title{
Breeding Annual Grain Legumes for Sustainable Agriculture: New Methods to Approach Complex Traits and Target New Cultivar Ideotypes
}

\author{
Gérard Duc, ${ }^{1}$ Hesham Agrama, ${ }^{2}$ Shiying Bao, ${ }^{3}$ Jens Berger, ${ }^{4}$ Virginie Bourion, ${ }^{1}$ \\ Antonio M. De Ron, ${ }^{5}$ Cholenahalli L. L. Gowda, ${ }^{6}$ Aleksandar Mikic, ${ }^{7}$ Dominique \\ Millot, ${ }^{1}$ Karam B. Singh, ${ }^{4}$ Abebe Tullu, ${ }^{8}$ Albert Vandenberg, ${ }^{8}$ \\ Maria C. Vaz Patto, ${ }^{9}$ Thomas D. Warkentin, ${ }^{8}$ and Xuxiao Zong ${ }^{10}$ \\ ${ }^{1}$ INRA, UMR1347 Agroécologie, BP 86510, Dijon, F-21000, France \\ ${ }^{2} I I T A-Z a m b i a, 32$ Poplar Ave, Avondale, Lusaka, Zambia \\ ${ }^{3}$ Yunnan Academy of Agricultural Sciences, Kunming, China \\ ${ }^{4}$ CSIRO, University of Western Australia, Private Bag 5, Wembley, WA 6913, Australia \\ ${ }^{5}$ Biology of Agrosystems, MBG-CSIC, Pontevedra, Spain \\ ${ }^{6}$ Grain Legumes Program, ICRISAT, Hyderabad 502324, India \\ ${ }^{7}$ Institute of Field and Vegetable Crops, Novi Sad, Serbia \\ ${ }^{8}$ Crop Development Centre, University of Saskatchewan, Saskatoon, Canada \\ ${ }^{9}$ ITQB / UNL, Apart.127, 2781-901 Oeiras, Portugal \\ ${ }^{10}$ CAAS, Institute of Crop Science, Beijing, China
}

Table of Contents

I. INTRODUCTION

II. REDUCING PESTICIDE USE WITH INNOVATIVE IDEOTYPES TO ALLEVIATE BIOTIC STRESSES ........385

A. The Plant Genotype as a Component of Integrated Strategies of Protection Against Fungal Diseases to Secure Yield and Reduce Fungicide Use

B. A Diversity of Architectures and Phenologies of the Crop May Aid Competition with Weeds and Reduce Herbicide Use

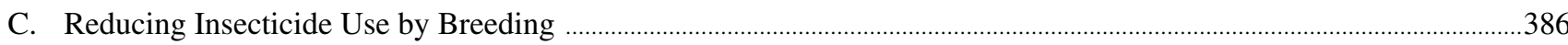

III. ADAPTATION TO NEW AREAS AND THE ASSOCIATED STRESSES ………………………………………....387

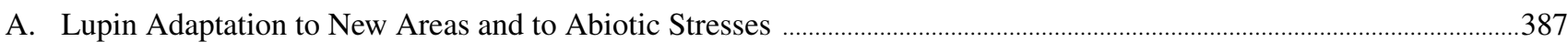

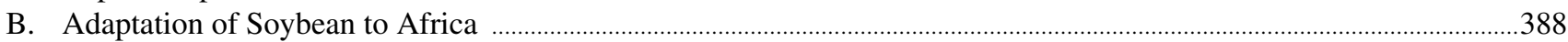

C. Common Bean Adaptation to Non-Indigenous Areas and Its Implications for Breeding ..................................................389

D. Grass Pea Genus Is Underdeveloped but Has Capacity for Adaptation to New Areas and Stresses ..............................390

E. Enlarging the Area of Cultivation of Chickpea by Increasing Its Drought Tolerance .......................................................391

F. Enlarging the Area of Cultivation of Pea, Faba Bean and Lupin by Increasing Frost Hardiness ....................................391

IV. OPTIMIZING SYMBIOTIC ACTIVITIES AND NITROGEN ACQUISITION EFFICIENCY ..................................392

A. Improving the Efficiency of the Legume-Rhizobia Symbiosis ..............................................................................................392

B. Drought Tolerance of Legume-Rhizobia Symbiosis Is Required ……………………………………….................................394

C. Improved Efficiency of the Vesicular and Arbuscular Mycorrhizal Symbiosis …………………………….............................394

Referee: Dr. Fred Muehlbauer, The Grain Legume Genetics \& Physiology Research Unit, Washington State University, Pullman, Washington, 99164, USA

Address correspondence to Gérard Duc, INRA, UMR1347 Agroécologie, BP 86510, F-21000 Dijon, France. E-mail: gerard.duc@ dijon.inra.fr

Color versions of one or more of the figures in the article can be found online at www.tandfonline.com/bpts. 
V. DIVERSITY OF CROPPING SYSTEMS AND CULTIVARS IN THE FIELD AND ON LANDSCAPES ..............394

A. Value of Genetic Resources Collection, Description and Use ..........................................................................................395

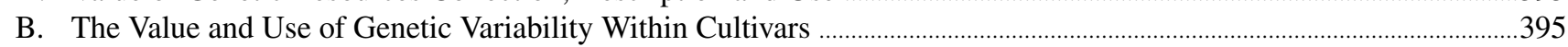

C. Towards Improved Positive Impacts of Legume Cultivars on Succeding Crops in Rotations ............................................396

D. Breeding Grain Legumes for Better Adaption to Intercropping with a Non-Legume .........................................................396

E. Breeding Annual Grain Legumes for Intercropping with Each Other …………......................................................................396

\section{THE NEED TO DEVELOP THE USE OF GRAIN LEGUMES IN HUMAN FOODS AND TO COMBINE DEMANDS OF PRODUCTIVITY BY FARMERS TOGETHER WITH PROCESSOR AND CONSUMER

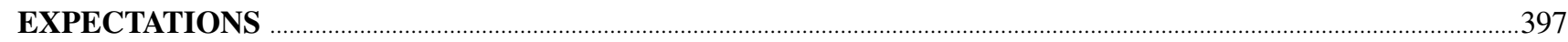

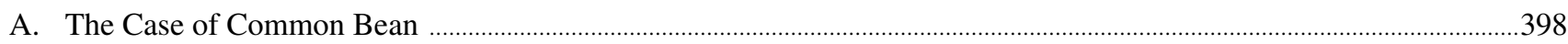

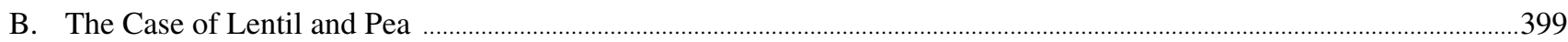

VII. USES OF ANNUAL GRAIN LEGUMES FOR FORAGE FOR A BETTER LINK WITH ANIMAL HUS-

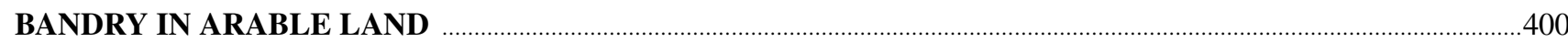

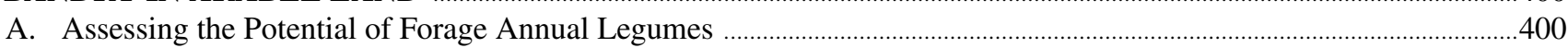

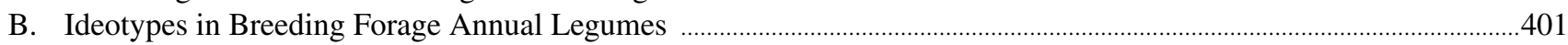

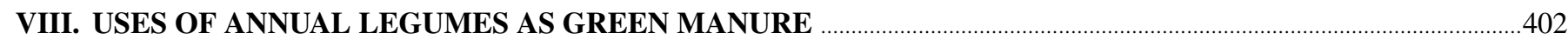

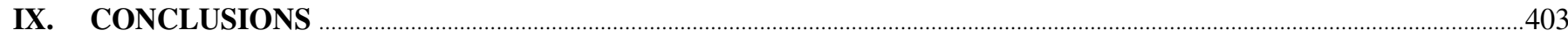

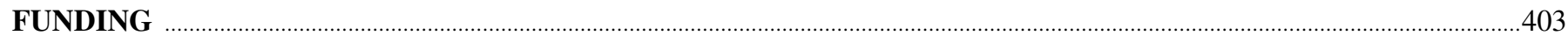

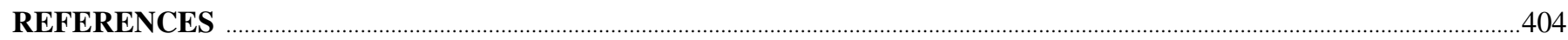

\begin{abstract}
Although yield and total biomass produced by annual legumes remain major objectives for breeders, other issues such as environment-friendly, resource use efficiency including symbiotic performance, resilient production in the context of climate change, adaptation to sustainable cropping systems (reducing leaching, greenhouse gas emissions and pesticide residues), adaptation to diverse uses (seeds for feed, food, non-food, forage or green manure) and finally new ecological services such as pollinator protection, imply the need for definition of new ideotypes and development of innovative genotypes to enhance their commercialization. Taken as a whole, this means more complex and integrated objectives for breeders. Several illustrations will be given of breeding such complex traits for different annual legume species. Genetic diversity for root development and for the ability to establish efficient symbioses with rhizobia and mycorrhiza can contribute to better resource management $(N, P$, water). Shoot architectures and phenologies can contribute to yield and biotic constraint protection (parasitic weeds, diseases or insects) reducing pesticide use. Variable maturity periods and tolerance to biotic and abiotic stresses are key features for the introduction of annual legumes to low input cropping systems and for enlarging cultivated area. Adaptation to intercropping requires adapted genotypes. Improved health and nutritional value for humans are key objectives for developing new markets. Modifying product composition often requires the development of specific cultivars and sometimes the need to break negative genetic correlations with yield. A holistic approach in legume breeding is important for defining objectives with farmers, processors and consumers. The cultivar structures are likely to be
\end{abstract}

more complex, combining genotypes, plant species and associated symbionts. New tools to build and evaluate them are important if legumes are to deliver their exciting potential in terms of agricultural productivity and sustainability as well as for feed and food.

Keywords grain legumes, breeding, ideotype, ecosystem service, food, forage

\section{INTRODUCTION}

Major annual grain legumes consisting of the oilseed legumes and pulses listed in Table 1 cover $15 \%$ of the world's arable land (FAOSTAT, 2011). They produce $c a 115$ million $t$ of protein of generally good value for animal husbandry and most grain legumes have good nutritional value and provide health benefits for humans (reviewed in British Journal of Nutrition, special issue 2012; Arnoldi et al., 2014; Vaz Patto et al., 2014). The capacity of legume species to establish a symbiosis with specific rhizobia bacteria results in biological nitrogen fixation by annual grain legumes estimated at 21.5 million $t$ per year in world agricultural systems (Herridge et al., 2008). This quantity is about a quarter of the annual $\mathrm{N}$ input with fertilizers in arable lands. Even as legumes bring these benefits of nitrogen input and diversification of cropping systems already well exploited in low input or organic agricultures, their development 
TABLE 1

Area and production for major annual grain legumes at the world and European Union levels in 2011 (FAOSTAT)

\begin{tabular}{|c|c|c|c|c|}
\hline \multirow[b]{2}{*}{2011 FAOSTAT } & \multicolumn{2}{|c|}{ World } & \multicolumn{2}{|c|}{ EU27 } \\
\hline & $\begin{array}{l}\text { production } \\
(1000 \mathrm{t})\end{array}$ & $\begin{array}{c}\text { area } \\
\text { (1000 ha) }\end{array}$ & $\begin{array}{l}\text { production } \\
(1000 \mathrm{t})\end{array}$ & $\begin{array}{c}\text { area } \\
(1000 \text { ha })\end{array}$ \\
\hline \multicolumn{5}{|l|}{ Oilseed } \\
\hline Soybean & 262038 & 103605 & 1094 & 386 \\
\hline Groundnut & 40017 & 24637 & 9 & 11 \\
\hline Common bean & 23062 & 30411 & 142 & 82 \\
\hline Chickpea & 11610 & 13181 & 45 & 46 \\
\hline Cowpea & 4952 & 10640 & 0 & 0 \\
\hline Pea & 9730 & 6141 & 1614 & 684 \\
\hline Pigeonpea & 4444 & 5863 & 0 & 0 \\
\hline Lentil & 4404 & 4172 & 51 & 59 \\
\hline TOTAL & 365580 & 202021 & 3780 & 1601 \\
\hline $\begin{array}{l}\text { annual grain legume } \\
\text { area (\% of arable land) }\end{array}$ & & 0.145 & & 0.015 \\
\hline
\end{tabular}

is heterogeneous within the world agricultural system, and in the intensive agriculture of the European Union, the competition by cereals and the low cost of fertilizers have resulted in a small proportion of arable land dedicated to grain legumes (less than 2\%). In Canada, pea (Pisum sativum L.) and lentil (Lens culinaris L.) production areas expanded from around 110 000 ha in 1981 to 1.91 million ha in 2011, accounting for about $26 \%$ of the world area seeded to these two crops. By 2012 in this country, pea and lentil area was still in progress covering about 2.3 million ha, $24.6 \%$ of the total area sown to wheat (FAOSTAT, 2012 preliminary data). The extensive land area in western Canada and the intensification of wheat-fallow rotation with grain legume crops due to removal of subsidies have been important factors in the increase in area (Miller et al., 2002).

The effect of inserting a legume in a cropping system is positive on the yield performance of successive crops. For example, according to Wright (1990) faba bean (Vicia faba L.), field pea and lentil increased cereal yield by an average of $21 \%$ in the first and $12 \%$ in the second year in northern Canadian prairies. Use of the legume reduces the $\mathrm{N}$ fertilizer inputs in a crop rotation or in an intercropping system and reduces $\mathrm{N}$ leaching risk. In a 25 year, long term, wheat-lentil rotation, wheat following lentil produced an equivalent amount of yield compared to continuous wheat, but with $40 \%$ less fertilizer applied to wheat grown after lentil (Gan, 2012). A lower $\mathrm{N}$ fertilizer use provides the benefit of a reduction in the fossil energy required for fertilizer manufacturing. It is also beneficial in lowering glasshouse gas emissions, mainly through the reduction of $\mathrm{CO}_{2}$ related to fertilizer manufacturing and to the nitrous oxide emissions by fertilized soils (Jensen et al., 2012; Jeuffroy et al., 2012). However, these advantages that have high potential to mitigate factors from climate change, are still poorly exploited in modern agriculture. In competition with cereals, the relatively lower and unstable yields of grain legumes in the context of unstable and unfavorable prices often give advantage to cereal crops. Over recent decades, investments in breeding of grain legumes (with the exception of soybean) have been lower than in cereals, which partly explains the slow pace of yield gains. Another partial explanation of the lower yield performance is based on the carbon investments that these species must use in the establishment and functioning of their symbiotic structures. If grain legumes have had minimal development in cool season agriculture, common bean (Phaseolus vulgaris L.) and especially soybean (Glycine $\max$ L.) have had tremendous development in warmer climates and irrigated zones. The high oil and protein concentrations in soybean seed brought about huge production for biofuel, feed and food uses; however, the market demand for soybean has led to deforestation of tropical zones, high water inputs, and consumption of fossil energy for the transportation of raw or end products.

The increasing demands for environment-friendly agricultural practices and for food security, especially in Europe, establish a favorable context for development of new cropping systems that include annual grain legumes while placing demands on plant breeders to produce ideotypes that meet more complex objectives. Rasmusson (1987) defined a breeder's ideotype as an ideal combination of traits in a particular genotype. 


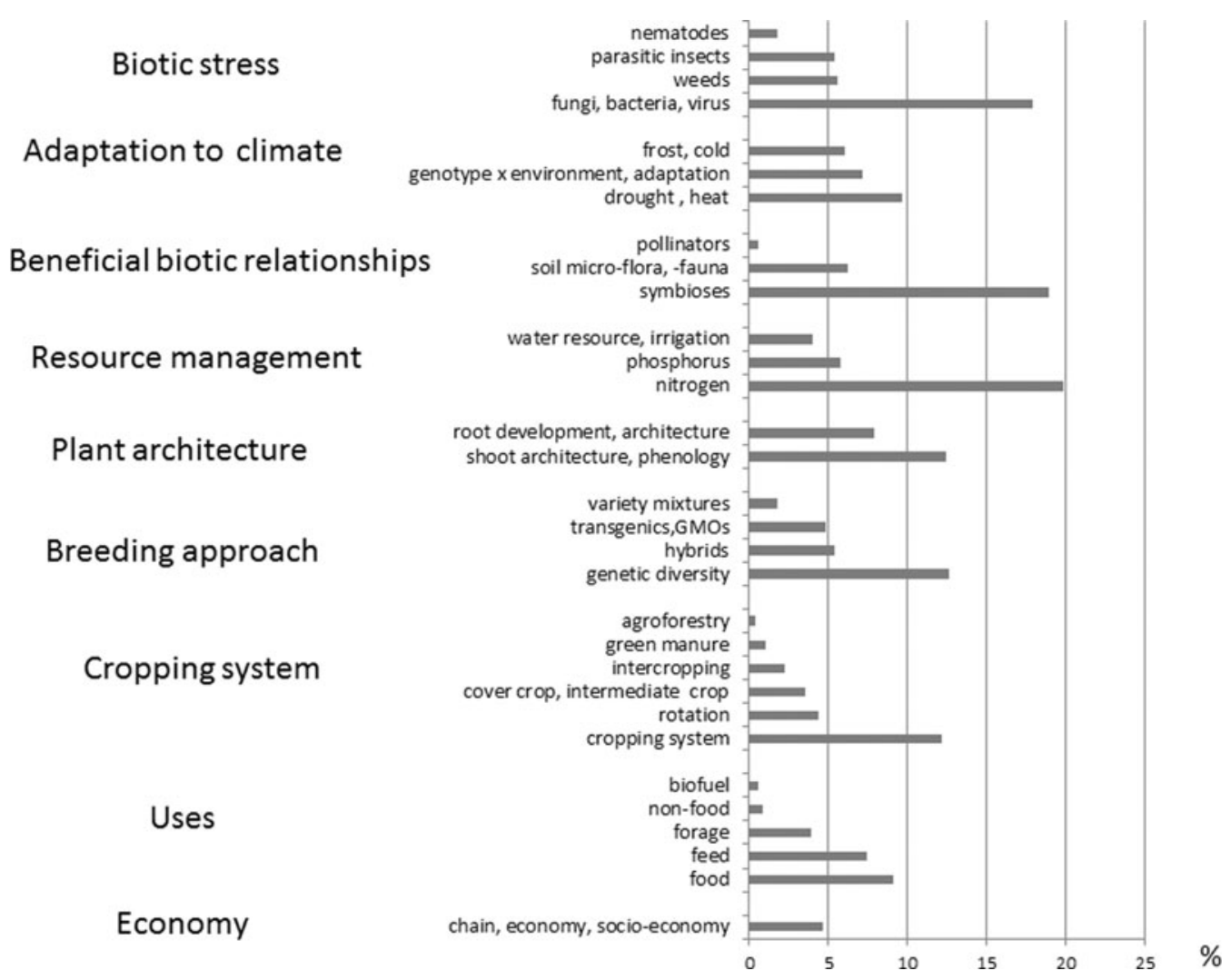

FIG. 1. Repartition (\%) of 7910 references (2008-2012) on breeding annual legumes for ecosystem services, according to the topics listed in the title or keyword list. Compiled by the authors using the data base: Web of Science. (WOS) ${ }^{\circledR}$ Thomson Reuters, international multidisciplinary citation data base, Analyse tools of "Web of Knowledge @2012 Thomson Reuters."

This target imposes more difficult multi-trait breeding with the frequent difficulty of unfavorable genetic correlations and involving trade-offs between yield, quality traits and environmental impacts. The type of cultivar is one component which can be monitored in the cropping system along with the input of water and chemicals, and the choice of species and agronomic system. The cultivar can influence productivity, the requirements for pesticides and fertilizers, and the quality and economic value of the product. Through plant cycle duration, canopy architecture, resistance to various stresses, competition for resource or crop residues, a particular genotype can find a place in diverse cropping systems for rotation, intercropping, catch crops or cover crops. Evaluation of cultivars must take into account agronomic, environmental and economic criteria and the expected impact on cropping systems over time. This is a new way of thinking about the definition of a breeder's ideotype. Cultivar evaluation will often require models to define and evaluate traits of interest. The economic and social value of a particular cropping ecosystem will have to be established and recognized by society and stakeholders in order to build a trade-off with yield objectives for a particular ideotype.

Ecosystem services and dis-services to agriculture have been classified on the basis of various supporting, provisioning, regulating and cultural services (Zhang et al., 2007). On the basis of a list of services proposed in this paper, we conducted a bibliometric analysis of worldwide publications from 2008-2012 on breeding and genetic research on major annual grain legumes (soybean, groundnut (Arachis hypogaea L.), common bean, pea, faba bean, lupin (Lupinus spp.), chickpea (Cicer arietinum L.), cowpea (Vigna unguiculata (L.) Walp), pigeonpea (Cajanus cajan (L.) millsp.), and lentil. Of 17905 references relating to genetic aspects of annual grain legumes (WOS, 21.05.2013), we identified 7910 related to ecosystem services that we classified into nine research topics (Figure 1).

This analysis reflects higher breeding investments (more than $10 \%$ of papers) were made in plant protection against diseases, in $\mathrm{N}$ acquisition and in rhizobial symbiosis which may help to reduce pesticide or $\mathrm{N}$ fertilizer inputs. It also underlines the important question of monitoring plant architecture and phenology that can impact adaptation to limiting biotic or abiotic conditions and to cropping system. In contrast with current concerns, we notice a relatively small representation of papers related to parasitic insects and weed protection, to hosting of pollinators, or to adaptation of cultivars to various cropping systems. Among potential uses, feed and food uses have received equal attention, and more than non-food uses. Among the breeding approaches, GMO cultivars, primarily developed in soybean, have raised concerns and led to studies on their environmental 
impacts, whereas the option of considering cultivar mixtures has received minor attention.

In the following sections, several cases of breeding annual grain legumes aimed at providing particular ecosystem services are presented and discussed with emphasis on describing multitrait features of targeted ideotypes.

\section{REDUCING PESTICIDE USE WITH INNOVATIVE IDEOTYPES TO ALLEVIATE BIOTIC STRESSES}

Grain legume crops have the ability of extending and diversifying crop rotations, and improving control of diseases and weeds through better crop rotations that require reduced pesticide use. On the other hand, grain legumes are new reservoirs for diverse biotic stresses. Breeding for resistance is the most economically feasible and environmentally friendly method of pest and disease control that can also contribute to yield stability (Rubiales et al., 2014). However, additional genetic sources of resistance are needed to develop new and improved disease resistant cultivars. It is also critical that the genetic basis of resistance be defined and that appropriate breeding methods are implemented. Genetic resistance of various legume species against several biotic stresses has been discovered which is often based on intrinsic resistance and escape provided by phenology and architecture. Integrated strategies using diverse resistance sources combined with cropping system strategies is important to build long term durability of biotic stress control.

\section{A. The Plant Genotype as a Component of Integrated Strategies of Protection Against Fungal Diseases to Secure Yield and Reduce Fungicide Use}

Genetic resistances of faba bean to its major fungal diseases in temperate regions, chocolate spot (Botrytis fabae (Sard.)), ascochyta blight (Ascochyta fabae (Speg.)), rust (Uromyces viciaefabae (Pers.) J.Schröt.) and downy mildew ((Peronospora viciae f. sp. fabae (Berk.) Caspary) have been identified (reviewed by Sillero et al., 2010). They can participate to fungicide spray reduction, but are incomplete resistance. Therefore, they should be combined with practices such as the crop rotation (duration and choice of non-host species), with sanitary control of certified seeds in the case of aschochyta blight, with reduction of relative humidity in the canopy (by lower sowing rate, good soil drainage, choice of plant architectures and prevention of lodging), with targeted period of sowing and of plant cycle, with prevention from nutrient deficiencies, frost damages and weed infestations (Stoddard et al., 2010). Finally, models predicting disease damage risk in relation to agronomic, cultivar and climatic data, can help to optimize and reduce fungicide doses and applications.

In the protection of chickpea from Fusarium oxysporum $\mathrm{f}$. sp. ciceris race 5 in Mediterranean-type environments, sowing date, partially resistant genotype and biocontrol agent were factors evaluated in combination and were shown respectively to reduce epidemic development, to reduce disease intensity and to increase seedling emergence (Landa et al., 2004). Seed yield and disease development was influenced by all three factors and primarily by sowing date. Chickpea ideotypes adapted to winter sowing, partially resistant to fusarium wilt and able to support the control by biological agents should be selected as one important component of integrated strategies.

Ascochyta blights are generally the most widespread and damaging diseases of grain legume crops and have been the focus of much research and resistance breeding efforts in the past 20 years. Resistance identified in various legume crops has been determined to be conferred mostly by quantitative trait loci (QTLs) (Rubiales and Fondevilla, 2012); however, disease protection, while important and useful, has generally been incomplete (Tivoli et al., 2006). Lathyrus spp. are known to be resistant to Mycosphaerella pinodes (Berk. \& Blox.) Vesterg, the causal agent of pea ascochyta blight (Gurung et al., 2002). Quantitative resistance of $L$. sativus accessions was confirmed by Skiba et al. (2004). A genetic study using a molecular approach suggested that resistance in $L$. sativus may be controlled by two independently segregating QTLs, operating in a complementary epistatic manner. The most consistent QTL detected (explaining $12 \%$ of the trait variation) showed sequence similarity to the $C f-9$ resistance gene of tomato (Skiba et al., 2004). Substantial progress has been made in the management of Ascochyta lentis on lentil, based on genetic resistance and an effective program of fungicide application (Gossen et al., 2011). In the case of chickpea, there are no strong and durable sources of resistance to A. Rabiei, but effective foliar fungicides have been identified in western Canada (Chadirasekaran et al., 2009). On the other hand, some people argue that there are useful and effective sources of resistance available for ascochyta blight control on chickpea crops, but under environmental conditions (extended cool and wet periods) favorable to disease development and spread, the resistance often breaks down. Integrated control using resistant cultivars and timely applications of fungicides is effective in many cases (Fred Muehlbauer, personal communication).

Worldwide, ascochya blight is an important foliar disease of pea (Khan et al., 2013). In combination with cultural management options consisting in rotation widening, destruction of stubbles, sowing time and model assisted decisions of fungicide application, cultivar resistance is appearing crucial to build an integrated management of this disease (Khan et al., 2013). Incremental progress has been made in accumulating minor genes for resistance in pea to Mycosphaerella pinodes through selection of diverse germplasm under conditions of moderate disease pressure. QTLs involved in partial resistance have been identified (reviewed by Khan et al., 2013), some of them colocalizing with resistance gene analogs or defense-related genes (Prioul-Gervais et al., 2007). In addition, disease severity was negatively correlated with lodging tolerance and lignification of stems, although these traits did not explain a large proportion of the variation (Banniza et al., 2005). Pea architectural traits, such as small foliar size, high stem firmness, slow canopy closure, and a small leaf area index, are unfavourable to pathogen 
development (Andrivon et al., 2013). Ideotypes defined by the pyramiding of multiple QTLs or genes for partial disease resistance and for favourable canopy architecture should be built and tested in integrated protection strategies.

\section{B. A Diversity of Architectures and Phenologies of the Crop May Aid Competition with Weeds and Reduce Herbicide Use}

The risk of weed damage varies strongly according to agricultural zones. Beside the choice of crops, cropping practices and cropping systems, the choice of cultivar is one important component of an integrated strategy. In the case of a pea study by Spies et al. (2011), branching did not differ greatly between cultivars and was not associated with weed competitiveness. The forage pea cultivars, which were leafy and had longer vines, were more competitive than semi-leafless grain cultivars (Figure 2). As a result, forage cultivars were better able to suppress weeds and maintain their yield in the presence of weeds. However, the absolute seed yield of the forage pea cultivars was low making them a poor choice for grain production. Vine length and leafy phenotype may be important genetic characteristics associated with competition in field pea cultivars; however this suggests the need to have trade-offs with lodging susceptibility.

The maturity date of legume cultivars is also an important factor affecting competitiveness with weeds (Vollman et al., 2010). In common bean studies in growth chambers and in the field, early sowing of climbing common dry bean genotypes (Type IV) had good germination and early growth competed successfully with weeds (Rodiño et al., 2006b, 2007a).

As thoroughly reviewed by Rubiales and Fernández-Aparicio (2012), the genetic lever is an important component of integrated protection from parasitic weeds, Orobanche crenata in partic-

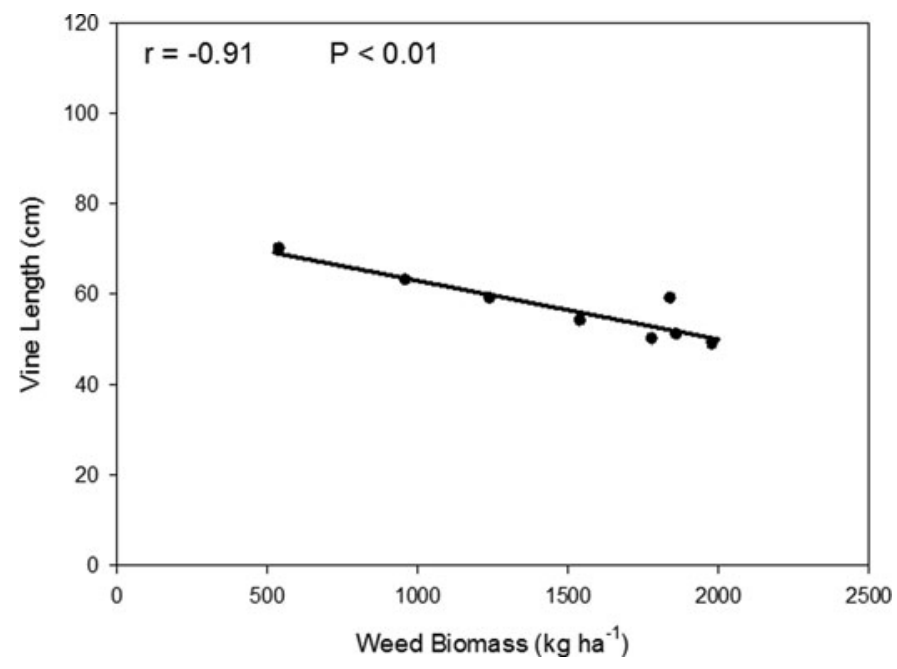

FIG. 2. A competition between weeds and crop canopy is illustrated by a negative correlation between pea vine length and weed biomass measured in Spies et al. (2011). ular, which causes severe yield losses in temperate legumes. More generally, strategies of protection, which include the cultivar ideotype, have to be adapted to the reproductive biology and physiology of weed species identified as most likely to infest.

\section{Reducing Insecticide Use by Breeding}

Worldwide, grain legume crops are attacked by many species of pest insects (nearly 60 mentionned for chickpea by Sharma et al. (2006)). Among most damaging, Weigand et al. (1994) listed leaf miner and pod borer in chickpea; sitona weevil and aphids in lentil; aphids, leaf miner and sitona weevil in faba bean; and bruchus, aphids and sitona weevil in pea. Frequent situations of diversion or of multi-legume species spectrum are observed (Clement et al., 2000), and a durable control requires very global strategies over time and land use scales. Even if sources are still scarce, genetic sources of resistance can be part of integrated control strategies in combination with cropping systems and cultural practices which help to reduce pesticide release in the environment. When resistance is not available as in the case of Aphis fabae Scopoli causing severe damages on faba bean in temperate regions, plant traits such as height, adaptation to sowing date and density can help to define ideotypes reducing insecticides inputs (Stoddard et al., 2010).

Mungbean (Vigna radiata $\mathrm{L}$.) is one of the main beans consumed in China while the bruchid (Callosobruchus clanensis L.) is a storage pest causing considerable losses to mungbean seeds. Breeding for bruchid-resistant varieties is a major goal in mungbean and other grain legume improvement (Cheng et al., 2005; Sun et al., 2007). After screening of a mungbean germplasm collection (Sun et al. 2007; Figure 3), the bruchid-immune line V2709 (introduced from AVRDC-Thailand) was identified. The resistance appeared to be determined by a single dominant gene $\mathrm{Br} 2$ anchored by molecular markers which can be used in marker assisted selection (Sun et al., 2008). Using V2709 as pro-genitor, the bruchid-resistant variety "Zhong Lv No.4" was released in 2004 in China, which does not need chemical fumigation to prevent bruchid infestation in storage.

In common bean, resistance to storage bean weevil pests (Acanthoscelides obtectus (Boh.) and Zabrotes subfasciatus (Say)) is a goal for breeders and some progress has been made by using inhibitors and antibiosis (Fory et al., 1996). Wild accessions and traditional landraces have been recently identified as important sources of resistance against bean weevils (Zaugg et al., 2013). Introgression lines and segregating populations could be used to perform QTL analysis to fine map QTLs and genes that control agronomic features related to resistance to the above-mentioned storage insect pests.

Helicoverpa armigera (Hubner) pod borer is a major pest in chickpea in the Indian subcontinent. Several germplasm accessions/breeding lines/cultivars with moderate resistance and accessions of annual and perennial wild Cicer accessions with higher levels of resistance have been identified (Sharma et al., 

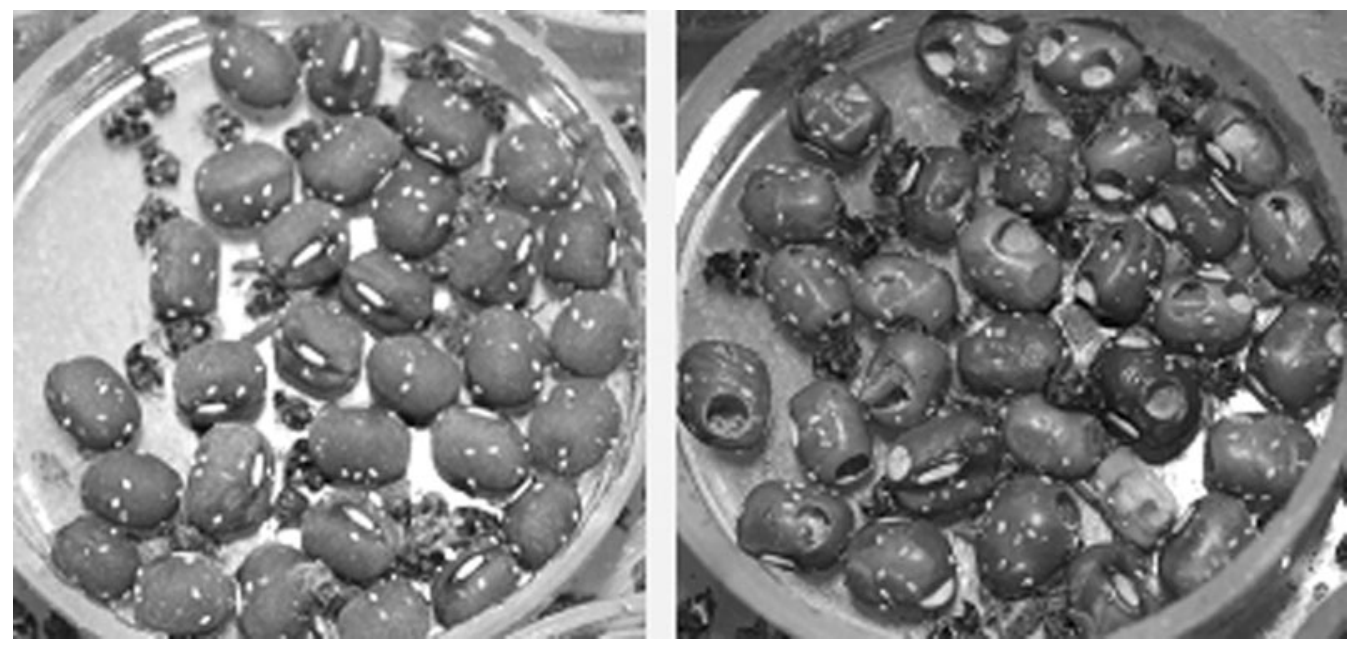

FIG. 3. Screening of mungbean (Vigna radiata L.) genetic resources for response to attack by bruchid (Callosobruchus clanensis L.) shows a resistant genotype with no insect penetration on left plate and a susceptible genotype on the right one.

2006; Dar et al., 2006) and molecular markers of resistance are under development (Sharma et al., 2006). Genetic transformants of chickpea expressing a sequence-modified Cry2Aa gene showed differential resistance to pod borer larvae, which correlated with the level of expression of the Cry2Aa protein. A high expressing line was found to confer near complete protection against the pod borer (Sumita Acharjee et al., 2010). Yadava et al. (2006) detected that spreading types were more susceptible to Helicoverpa damage than erect types. The erect plant habit is therefore a defining characteristic of a resistant ideotype.

The combination of different resistance genes or resistance mechanisms in new cultivars should provide higher durability of resistance to a given biotic stress than each gene or mechanism by itself. In the example of faba bean described by Soddard et al. (2010) sources of resistance already identified to major biotic stresses such as Orobanche crenata (Forsk.), Orobanche foetida (Poir.), Botrytis fabae (Sard.), Ascochyta fabae (Speg.), Uromyces viciae-fabae (Pers.) J. Schröt., Ditylenchus dipsaci (Kühn) Filipjef should now be combined in cultivars according to targeted agronomic zones. This approach is now more easily accessed with the development of molecular tools for genetic studies of the identified resistances (Torres et al., 2006). Some of the available molecular tools have been developed to support the establishment of resistance breeding schemes. The inclusion of resistant cultivars in rotations, with legumes as a break crop, will minimize input pesticides in arable cropping systems and improve bio-diversity in the landscape. Especially for the farmers of more marginal regions, normally characterized by reduced incomes, the use of resistant cultivars will reduce costs related to pesticides and may expand the availability of feed for animal production to foster the sustainability of these sometimes endangered farming systems.

\section{ADAPTATION TO NEW AREAS AND THE ASSOCIATED STRESSES}

There is potential for agronomic, environmental and economic value increases from the enlargement of the cultivation zone of various legume species. The introduction of exotic species in a new agricultural area and in contrasting climates raises important questions around adaptation, taking into account the requirements of tolerance to several stresses, as well as competitiveness with other indigenous crops in production and economic value. Such major works of adaptation will be described with lupin in Australia, soybean in Africa and lathyrus in dry lands. The need for yield resilience in all crops is increasing in the context of climate change that is accompanied by more frequent stress risks. Some cases of cultivar tolerance requirements to drought or freezing also reviewed by Araújo et al. (2014) will be illustrated.

\section{A. Lupin Adaptation to New Areas and to Abiotic Stresses}

Adaptation to new areas and abiotic stresses is a special challenge in narrow-leafed lupin (L. angustifolius L.). The recent domestication and subsequent development differentiates it from other grain legumes. Originally a wild Mediterranean winter annual, narrow-leafed lupin was domesticated in the nineteenth and early twentieth century as a spring-sown Central European crop in isolated breeding programs in Germany, Poland and Russia (Hondelmann, 1984). In addition to the usual domestication bottlenecks (eg. soft seededness, pod indehiscence), genetic diversity in narrow-leafed lupin was further diminished by selection for alkaloid-free 'sweet' types during the 1920s and 1930s (Hondelmann, 1984; Kurlovich, 2002; Sengbusch and Zimmermann, 1937). Subsequently, narrow-leafed lupin was further domesticated by Dr. John Gladstones in Western Australia, stabilizing pod indehiscence, introducing white flowers and seeds 
as unlinked domestication markers, and eliminating the vernalization response (cv. Unicrop, 1973) (Gladstones, 1994). Today, Western Australia dominates global production of this crop.

Breeding programs that were isolated in space and time have severely limited the genetic and adaptive diversity of both European and Australian elite material compared to their wild progenitors (Berger et al., 2012a). Moreover, this has been exacerbated by consistent selection for early phenology in both Europe and Australia, the former to facilitate timely ripening in the European summer, and the latter to accommodate drought escape in the warm, short-season, low- to mediumrainfall northern region of the Western Australian grainbelt. As a consequence, modern Australian narrow-leafed lupin cultivars are high temperature tolerant (Berger et al., 2012b), equivalent to southern Indian chickpea (Berger et al., 2011) which are grown in hotter environments using stored-soil moisture. The limited genetic diversity in lupins and extreme selection for earliness makes adaptation to new climates and abiotic stresses challenging. Australian breeders have recognized these limitations and have initiated a base-broadening program based on back/topcrossing with distantly related, genetically diverse wild germplasm, which is simultaneously increasing yield and genetic diversity (Berger et al., 2013).

In future, targeted trait introgression to improve specific adaptation to short and long season environments, grain value and farming system fit will complement this base-broadening approach. CSIRO-Australia is investigating adaptive strategies of genetically diverse wild germplasm that evolved along Mediterranean rainfall gradients in order to better understand the adaptive potential of the species (Berger et al., 2013). Information on the traits that the species uses to maximize fitness in low or high rainfall habitats, and their opportunity cost outside of that habitat will be invaluable in breeding for new habitats. For example, in targeting short season, low rainfall regions, breeders need to know whether there are strategies other than drought escape that they can employ in new cultivars. Alternatively, in higher rainfall regions, breeders must understand the opportunity cost of a conservative drought escape strategy based on early phenology. Early indications are good: adaptive strategies in wild lupin do indeed vary along rainfall gradients in an interpretable fashion. In both $L$. luteus and L. angustifolius, long-season, high-rainfall habitats select strongly for competitive traits where delayed phenology supports high above- and below-ground biomass production, high leaf area, seed yield and number, but also high water-use, and the early onset of stress (Berger and Ludwig, 2014). Conversely, lupins from terminal drought-prone environments are characterized by drought escape/avoidance (e.g. early phenology, low biomass and water use, late stress onset) that limits reproductive potential. Given that domesticated $L$. luteus and $L$. angustifolius both employ this low rainfall adaptive strategy, their potential in more productive environments is limited, as confirmed by genotype $\mathrm{x}$ environnement studies (Berger et al., 2012a, 2012b). Surprisingly, in L. luteus high rainfall ecotypes can reach lower critical leaf water potentials while maintaining higher relative leaf water contents than their lower rainfall counterparts, a drought tolerance capacity that may have evolved in response to intermittent self-imposed droughts driven by large biomass and water-use (Berger and Ludwig, 2014). These early results indicate that there is considerable unexploited adaptive potential within the genetically diverse wild lupin that remains to be introgressed into modern cultivars once the key processes are understood, and can be tracked by marker-assisted breeding.

\section{B. Adaptation of Soybean to Africa}

The recent increase in world soybean prices also influenced domestic prices in Africa, with the result that the production of soybean and other oilseeds has become more rewarding to farmers relative to other food or cash crops. A number of other factors have generated growing demands for soybeans, such as for domestic processing to meet the rising domestic demand for soybean meal primarily to supply the poultry feed industry, with prospects for edible oil. If past trends in soybean area expansion and yields continue into the future, Africa is projected to have a deficit of $196000 \mathrm{t}$ in 2020 and $450000 \mathrm{t}$ in 2030 (Abate et al., 2011). The projections show that Africa will be one of the main sources of growth in world soybean demand and this represents a significant opportunity for Africa to realize considerable foreign exchange savings through increased domestic production for import substitution. However, the growing domestic demand for soybean is unlikely to be satisfied through domestic production without major research and development investments aimed at raising the productivity, profitability, and competitiveness of smallholder soybean production. Such investments are justified because, while the bulk of soybean production in other regions comes from large-scale commercial farms that are characterized by capital intensive production methods and a high level of mechanization, smallholder farming accounts for the largest share of soybean production in Africa using labor intensive cultivation methods. Total African soybean production was 2 million $\mathrm{t}$ in 2012 and six countries in sub-Saharan Africa produced more than $91 \%$ of soybean in Africa (Figure 4). Soybean is important worldwide but with little crop development in Africa due to low yields and rhizobia inoculation requirements. The African average soybean yield is 1.2 tha $^{-1}$, compared to 2.5 t.ha $^{-1}$ at the world level. The International Institute of Tropical Agriculture (IITA-Zambia) has identified large climatic zones suitable for soybean production (Figure 5).

Efforts to develop soybean for food security of rural households can be illustrated by the rapid increase in production in Zambia from $12000 \mathrm{t}$ in 2003 to $203000 \mathrm{t}$ in 2012 (Alene et al., 2012) that is associated with breeding investments. The total number of soybean cultivars released in Africa as reported by IITA has rapidly increased from 56 in 1981-1990 to 176 in 2001-2010. Soybean breeders at IITA developed new soybean cultivars, collectively known as tropical Glycine cross (TGx), which nodulate with Bradyrhizobium spp. populations indigenous to African soils. These genotypes have been tested in some 


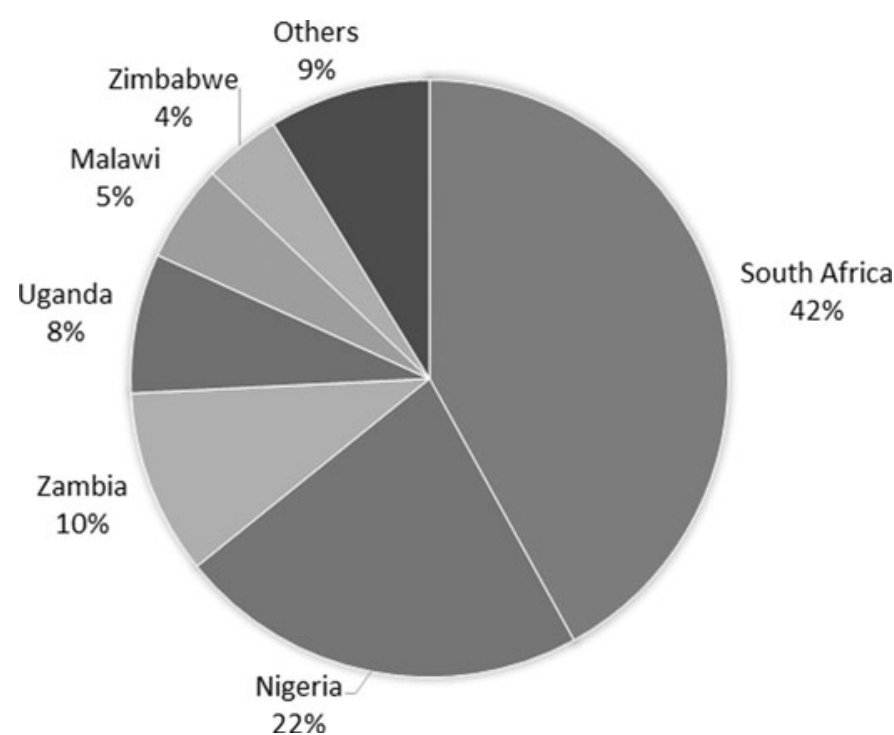

FIG. 4. Major soybean production in African countries according to FAOSTAT, 2012

parts of Africa with great success. For example, rust-resistant TGx1835-10E and TGx1987-62F have been released in Nigeria; TGx1740-2F was released in Malawi; TGx-1485-1D, TGx17402F, TGx1904-6F, TGx1908-8F, and TGx1937-1F were released in Mozambique. These were the first batch of cultivars ever released in Mozambique. SC Sirocco is a tall indeterminate soybean cultivar recommended for growing in Zambia's agro-

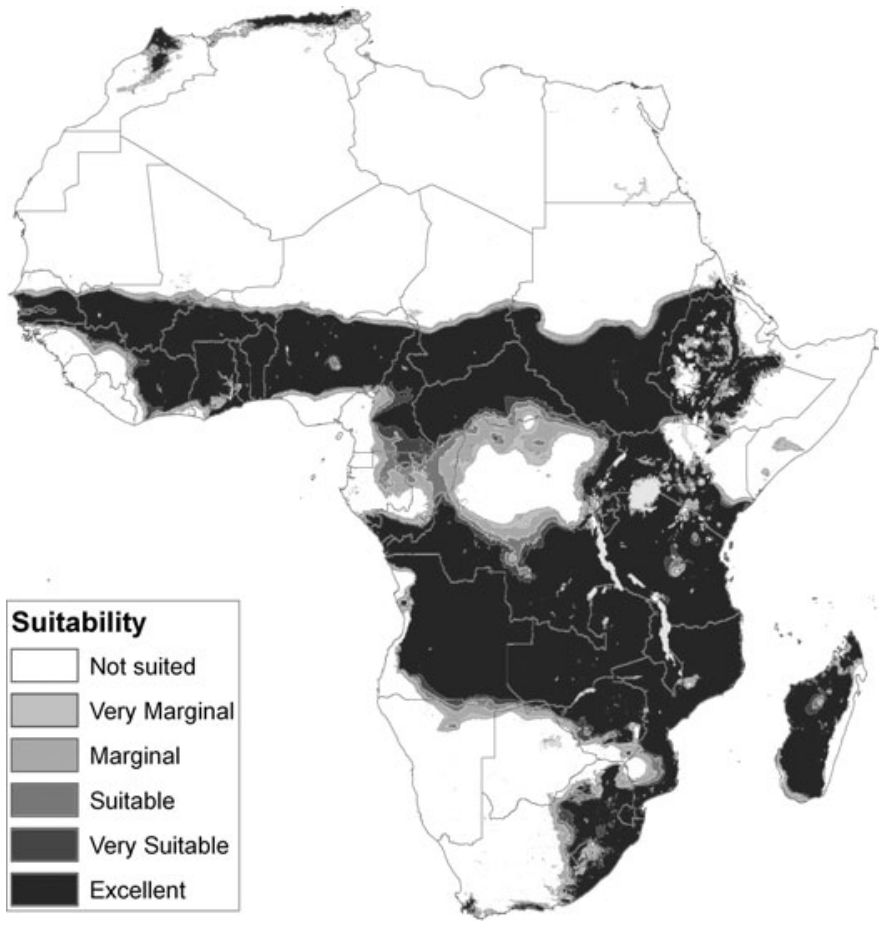

FIG. 5. African climatic zones suitable for the development of soybean production in Africa, identified by the International Institute of Tropical Agriculture. ecological Regions II and III and high potential areas of Malawi. SC Sirocco is a late maturing cultivar with a strong plant structure that provides high seed yields.

The development of improved cultivars also involved farmers' participation in selection, which made it possible for farmers to have some knowledge on performance of the lines being selected, thus facilitating rapid adoption and dissemination. With new adapted soybean cultivars, IITA aims at (1) contributing to the development of improved legume cultivars in sub-Saharan Africa and South Asia by advancing molecular breeding for traits of importance in both regions, (2) improving the livelihoods of smallholder farmers in drought-prone areas of SubSaharan Africa and South Asia through enhanced grain legume production and productivity. This project will evaluate globally the impact of newly developed cultivars in relation with the use of resources (land, water, manpower, etc.) and for the impact on the quality and security of foods.

\section{Common Bean Adaptation to Non-Indigenous Areas and Its Implications for Breeding}

No records of common bean earlier than 1543 have been found in European herbariums; however, in 1669 it was widely grown throughout Europe (Zeven, 1997). Gepts and Bliss (1988), Gil and De Ron (1992) and Escribano et al. (1994) suggested that the European bean germplasm was primarily Andean. Some limited bean germplasm exchange took place in preColumbian times between Mesoamerica and South America, but much more extensive seed movement occurred after the 1500s. Seed exchanges with Europe must have happened since the first visits of Europeans to the Americas. Common bean was introduced into the Iberian Peninsula (Spain and Portugal) mainly from Central America around 1506 (Ortwin-Sauer, 1966) and from the southern Andes after 1532, through sailors and traders who brought the nicely colored, easily transportable seeds with them as a curiosity (Brücher and Brücher, 1976; Debouck and Smartt, 1995). The principal cultivated bean types in the Iberian Peninsula are large-seeded white and coloured cultivars of Andean origin that belong to the white-kidney, canellini, marrow, "Favada", large cranberry, cranberry, red-pinto and "Canela" market classes, and the medium-seeded white and coloured cultivars of Mesoamerican origin that correspond to the great northern and pinto market classes (Santalla et al., 2001a).

The common bean landraces grown in the Iberian Peninsula suggest interesting questions about the nature of the variation observed, as well as the evolutionary forces affecting the current European common bean germplasm. The Mesoamerican beans arriving in the Iberian Peninsula probably displayed limited genetic variation, represented by a small population size (population bottlenecks), and further establishment of new populations were based on a few individuals (founding events) based on farmer's preferences, that could have increased genetic drift. However, later germplasm introductions from the southern Andes after around 1532, principally from Peru, could have broadened the genetic diversity (Brücher and Brücher, 1976). 
Occasional outcrossing, adaptation to particular environmental conditions (for temperature, moisture, photoperiod, soil fertility, diseases, and insects), cropping systems and strong selection for consumer preferences for seed types, might have played a significant role in the evolution of new variation in common bean in the Iberian Peninsula. Thus, new germplasm (e.g., "Favada", hook and large-great-northern class cultivars, Santalla et al., 2001a) that could be considered as "Iberian forms," could have emerged from initial recombination events between the Mesoamerican and Andean gene pools that are better adapted to the conditions prevailing on the Iberian Peninsula. The new Iberian forms could have subsequently been disseminated to other parts of Europe, thus contributing to much-wider variation observed in European germplasm (Lioi, 1989; Gil and Ron, 1992; Escribano et al., 1994; Limongelli et al., 1996; Zeven, 1997; González et al., 2006). Hence, the Iberian Peninsula, mainly the north and northwest regions, could be considered as a secondary center of genetic diversity for the common bean, especially regarding the large white-seeded market class cultivars (Santalla et al., 2002; Rodiño et al., 2006).

The secondary diversification of the common bean in Europe and the arising of new recombinant forms between the Andean and Mesoamerican genetic pools opens the door for new opportunities for breeding. In fact, there are constraints to the crosses between Mesoamerican and Andean germplasm due to genetic barriers, such as the $D L$ gene. Gonzalez et al. (2009) reported successful interrracial and interpool crosses as a basis for the development of new common bean varieties in Europe. Since the Mesoamerican germplasm displayed more resistance to pathogens and some Andean varieties had very high seed quality, the use of the European recombinant germplasm as "bridge parents" in interpool crosses to overcome the interpool genetic barriers provides, an opportunity for introgression of relevant genes in the common bean varieties currently grown in Europe.

The fact that the common bean has evolved wordlwide outside its areas of origin has implications for the development of new varieties in its areas of adaptive radiation, such as Europe. For the rhizobia symbiotic system, it is possible that migration of species had not been parallel, so additional efforts are under way to achieve efficient symbiotic genotypes of common bean and rhizobia (Rodiño et al., 2010; Rodiño et al., 2011).

Moreover, the common bean originated and was domesticated in tropical highlands. This means that abiotic conditions such as water availability and temperature range have had an influence on the development of European varieties (Rodiño et al., 2006; Rodiño et al., 2007b; Riveiro, 2012). Finally, the point of disease resistance in common bean is crucial to adapt this species to new zones. The most important diseases that constrain common bean production worldwide, and particularly in Europe, are anthracnose (caused by Colletotrichum lindemuthianum), rust (caused by Uromyces appendiculatus), common bacterial blight (caused by Xanthomonas axonopodis pv. phaseoli), halo blight (caused by Pseudomonas syringae pv. phaseolicola), bean common mosaic virus and bean common mosaic necrosis virus (Monteagudo et al., 2006). Some pathogens including those causing anthrancose (Pastor-Corrales et al., 1995) and rust (Sandlin et al., 1999) have co-evolved with common bean, thereby forming distinct Andean and Middle American populations. Disease resistance tends to concentrate in germplasm from specific areas and therefore the core collections facilitate the identification of the geographic distribution of favourable genes imparting resistance to major diseases (Simon and Hannan, 1995).

One of the current common bean breeding efforts in Europe is the improvement of resistance to several pathogens. Wild accessions and traditional landraces have been recently identified as important sources of resistance against rust and powdery mildew (Leitão et al., 2013), or against anthracnose, rust, bacterial blight and bean common mosaic virus (Rodiño et al., 2009). In particular the inheritance of common bean anthracnose resistance has been intensely studied (Geffroy et al., 2008; Campa et al., 2011) and resistance breeding has lately included anthracnose and potyvirus resistance into the common bean market class, fabada (Ferreira et al., 2012). For powdery mildew, resistance controlled by single genes has also been recently described (Trabanco et al., 2012; Pérez-Vega et al., 2013).

\section{Grass Pea Genus Is Underdeveloped but Has Capacity for Adaptation to New Areas and Stresses}

The grass pea genus (Lathyrus spp.) is large (Allkin et al., 1986). However, only one species, Lathyrus sativus L. is widely cultivated as a food crop, while other species are cultivated to a lesser extent for both feed (grain and forage) and food. These species include $L$. cicera L., L. clymenum L., L. ochrus L., $L$. tingitanus L., L. latifolius L. and L. sylvestris L. Kislev (1989) suggested that $L$. sativus is perhaps the first crop domesticated in Europe, around $6000 \mathrm{BC}$, as a consequence of expansion of agriculture from the Near East.

Globally, the area under grass pea is estimated at 1.5 million ha with annual production of 1.2 million $t$, mainly in South Asia and Sub-Saharan Africa (Kumar et al., 2011). It is an annual legume crop with high protein content, which normally ranges from 26 to $28 \%$, but can be as high as $32 \%$ (Campbell, 1997). It can fix large amounts of nitrogen, and has a high degree of resistance to abiotic and biotic stresses (Vaz Patto et al., 2011). Grass pea is endowed with many properties that combine to make it an attractive crop in more marginal, droughtstricken, rain-fed areas where soil quality is poor and extreme environmental conditions prevail (Vaz Patto et al., 2006a). It is a dual purpose crop with great agronomic potential as a grain and forage legume.

Grass pea provides an opportunity to diversify existing cereal-based cropping systems, to manage the risk of unpredictable weather and increase the profitability and sustainability of agriculture under climate change scenarios, especially on marginal land. It is rightly considered one of the most promising sources of calories and protein for the vast and expanding 
populations of drought-prone and marginal areas of Asia and Africa (Vaz Patto et al., 2006a). Due to its relatively low input requirements compared to major crops, grass pea is considered a model crop for sustainable agriculture and as an interesting alternative for cropping systems diversification in marginal lands in Europe, Australia and America (Almeida et al., 2014; Vaz Patto et al., 2006a).

Considerable genetic variation exists among grass pea accessions, especially in morphological vegetative characters that can be used in the development of specific and dual purpose cultivars. However, little attention has been given to this crop, particularly by scientists in developed countries (Campbell, 1997). As expressed by Smartt (1984) it is rather puzzling that a crop which has been used as a pulse for at least 8000 years, should have made so little evolutionary progress as a grain crop during this time. He considers that the lack of progress as a pulse crop might have been due to its use as a forage crop. Although there are relatively few efforts throughout the world to genetically improve grass pea, some important programs exist that aim to improve its yield, resistance to biotic stresses (FernándezAparicio et al., 2009a, 2012; Vaz Patto et al., 2006b, 2009; Vaz Patto and Rubiales, 2009), and most importantly, to reduce concentrations, or ideally eliminate, an anti-nutritional factor from the seed, i.e., the neurotoxin Beta-oxalyl-diaminopropionic acid (ODAP) (Vaz Patto et al., 2006a).

One factor that will render impossible the future cultivation of grass pea in several Mediterranean regions is the lack of resistance to Orobanche species (Robertson and Abd El Moneim, 1996). It was recently concluded that the combination of different avoidance and resistance mechanisms, both acting at different phases of the infection process, seemed to reduce infection under field conditions in L. cicera and L. sativus (FernándezAparicio et al., 2009a, 2012). This interesting germplasm when integrated in adequate cropping system and cultural practices may represent the first steps for an effective way to reduce damage from parasitic weeds (Rubiales and Fernandez-Aparicio, 2012).

In addition to drought tolerance, grass pea is also tolerant to excessive rainfall and can be grown on land subject to flooding (Kaul et al., 1986; Campbell et al., 1994). This is exploited in South Asia where its seeds are broadcast into standing rice crops (Abd El Moneim et al., 2001). Its capacity to withstand moderate salinity has been recognized (Campbell et al., 1994; Haque et al., 1996). It has a very hardy root system with good penetrating abilities, and therefore can grow on a wide range of soil types, including very poor soil and heavy clays (Campbell, 1997). L. sativus has been reported to be tolerant to a deficiency in essential nutrients and able to store large amounts of lead in its root tissues (Brunet et al., 2008). Therefore, L. sativus could be used for the development of new rhizofiltration systems. L. sativus accessions are generally very susceptible to cold, whereas resistance is frequently found in $L$. cicera accessions (Robertson and Abd El-Moneim, 1996). Tolerance to cold has also been reported in a Portuguese accession of L. ochrus (Abd
El-Moneim and Cocks, 1993). Nevertheless, the knowledge of the physiological mechanisms underlying this resistance to environmental stresses is missing. Efficient and discriminating methods for drought and salt resistance screening have recently been developed in Lathyrus spp. (Talukdar, 2011; Silvestre et al., 2014). Using these screening methodologies, several L. sativus resistant genotypes have been reliably and efficiently identified.

\section{E. Enlarging the Area of Cultivation of Chickpea by Increasing Its Drought Tolerance}

Terminal drought is a major constraint to chickpea productivity. Drought tolerance is a complex trait and Rehman et al. (2011) identified multiple QTLs associated with traits affecting grain yield under terminal drought stress. A high harvest index (seed/total plant biomass) is associated with a high drought tolerance. Traits of early flowering, podding and maturity provide an escape mechanism. Higher stomatal conductance and cooler canopies were associated with higher grain yield under stress and these traits may provide indirect selection criterion.

A prolific root system contributes positively to grain yield under terminal drought conditions. A genomic region controlling root traits (root length density and total root biomass) and other traits related to drought tolerance was introgressed from drought tolerant genotypes (Gaur et al., 2008; Vadez et al., 2012). Several progenies with significantly higher yield were identified and are in multi-location tests before their release to farmers for cultivation.

\section{F. Enlarging the Area of Cultivation of Pea, Faba Bean and Lupin by Increasing Frost Hardiness}

In Europe, autumn sown cultivars represent an interesting complement to spring pea, faba bean and lupin, the most widely cultivated grain legumes. Autumn sown cultivars would allow the enlargement of the cultivated zone towards more continental climates and also provide an escape from frequent drought during the reproductive period. In Southwest China, frost hardiness would allow cultivation at higher altitudes. These goals require the development of winter hardy cultivars with a high level of resistance to freezing and slow dehardening, which may allow development of new and valuable cropping systems (Vocanson and Jeuffroy, 2007).

In pea, faba bean and white lupin, germplasm with improved frost hardiness has been detected in genetic resource collections (Etévé, 1985; Picard et Duc, 1986; Huyghe, 1991) and were used to breed resistant cultivars adapted to France. In pea, an ideotype of winter pea is being designed (Hanocq et al., 2009) which combines (i) the day length flowering response gene $\mathrm{Hr}$, providing an escape from frost injury (Lejeune et al., 2007), (ii) early flowering alleles at the $L f$ locus (Foucher et al., 2003), (iii) QTLs of Mycosphaerella pinodes and Aphanomyces euteiches resistance (Prioul-Gervais et al., 2007; Pilet-Nayel et al., 2005), and (iv) high protein and low trypsin inhibitors in seeds (Burstin et al., 2007; Gabriel et al., 2008). The 
pyramiding of genes and QTLs involved in this ideotype is underway at INRA-France using marker-assisted selection.

We have illustrated various strategies of diversification and enlargement of adaptive capacities of cultivars which can enlarge the cultivated area, generate a diversification of cropping systems and of uses. It requires for the breeder (i) a detailed characterization of the environments and of their limiting factors, and (i) an optimized definition of locations and agronomic practices in the trial network in order to exploit positive genotype $\mathrm{x}$ environment interactions.

\section{OPTIMIZING SYMBIOTIC ACTIVITIES AND NITROGEN ACQUISITION EFFICIENCY}

Even if the capacity to establish a symbiosis with rhizobia is a general and valuable feature of cultivated grain legumes in reducing $\mathrm{N}$ fertilizer requirements, the efficiency of the symbiosis to fix $\mathrm{N}_{2}$ is crucial for plant growth, but displays variations due to environment and to plant and bacteria genotypes (Peix et al., 2014; Courty et al., 2014). Estimations of the quantity of N derived from fixation vary greatly according to species, experiment and methodology of measurement, as reviewed by Unkovich and Pate (2000). Upper values between 240 and $450 \mathrm{~kg}^{-h^{-1}}$ of $\mathrm{N}$ fixed in shoots were reported for soybean, lupin, field pea, faba bean, and between 140 and $190 \mathrm{~kg} \cdot \mathrm{ha}^{-1}$ for common bean, lentil and chickpea. These performances correspond to percentages of nitrogen derived from atmosphere (\% Ndfa) often higher than $70 \%$. Plant genetic variability for $\% \mathrm{Ndfa}$ has been detected in many legume species. In a collection of faba bean genetic resources for example, Duc et al. (1987) measured a range of $\mathrm{Ndfa}(50$ to $80 \%$ ) that positively correlated with seed yield. This major symbiotic pathway of $\mathrm{N}$ acquisition in legume plants is complemented by the assimilation pathway of mineral forms of $\mathrm{N}$ derived from soil or fertilizers. The efficiency of the symbiotic pathway for accumulating $\mathrm{N}$ and for the plant to store it as proteins of good nutritional value, is the ultimate goal of most breeding programs. These traits are very integrative and quantitative, and are based on several plant functions and numerous plant genes, together with environmental factors (Santalla et al., 2001b; Rodiño et al., 2011).

\section{A. Improving the Efficiency of the Legume-Rhizobia Symbiosis}

As a result of plant-rhizobia co-evolution, a spectrum of compatible rhizobia spp. has developped, each specific for one or more given legume species. When indigenous compatible populations are present in a soil, a single legume plant is usually colonized by a diversity of strain genotypes (Denison, 2000), with very frequent situations of single strain occupancy in each nodule. The rhizobial strain can modulate the efficiency of $\mathrm{N}_{2}$ fixation and significant plant-bacterial strain interaction effects on efficiency to fix $\mathrm{N}_{2}$ have been reported, as in the case of pea (Laguerre et al., 2007; Depret and Laguerre, 2008). A field experiment conducted in a soil containing indigenous rhizobia has shown that each nodule in a pea plant is occupied by a single

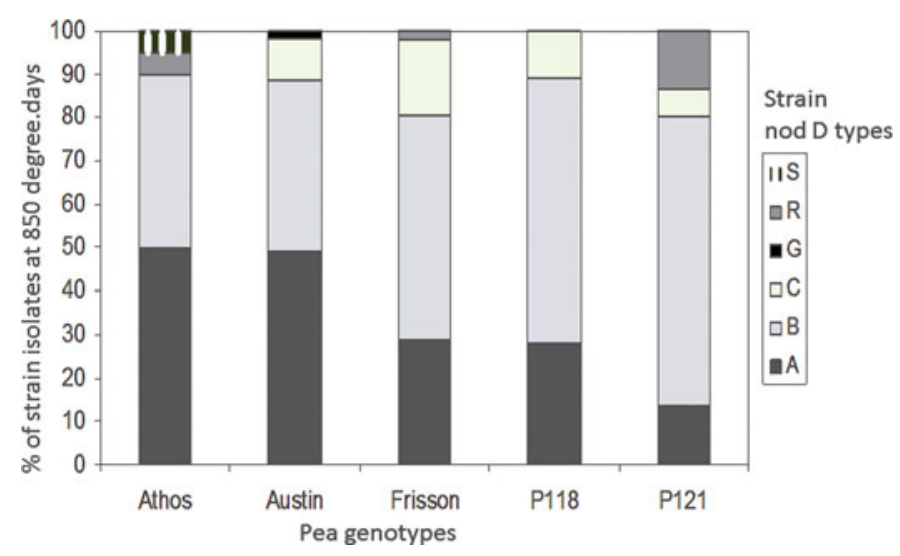

FIG. 6. In a field experiment, percentage of nodule occupancy by Rhizobium leguminosarum bv viciae strains characterized by their nod D gene type (A, B, C, G, R or S) on five pea genotypes (cv Athos, cv Austin, cv Frisson, P118, P121) (Bourion et al., 2007; Laguerre et al., 2007).

rhizobia strain and the plant genotype influences the frequency of nodule occupation by various strains (Bourion et al., 2007; Laguerre et al., 2007) (Figure 6). Therefore, we can hypothesize that the ability of a given plant genotype to select particular strains is one element of the definition of an ideotype.

Exploiting favorable interactions through the inoculation of cultivars is often limited by existing indigenous rhizobia strains in soils. Incorporating genes that determine specific mechanisms of recognition as those already identified in pea into specific cultivars, is an option to monitor specific cultivar $\mathrm{x}$ strain combinations (Lie, 1984; Devine and Breithaupt, 1980; Sagan et al., 1993).

The plant genotype itself is a major determinant of an efficient symbiosis. Nodulation is under a plant polygenic control (Olroyd and Downie, 2008) and it is regulated primarily via a systemic mechanism known as autoregulation of nodulation (AON). Genes and mechanisms of AON have been reviewed by Reid et al. (2011). Deregulated mutants have been obtained in several grain or forage legume species that express a hypernodulated (Nod++) phenotype (Reid et al, 2011). In hypernodulated pea mutants (Sagan et al., 1996), even if protein content in seeds is high, shoot growth is reduced. A yield depression has been observed in these mutants, which may be explained by higher $\mathrm{C}$ costs for the establishment and functioning of nodule structures (Salon et al. 2001), and possibly also by a reduced root development which was demonstrated in some Nod++ mutants of the model legumes Medicago truncatula (Gaertn) and Lotus japonicus (Regel) Larsen (Schnabel et al., 2011; Krussel et al., 2002; 2011).

Genetic variability for root architecture has been reported in pea (McPhee, 2005; Bourion et al., 2007; Figure 7), lentil (Gahoonia et al., 2005) and chickpea (Gaur et al., 2008). The development of root traits that support symbiosis and also water and nutrient acquisition, are important elements of the ideotype definition to reduce limiting factors. Efficiency and kinetics of $\mathrm{N}$ fixation and assimilation pathways are other important 


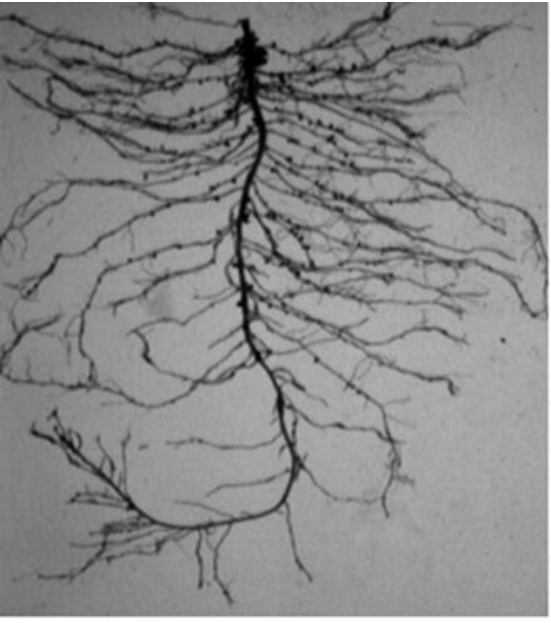

Frisson

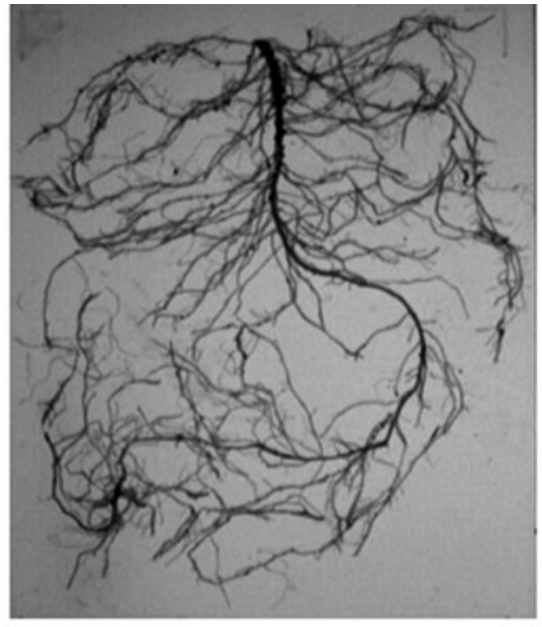

Pea line with long lateral roots

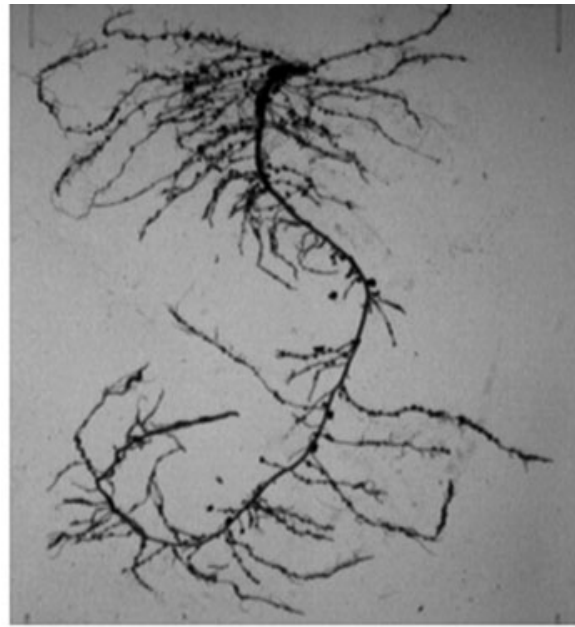

Hyper-nodulated pea line

FIG. 7. A variability in root architecture in pea illustrated on three genotypes (cv Frisson and two breeding lines) (Bourion et al., 2007).

parameters, especially in relation to the expected risks of stress during the growing period. In early stages of plant development, before nodules start to fix, and at late stages of development when nodules are senescing, the ability of the plant to use soil mineral nitrogen is beneficial to the plant. Figure 8 illustrates differences between five genotypes under study for the respective contribution of the assimilation and fixation pathways along plant development (Bourion et al., 2007).

There have been a few QTL studies on genetic determinants for nodule traits, mainly for nodule number per plant, and to a lesser extent, for nodule biomass and nodule area (Nodari et al., 1993; Souza et al., 2000; Nicolás et al., 2006; Bourion et al., 2010). Bourion et al. (2010) identified nine different genomic regions controlling nodule development and growth on pea (Figure 9). Interestingly, they observed a positive relationship between nodule establishment and root growth, suggesting that it may be possible to develop plant genotypes with both (1) a larger root area to increase the surface of exchange between roots and soil and (2) a high number of nodules. They estimated the part of $\mathrm{N}$ derived from symbiotic fixation (NDFA), and nodule efficiency calculated as fixed N2 per unit nodule biomass. For these traits, three and two QTLs were found, respectively. QTLs for both positively correlated variables co-localized, resulting in three genomic regions controlling the efficiency of fixation. The multigenic control of symbiosis was well illustrated in this study where QTLs for symbiosis were found at six genomic regions. Genetic correlations and co-localisation of QTLs underlined the importance of nodule and root development to build plant
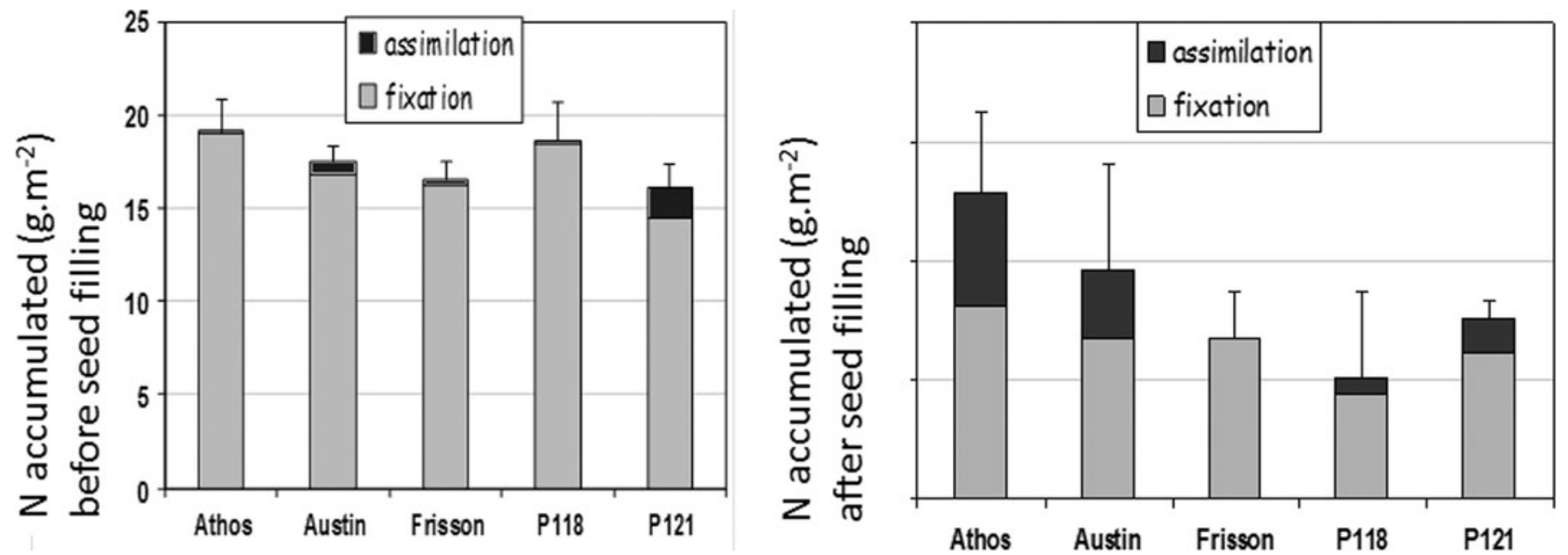

FIG. 8. Variability among five spring pea genotypes (cv Athos, cv Austin, cv Frisson, P118, P121) for the quantities of stored nitrogen in shoots issued from either nitrogen fixation or assimilation, before seed filling or between seed filling and maturity (Bourion et al., 2007). 


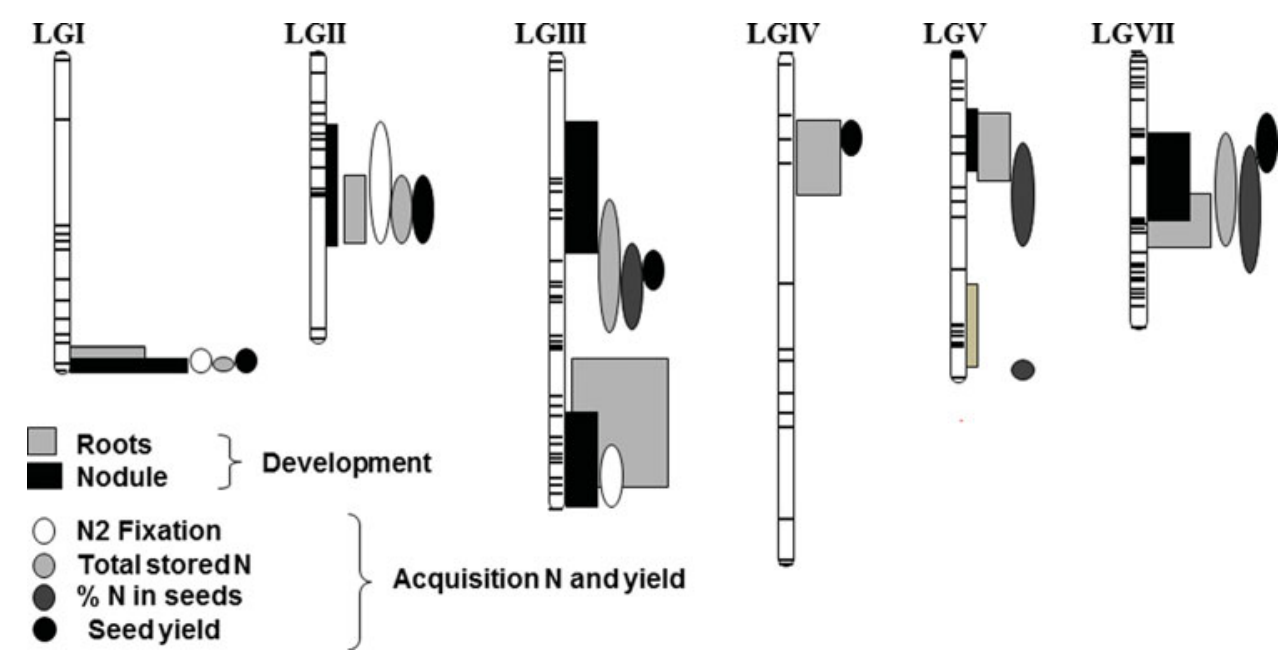

FIG. 9. QTL regions detected on seven linkage goups of the pea genome involved in root and nodule development, in $\mathrm{N}$ acquisition, or $\mathrm{N}$ storage in seeds (Bourion et al., 2010).

ideotypes with high $\mathrm{N}$ accumulation. Physiological mechanisms involved in root growth or architecture adaptation to mineral $\mathrm{N}$ availability or to abiotic stresses has been little studied in legumes, and some candidate genes involved in soil nitrogen sensing, salt adaptation and further regulation pathways have recently been proposed (Zahaf et al., 2012; Mohd-Radzman et al, 2013; Bourion et al., 2014).

\section{B. Drought Tolerance of Legume-Rhizobia Symbiosis Is Required}

Drought stress is a major factor limiting symbiotic $\mathrm{N}$ fixation in all legume crops. Results on drought stressed soybean plants (Gil-Quintana et al., 2013) suggested that plant carbon metabolism, protein synthesis, amino acid metabolism, and cell growth are among the processes most altered in soybean nodules under stress. The results support the hypothesis of a local regulation of $\mathrm{N}$ fixation taking place in soybean and downplaying the role of ureides in its inhibition. In the common bean - rhizobia symbiotic system, Riveiro et al. (2012) have shown that local rhizobia strains play a role in protection from drought stress. The existence of genetic variation in $\mathrm{N}$ fixation response to water deficit among common bean cultivars and rhizobia strains opens a real possibility that adequate performance can be obtained from bean genotypes and rhizobia strain selections in dry environments.

\section{Improved Efficiency of the Vesicular and Arbuscular Mycorrhizal Symbiosis}

With the exception of Lupinus spp., most cultivated legumes establish a symbiosis with vesicular and arbuscular mycorrhizae (VAM), which contributes to $\mathrm{P}$ and water acquisition, wellestablished yield factors (Auger, 2001). Synergies have already been demonstrated for legume plant productivity between $\mathrm{N}$ and $\mathrm{P}$ acquisition pathways, with positive interactions between symbioses with rhizobia on the one hand and VAM on the other
(Toro et al. 1998). Common genes have been identified which play a role in the regulation of both symbioses (Duc et al., 1989; Morandi et al., 2000; Zhu et al., 2006). Plant genes involved in VAM symbiosis are being progressively discovered and the role of the strigolactone synthesis gene has been demonstrated in pea (Gomez-Roldan et al., 2008). A genome-wide analysis conducted on defined cell types of Medicago truncatula roots has identified VAM-activated plant genes during both early and late stages of VAM development (Hogekamp and Küster, 2013).

In parallel to the genetic variability identified for $\mathrm{N}$ acquisition and establishment of rhizobial symbiosis, genetic variability has been reported for $\mathrm{P}$ acquisition and breeding strategies for the improvement of this trait have been proposed (Ramaekers et al., 2010). We suggest to explore genetic resources and to target breeding work towards an ideotype with large root development, with good ability to host efficient rhizobial and VAM strains, and with optimised $\mathrm{N}$ and $\mathrm{P}$ acquisition. Such cultivars should be desirable, especially in conditions of low input agricultures and drought stress risk.

As reviewed by Zancarini et al. (2013), the existing genetic variability for root development and for production of root exudates are important traits that breeders should consider in the near future in their ideotype definitions, for positive interactions with total soil microflora, which reciprocally can impact plant yield and health.

\section{DIVERSITY OF CROPPING SYSTEMS AND CULTIVARS IN THE FIELD AND ON LANDSCAPES}

The existing genetic variability in legume genetic resource collections for architecture, phenology, cycle duration and stress tolerance, offers many new possibilities for breeding and for application of grain legumes to diversified cropping systems. 


\section{A. Value of Genetic Resources Collection, Description and Use}

Reduction from numerous cultivated landraces to fewer high yielding cultivars imposed by modern breeding strategies and selection procedures, and during domestication, is reducing plant genetic diversity. With changing climate and greater ecosystem instability, the genetic base for breeding needs to be diversified. Released cultivars may be increasingly genetically vulnerable and growers may be faced with increased risk. This situation has prompted breeders to aggressively explore distantly related species for useful traits, such as disease resistance, early maturity, stiff stems for upright growth, high or low temperature tolerance, and adaptability to photoperiod. The richest sources of novel variation reside in landraces and/or wild species when available (Ellis et al., 2011; Redden et al., 2011; Updayada et al., 2011; Smykal et al., 2014).

The genus Lens is used as an example of the possibilities in the use of genetic resources. The genus comprises seven taxa in four species: L. culinaris with subspecies (culinaris, orientalis, tomentosus and odemensis), L. ervoides (Brign.) Grande, L. nigricans (M. Bieb.) Godron and L. lamottei Czefr. Evaluation of the world collection of wild Lens species identified sources of resistance to Colletotrichum truncatum and Ascochyta lentis. Resistance to race 0 of $C$. truncatum and to A. lentis is more frequent in L. ervoides, followed by L. nigricans and L. lamottei (Tullu et al., 2006, 2010). Stemphylium blight (Stemphylium botryosum) resistance is also prominent in L. lamottei followed by L. ervoides accessions (Podder et al., 2013). Resistance to Orobance crenata has also been described in Lens spp. (Fernández-Aparicio et al., 2009b). The initial crosses of $L$. culinaris with $L$. ervoides were made using embryo rescue, indicating that intra- specific populations, when available, can lead to broad exploitation of genetic variation within the wild species. For example, higher levels of resistance to anthracnose were introgressed into cultivated lentil breeding material through hybridization with L. ervoides (Fiala et al., 2009; Vail and Vandenberg, 2010). Crosses of L. culinaris ssp. culinaris with L.c. ssp. odemensis, L.c. ssp. tomentosus and L. ervoides showed recombinants with higher yield, biomass, and possibly other quality traits (unpublished data). Strong emphasis on using disease resistance genes continues, and a wide range of agronomic and quality characteristics were shown to be available in L. ervoides.

Wild species of the genus Lens are an important source of genetic variation for breeding lentil cultivars adaptable to new environments and tolerant of biotic and abiotic stresses. In previous studies, attempts were made to develop interspecific hybrids through direct regeneration of plantlets by in vitro culturing of young embryos. In most cases, insufficient numbers of seeds were produced for genetic studies. Like most pulse crops, lentils are recalcitrant to regeneration. Production of double haploid plants is difficult and attempts to produce double haploid lines for lentil from androgenesis microspore culture approaches did not succeed to date (M. Lulsdorf, pers. com.). Induction of in vitro root growth after embryo rescue is more problematic in lentil than in pea and chickpea (Williams and McHughen, 1986). Gulati et al. (2001) reported a success rate of $84-96 \%$ with a micro-grafting of in vitro regenerated shoots from cotyledonary nodes compared to a much lower efficiency obtained with in vitro root induction. The grafting technique has been adapted for many applications (Yuan et al., 2011; Gurusamy et al., 2012) in rescuing genotypes, physiological studies and gene function studies.

Many of the technical and biological barriers to the use of genetic resources from wild species in lentil breeding are being overcome. The next phase will be the systematic introgression of genes from wild to cultivated lentil using new technologies of genomic analysis that will allow gene tracking. With accompanying phenotypic analyses, it should be possible for breeders to use a much wider range of genetic diversity to tailor the adaptation of future lentil cultivars to more diverse agricultural ecosystems.

\section{B. The Value and Use of Genetic Variability Within Cultivars}

Among major cultivated grain legumes, pigeon pea and faba bean are considered as the most cross-pollinated crops with levels of outcrossing higher than $25 \%$. This prompted the development of synthetics, populations and hybrid cultivars that incorporate the richness of allelic diversity. This diversity based on the heterogeneity of genotypes and on heterozygosity within a cultivar contributes to higher and more stable yields (Link et al., 1994). Two hybrids (ICPH 2671 and ICPH 2740) were released by national partners working with ICRISAT for cultivation in India. Variety traits providing suitable floral resources and higher attractiveness for pollinating insects should be considered in breeding for the preservation of natural bee populations and also for their positive impact on pollination requirements and heterosis exploitation in agriculture (Palmer et al., 2009).

The common bean is a self-pollinated species but variability exists within landraces or heirloom varieties, that should be considered as a mixture of pure lines. It means that ecological and human factors accounted for the existence and stability of bean mixtures that could guarantee the flexibility of the varieties to be adapted to environmental variation. Kaplan (1981) showed that in comparison with single varieties, germination was delayed for the mixture of varieties, which means that in nature the period of emergence will be increased. It could be a security advantage since the timing of spring rain when common bean is sown is uncertain, so with different rates of germination the mean survival of a mixture could be improved. De Ron et al. (2004) demonstrated the coexistence of wild forms inside or quite close to some farms in the northwest of Argentina, sometimes in mixtures with cultivated forms maintained actively by farmers. The reasons for this situation are not clear but could be related to ancient customs and the diversity of uses of dry bean. This common bean germplasm could represent a real 
opportunity for breeding, considering that the Andean varieties currently cultivated in Europe display a narrow genetic basis.

Mixtures of cultivars have been proposed either in a field or at the level of a territory, in order to exploit favorable interactions between plant genotypes. These genotypic interactions often relate to complementarities of the cultivar components in resource acquisition and to reduced risk of damage from diseases or pests, over short or long periods of time (Finckha et al., 2000; Mundt, 2002; De Vallavieille-Pope, 2004; Mulumba et al., 2012).

\section{Towards Improved Positive Impacts of Legume Cultivars on Succeding Crops in Rotations}

Walley et al. (2007) reviewed a total of 230 published estimates of nitrogen fixation by different grain legumes including 79 estimates from pea and 38 from lentil, and calculated their contribution to soil $\mathrm{N}$ balance. They concluded that incremental changes in soil nitrogen due to planting grain legumes is highly associated with $\mathrm{N}$-fixation, but gave variable estimates of $\mathrm{N}$ derived from fixation depending on the type of pulse crop, microclimate, soil type and other crop production factors. Carrouée et al. (2012) and Jeuffroy et al. (2012) reported that wheat after pea yields 0.8 t.ha ${ }^{-1}$ more with a $\mathrm{N}$ input reduction of 20 to $30 \mathrm{~kg} \mathrm{~N} . \mathrm{ha}^{-1}$ and that a rapeseed after pea yields 0.1 to $0.2 \mathrm{t}^{\mathrm{h} \mathrm{ha}^{-1}}$ more with a $\mathrm{N}$ imput reduction of ca $40 \mathrm{~kg} \mathrm{~N} \cdot \mathrm{ha}^{-1}$. According to Walley et al. (2007), lentil crops needs to derive $47.8 \%$ of their $\mathrm{N}$ from fixation to leave a net positive $\mathrm{N}$ balance for the following crop. Analysis of the data suggested that faba bean, field pea and lentil do contribute positively to soil $\mathrm{N}$ economy over the long term, whereas chickpea and bean crops do not contribute at all, or contribute negatively. Thus, even if generally positive, it is not easy to make predictions on the $\mathrm{N}$ addition in soil from crop rotations including pulse crops on a short-term basis. The positive effect of a legume on the following crops in a rotation is also often explained by a reduction of diseases and parasites and to soil structure improvement. Differences between cultivars of the same species on the performance of the succeding crops can also be hypothesized, but never directly evaluated so far. Genotypes that display various patterns of root development, with quantitative or qualitative differences in their root exudates, that interact differently with soil microflora, with various efficiencies to remobilize $\mathrm{N}$ to seeds, and with a range of harvest indices, would be predicted to have different impacts on soil biology, structure and fertility, and consequently on the performance of the following crops.

\section{Breeding Grain Legumes for Better Adaption to Intercropping with a Non-Legume}

Intercropping legumes and cereals is a practical application of ecological principles of diversity, competition and facilitation which is still poorly represented in scientific literature (Figure 1) (Santalla et al., 1994; Hauggaard-Nielsen et al., 2007). In low nitrogen fertilizer environments, particularly organic farming, the combination of two species with complementary nitrogen acquisition pathways in space, time and requirements can improve the global performance of the plant population (Santalla et al., 2001b; Corre-Hellou et al., 2006; Naudin et al., 2010; Bedoussac and Justes, 2011). In these associations, the efficiency of resource use is improved and fossil energy consumption is reduced (Pelzer et al., 2012). Mechanisms of interspecific facilitations have been reported for iron or $\mathrm{P}$ uptake in intercropped systems (Zhang and Li, 2003).

Reductions of lodging, and pests or disease risks are frequently reported in these systems, but some cases of opposite observations were also reported (Boudreau, 2013). For instance, intercropping with cereals has been shown to be useful to reduce chocolate spot (Botrytis fabae) on faba bean (HauggaardNielsen et al., 2008; Fernández-Aparicio et al., 2010), ascochyta blight in pea (Jumel et al., 2010; Fernández-Aparicio et al., 2011) or broomrape (Orobanche crenata) in pea, lentil and faba bean (Fernández-Aparicio et al., 2007). Karel (1993) reported that incidence of pod borer insects Maruca testulalis (Geyer) and Heliothis armigera (Hubner) on common beans intercropped with maize was lower than in pure stands. The level of damages on an intercrop greatly varies according the pest or disease considered, to the plant species components and to the environment (Boudreau, 2013). In addition, the cultivar selection, in terms of whether it is a host or non-host for a given bioagressor must be considered in an intercropping strategy.

Santalla et al. (1994, 1995, 1999) evaluated the performance of the intercropping system common bean - maize, a usual practice in the NW of the Iberian Peninsula, as well as in many places of Central and South America. The absence of a bean population selected by cropping system interactions, suggested that breeding programs for intercropping may not be necessary or justifiable, as the best populations selected in sole cropping would also be suitable for intercropping under these conditions. Therefore, the final product of a selection program in a specific system under these environmental conditions will be well adapted to both systems. In wheat-pea intercropping, several trials conducted in France (Lecomte al., unpublished) revealed significant pea cultivar by wheat cultivar interactions, suggesting adapted ideotypes could be defined and proposed to breeders. Traits of optimal cultivars are still to be precisely defined, and they will be influenced by the choice of the partner species (cereal, rapeseed, etc.). Major traits will involve architecture and physiology of roots and shoots which will determine a complementation or competition for resources (light, water, minerals), standing ability of the plant population, synchronous earliness, adequate seed size to allow sorting seeds of the respective species, potential yields and finally uses to augment farmers income.

\section{E. Breeding Annual Grain Legumes for Intercropping with Each Other}

The published resources on the intercrops of two or more annual legume species are even less abundant. Some intercrops are beneficial, at least for one of the components, such as where white lupin may use more phosphorus than the accompanying 
soybean (Braum and Helmke, 1995); or where the intercropping of soybean and pigeon pea is combined with subsoiling and may reduce the effects of droughts of unpredictable intensity (Ghosh et al., 2006a). Annual legumes with known pharmaceutical properties and prominent biochemical potential such as fenugreek (Trigonella foenum-graecum L.), effectively reduce the infection of crenate broomrape in faba bean (Evidente et al., 2007; Fernández-Aparicio et al., 2011). However, in the intercrops of annual legumes, two components may compete for available nutrient resources resulting in the depression of growth of one of them, such as in the case of pigeon pea and soybean, where nitrogen was a limiting factor for growth of the former (Ghosh et al., 2006b). Also, the occurrence of the superiority of intercropping over pure stands may be limited, such as in the intercrop of two soybean cultivars, where only the highest plant density produces the expected result (Biabani et al., 2008).

During the past decade, the IFVC-University of Novi SadSerbia has carried out concerted research aimed at assessing the possibility of annual legume intercropping for forage production. Hundreds of accessions of numerous annual legume species of diverse origin and status in the collection maintained at IFVC were screened for their potential for intercropping with each other. Among the main conclusions of this preliminary testing are the following: species with long and lodging stems, such as vetches, easily control weeds in pure stands but suffer from forage yield losses; crops with good standing ability, such as faba bean, are regularly heavily infested by weeds in pure stands and require chemical control; intercropping annual legumes with inadequate growth habit gives significant advantage to one component, such as common vetch, and severely affects another, such as semi-leafless pea; a fully compatible intercropping, such as the one of white lupin and common vetch, provided the best outcomes (Ćupina et al., 2011).

The results led to four basic principles for optimizing intercropping of two annual forage legume species (Ćupina et al., 2011): (i) one has good standing ability (supporting crop), while another is susceptible to lodging (supported crop); (ii) same time of sowing; (iii) similar stem length; (iv) similar time of cutting. The recommended proportion of both components in an intercrop is $50 \%: 50 \%$, with the regular sowing rate of each component reduced by half in order to avoid expensive and economically unjustified sowing. Faba bean, white lupin, semileafless pea, fenugreek, soybean and pigeon pea play the role of supporting crop, while forage pea, various vetch species, grass pea, several Vigna species and lentil are used as the supported crop. So far, all the trials were aimed at improving green forage and forage dry matter yields and the land equivalent ratio (LER) higher than 1, where LER is calculated as (Kadžiulienè et al., 2010) $\mathrm{LER}=\mathrm{Y}_{\mathrm{A}}(\mathrm{IC}) / \mathrm{Y}_{\mathrm{A}}(\mathrm{SC})+\mathrm{Y}_{\mathrm{B}}(\mathrm{IC}) / \mathrm{Y}_{\mathrm{B}}(\mathrm{SC}),\left(\mathrm{Y}_{\mathrm{A}}(\mathrm{IC})\right.$ is the yield of the intercrop component $A$ in intercropping; $\mathrm{Y}_{\mathrm{A}}(\mathrm{SC})$ is the yield of the intercrop component $A$ in pure stand; $Y_{B}(I C)$ is the yield of the intercrop component $\mathrm{B}$ in intercropping; $\mathrm{Y}_{\mathrm{B}}(\mathrm{SC})$ is the yield of the intercrop component $\mathrm{B}$ in pure stand).
First results of the mutual intercrops of annual legumes for forage production generally confirm their reliability. Despite their preliminary nature, the obtained results offer a solid basis for defining the ideotypes for 'tall' cool season annual legumes and developing cultivars specifically for intercropping (Figure 10). Supporting crops may be characterized by more prominent basal branching and a slightly decreased proportion of lignin in stems. Supported crop genotypes should be selected for determinate stem growth and smaller number of stems per plant in order to avoid a potential negative impact on the development of the supporting crop (Mikić et al., 2012).

The assumption that crop diversity may have implications for positive roles in ecological and sustainable cropping systems has often been proposed but requires further study (Santalla et al., 2005; Smith et al., 2008). This evaluation of the impact of the species and cultivar variability requires long term and large space (farm, landscape) appraisal, often difficult to be handled by breeders alone. This objective needs large collaborations with other disciplines and with various stakeholders in the chain from producers to consumers.

\section{THE NEED TO DEVELOP THE USE OF GRAIN LEGUMES IN HUMAN FOODS AND TO COMBINE DEMANDS OF PRODUCTIVITY BY FARMERS TOGETHER WITH PROCESSOR AND CONSUMER EXPECTATIONS}

On a worldwide scale, food uses of grain legumes are dominant as they are used in many dishes depending on local culture and cuisine. In Europe which has massive deficit in protein rich feeds, grain legumes are primary used in animal husbandry. In this zone, pea and faba bean seeds are often introduced into feeds without fractioning or thermal treatments. This particular use has prompted breeding activities to increase protein content and to reduce the concentrations of antinutritional factors such as trypsin inhibitors and tannins from pea and faba bean, and vicine/convicine from faba bean (Crepon et al., 2011; Burstin et al., 2011). For human nutrition targets, some of these objectives remain valid such as the protein content increase to improve the nutritional value of the seed, or the vicine/convine reduction in faba bean to reduce the favism risk (Crepon et al., 2011). In the case of oilseed crops such as soybean, the demand for genetic improvement of seed composition has been weak because of the possibilities offered by processing.

Grain legumes are very abundant in human diets of developing countries, but incorporation in the human diets of all countries would be desirable, given their recognized nutritional value and health benefits (British Journal of Nutrition, review, 2012; Arnoldi et al., 2014; Vaz Patto et al., 2014). Their high protein content, and richness in some essential amino acids lacking in cereals, are an excellent complement to cereal-based foods. Contrary to cereals, most legume seeds are rich in lysine, but poor in sulfur containing amino acids. Various studies of mineral and vitamin content, starch components, fiber content, and 

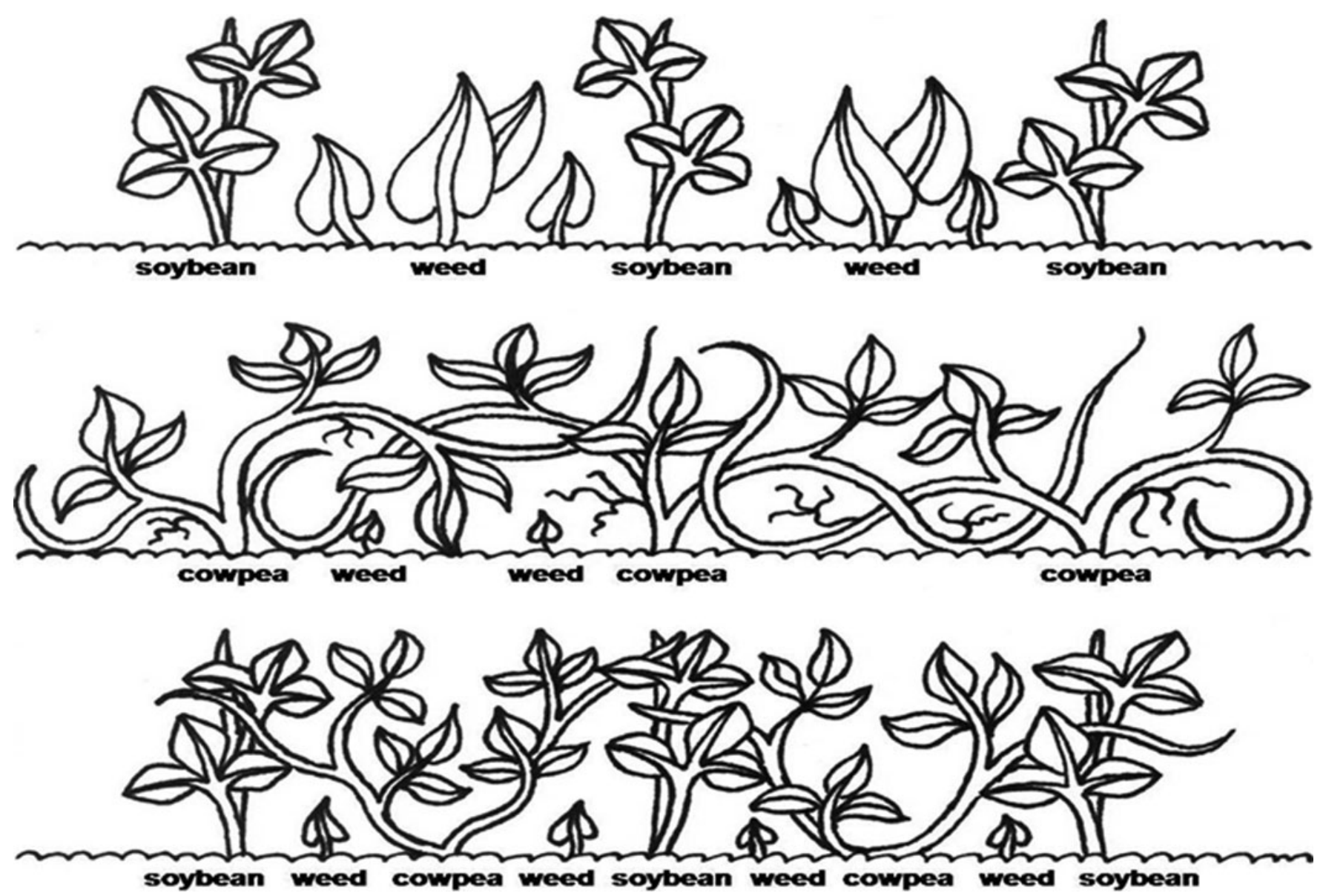

FIG. 10. Model of intercropping warm season legumes: (top row) soybean is lodging resistant but is in early danger from weeds; (middle row) cowpea almost completely eliminates weeds but has extreme lodging; (bottom row) intercropping soybean with cowpea is beneficial to both with efficient weed control (Mikić et al., 2012).

phytochemicals have elucidated the beneficial health effects of pea, chickpea and lentil (Faris et al., 2012; Jukanti et al., 2012; Thavarajah et al., 2007, 2010, 2013). Recent data also indicates that increased intake of grain legumes as reflected in higher intakes of fiber, protein, slowly digestible carbohydrate, folate, $\mathrm{Mg}, \mathrm{Fe}$ and $\mathrm{K}$ is leading to improved diet quality (Mudryj et al., 2012). Minor compounds, such as lipoxygenase or saponins, may be at the origin of unfavourable tastes therefore limiting use of some protein rich seed fractions as food ingredients, however various research studies are addressing this topic. Present national policies are orientated towards better balance between animal protein and crop protein production. In Europe, the need to reduce greenhouse gases and run-off of nutrients into groundwater also motivate consumers, public sector authorities and catering services to choose more balanced, environmentally friendly and diverse choices of food in their diet, which encourages an increase of grain legume uses (European Parlement, 2011).

The variability in seed composition of grain legumes has often both a genetic and environmental basis (Hood-Niefer et al., 2012). Traits of seed shape and colour have usually strong heritabilities and often characterize landraces co-adapted to tradi- tional uses. The genetic variability available in seed composition of diverse grain legumes is large for many seed components, and has been reviewed in Burstin et al. (2011). The review covers the major seed constituents (protein, carbohydrate, and fibers), and also minor components with potential bioactive activities such as trypsin inhibitors, lectins, alpha-galactosides, vicine and convicine, tannins, polyphenolics, flavonoids, and phytic acid.

\section{A. The Case of Common Bean}

Common bean is the most widely grown grain legume for direct human consumption and is highly preferred in many parts of Africa and Latin America (where it can be the most important source of dietary protein), as well as in traditional diets of the Middle East and the Mediterranean region (Broughton et al., 2003; Casquero et al., 2006). This legume is part of the healthy diet of the Mediterranean basin and is of growing importance in the USA where consumption has been increasing due to greater interest in "ethnic" and healthy foods (Blair and Izquierdo, 2012). Indeed it has lately gained attention as a functional food item due to its health benefits and disease prevention of non-communicable diseases as obesity, diabetes, 
cardiovascular diseases, and colon, prostate, and breast cancer (reviewed in Thompson, 2012).

Common bean breeding programs share a common goal to develop high yielding cultivars with desirable agronomic (abiotic stress and disease resistance) and quality traits (Santalla $e t$ al., 1995; Beaver and Osorno, 2009). However, legume breeders' efforts (common bean is no exception) have focused mainly on improving production and nutrition-related chemical composition (initially nutritional aspects such as protein content or amino acid content and later on, mineral and antinutritional factors content), while largely neglecting important sensory or processing traits (Plans et al., 2012). A holistic approach in breeding will be especially important when interactions are to be expected between some of the traits of interest to farmers, consumers and processors. This is the case for traits like seed size, mineral content, anti-nutritional compound content and yield. Also important will be the fact that breeding for particular constituents must take into account the balance of anti-nutritional and health promoting aspects of the compounds. Common bean breeders have increasingly used wild germplasm to enhance the genetic potential for seed yield (Santalla et al., 1995; Beaver and Osorno, 2009). However this can be especially challenging since wild bean species may contribute alleles for superior yield but inferior quality (Wright and Kelly, 2011). An attractive novel bean product is the "nuña" bean, a type of ancient common bean native to the Andean region of South America, whose seeds possess the unusual property of popping when roasted. The nutritional features of popped/roasted seeds make them a healthy low fat and high protein snack. Although the popping trait has been profusely studied in maize (popcorn), little is known about the biology and genetic basis of the popping/roasting ability in common bean (Yuste-Lisbona et al., 2012).

Understanding the molecular mechanisms underlying quality traits and their interaction with other traits is important for devising sustainable quality breeding approaches. Many quality traits are quantitative (Diaz et al., 2010) and somewhat influenced by the environment (Blair et al., 2009), but the molecular basis of the quality interactions has not been clarified yet. Several QTL studies for individual quality traits were performed in common bean, such as color retention after processing (Wright and Kelly, 2011), iron and zinc seed concentration (Blair et al., 2010, 2011), water absorption and coat proportion (Pérez-Vega et al., 2010), water absorption and cooking time (Vasconcelos Garcia et al., 2012), and more recently, seed phytate and phosphorus content (Blair et al., 2012) or nuña bean popping/roasting ability (YusteLisbona et al., 2012). In some cases candidate genes have been identified or at least associated molecular markers developed to use on QTL assisted selection.

These studies, however, have been limited in scope. None considered an integrated approach of multiple quality traits (with the exception that some considered seed weight or size), and some used bi-parental populations that could only be used to assess variation present between two parental accessions. Quality association mapping could overcome these limitations. An association approach has been successfully used for mapping bacterial blight resistance in common bean (Shi et al., 2011) and for some yield components (Galeano et al., 2012), but with a restricted number of SNP markers.

Molecular marker approaches have provided many tools to select for quantitative quality traits with difficult phenotypic evaluation. This was the case for symbiotic fixation capacity (Ramaekers et al., 2013), root pattern under drought stress (Asfaw and Blair, 2012), seed traits (González et al., 2009; 2010) or acquisition, accumulation and remobilization of photosynthates to the grain under drought (Asfaw et al., 2012), angular leaf spot resistance (Oblessuc et al., 2012) and candidate gene markers for common bean bacterial blight resistance (Shi et al., 2012). These will increase the options to pyramid/combine a range of tolerance mechanisms or quantitative resistances, with quality traits in cultivar development. With the recent development of high throughput genetic technologies, resulting for instance in the expansion of the already available common bean EST data (Kalavacharla et al., 2011; Blair et al., 2011a, 2011b), or the common bean intron based SNP markers (Galeano et al., 2012), with the subsequent development of a common bean Golden Gate SNP assay based on tentative orthologous genes (TOG) (Blair et al., 2013), or the development of a common bean DArT assay (Briñez et al., 2012), it is now possible to address bean quality breeding in a broader perspective. As the whole common bean genome sequence alignment will be soon available, it will be possible to identify and locate the associated candidate genes, thereby increasing the efficiency for transferring these quality aspects into new cultivars.

\section{B. The Case of Lentil and Pea}

A great variability in shapes, seed coat and cotyledon colours of dry seeds of pea and lentil have found multiple uses in foods (Muehlbauer et al., 2009; Slinkard and Vandenberg, 2000). Export markets are highly affected by quality parameters such as bleaching in peas and lentils and breeding for reduced bleaching has been successful. Ubayasena et al. $(2010 ; 2013)$ reported that the tissue affecting pea cotyledons in relation to bleaching was the seed coat. The gene expression profile study suggested that resistance to bleaching could be due to effective protection of seed coat membranes and chlorophyll pigments from photooxidation. Five genes were identified with direct effects on the bleaching resistance trait and future aims will be to characterize and validate the candidate genes for use in the development of gene specific markers.

Raffinose family oligosaccharides (RFOs) found in pulse crops have been associated with flatulence in humans, causing reluctance to increased consumption of these healthy foods. However, it is highly probable that grain legumes RFOs have prebiotic properties that may be of interest for protection against colorectal cancer (Champ, 2002). The biosynthetic pathway for these compounds is well known from work in other crops. Recently, completed studies into RFOs in lentil (Tahir et al., 2011) have demonstrated genetic variability in the level of RFOs in 
cultivated lentil and that the levels found in L. ervoides is only half the concentration found in cultivated lentil. It is important to evaluate the impact of a modification of the content in these factors on seed germination, the growth of the plant and its protection against stresses.

About $60-80 \%$ of the total phosphorous is stored in seeds in the form of phytate and this affects non-ruminant animals and humans. In spite of the rich content of minerals, bioavailability might be affected due to high phytate content in peas that inhibits the absorption of $\mathrm{Zn}, \mathrm{Fe}$ and $\mathrm{Ca}$. In an effort to develop lines with low phytate, pea mutants have been developed and characterized for low phytate concentration (Warkentin et al., 2012) which in turn improved the intake of essential elements.

Many nutritional studies are limited and involve only a few genotypes, thus clarification of the benefits of pulse crop diets in long-term studies with diversity of genotypes needs to be addressed. As is the case with major crops such as maize, results of nutritional studies on pulse crops have not yet been been fully integrated into the breeding programs as value added traits. QTLs for total proteins, protein fractions (legumins, vicilins, albumins), or particular albumins (trypsin inhibitors) were identified in pea (Bourgeois et al., 2009; Burstin et al., 2011) and markers were proposed to assist selection for an improved nutritional value. Association mapping studies are underway for zinc, iron and selenium concentration for common bean, chickpea, lentil and pea. QTL mapping for polyphenolic profiles in lentil is also in progress. Breeding materials that have gone through rigorous selection for other traits may also need to be evaluated for value added traits, or germplasm accessions with acceptable value added traits may need to be backcrossed to adapted lines. Introgressing value added traits from exotic materials (such as starch quality characteristics, protein composition, amino acid composition, carotenoid profile, mineral micronutrients and vitamins) for nutritional improvement of adapted pulse lines is also an alternative, as these are untapped resources.

Particular product quality objectives may impact negatively on crop yields. The breeding investments will require strong agreemment between stakeholders in the chain in order to build an added economic value of a given seed composition, and will also lead breeders to find trade-offs between yield and seed composition. For such multiple trait objectives, genomic strategies for breeding will be most appropriate. Information made available by genome sequencing, either achieved or underway (common bean, chickpea, pea, lentil, lupins), will provide useful tools for breeders with interests in improving nutritional profiles.

\section{USES OF ANNUAL GRAIN LEGUMES FOR FORAGE FOR A BETTER LINK WITH ANIMAL HUSBANDRY IN ARABLE LAND}

Intensification of modern agriculture and the use of imported feeds based on soybean meal tend to differentiate plant production territories on arable land from animal production areas.
It generates environmental costs for the transportation of raw materials and the use of slurry as fertilizers. The production of forages from annual grain legumes on arable lands may contribute to reducing the distances between plant and animal production. In addition, rising costs of inorganic fertilizers has renewed interest in legumes for cereal-based cropping systems.

Nearly all cool and warm season annual legume crops may be successfully used for forage production and as animal feed, especially for ruminants (Mihailović et al., 2005a). If soybean is presently grown almost exclusively as a protein and oil-seed crop in the USA, it was previously a popular summer annual forage legume. Soybean may still be considered as viable alternative forage when alfalfa or clover are in short supply, due to winter-killing or drought conditions. In temperate regions, the economically most important annual forage legumes are pea and vetches (Vicia spp.) while many neglected and underutilized grain legume crops, such as faba bean, lentil, grass pea, and white lupin may also be used for forage production. Grass pea has been identified as a good alternative to summer fallow if used as a ground cover, green manure or forage crop in several regions, as in the American Great Plains (Rao and Northup, 2008; Calderón et al., 2012). In warmer climates, soybean, pigeon pea, hyacinth bean (Lablab purpureus L.), and cowpea and other Vigna species are utilized for forage. Annual forage legumes may be used in feeding ruminants in numerous ways (Mikić et al., 2011a), such as fresh forage (Mikić et al., 2003), forage dry matter, forage meal, silage, haylage (Karagić et al., 2012), grazing (Mikić et al., 2006) and browsing.

In many temperate regions of the world, such as the USA, Western, Central and Eastern Europe and vast regions of Asia, forage annual legumes may be both autumn- and spring-sown (Mihailović et al., 2007a). Regardless of the growing season, forage annual legumes may be cultivated as sole crops, or in mixtures with cereals, which represents one of the most traditional ways of production in many regions of Europe, Western Asia and North Africa (Mihailović et al., 2011). The ratio of pea and the cereal component in a mixture is also part of the agricultural traditions specific for each country or region, varying between 75-80\% : 25-20\% in the Balkans (Mihailović et al., 2003 ) and 50\%:50\% in France or Lithuania (Sarunaite et al., 2013).

\section{A. Assessing the Potential of Forage Annual Legumes}

Every breeding programme on annual forage legumes requires thorough pre-breeding research on assessing the potential of each accession of a collection, with emphasis on a long-term evaluation of both forage yield, forage quality, and response to biotic and abiotic stresses (Mihailović et al., 2007b). Such an evaluation has been carried out in Novi Sad-Serbia for the last 12 years, with results that may be useful for other temperate regions in Europe and other parts of the world with similar agroecological environments. Results show that the annual legume crops with the highest forage dry matter yield in temperate 
regions are pea, faba bean, and hairy vetch among the cool season species, and soybean, cowpea, and pigeon pea among the warm season species. In many species, forage dry matter yield is negatively correlated with crude protein content in forage. This fact provides many annual legumes with an opportunity of being improved and transformed into forage crops, as the crude protein yield of the forage dry matter is at a similar level as the ones with much longer traditions of cultivation.

\section{B. Ideotypes in Breeding Forage Annual Legumes}

Both cultivated and wild annual legumes are characterized by a considerable variability of diverse morphological traits that are also important forage yield components, such as stem length, number of stems and lateral branches or number of leaves (Mikic et al., 2010a). This implies that the genetic resources of each annual legume represent a large gene pool of desirable agronomic traits that may be used in breeding programs aimed at developing cultivars for forage production. Although it is possible to define an ideotype for annual forage legume cultivars, each species has its own characteristics.

As one of the most economically important legume crops in the world after soybean (Ellis, 2007), pea has the widest range of variability for numerous morphological traits, which have been significantly accelerated by various breeding programmes (Ellis, 2009). Forage pea is one of the most distinctive agronomic types of the pea crop (Carrouée, 1993). The results of several long-term pre-breeding trials in Novi Sad-Serbia, including screening of hundreds of pea accessions of diverse status in terms of genetic resources and geographic origin, show that forage pea may be regarded as a crop with great potential for both forage dry matter and forage crude protein production. The fresh weight of pea forage is 45 to 50 t.ha $^{-1}$, the average forage dry matter yield ranges from 9 to 10 t.ha $^{-1}$ and an average forage protein yield varies between 1.5 to 2 t.ha $^{-1}$. Similar forage dry matter yields and crude protein contents have been obtained in spring forage pea cultivar trials in western Canada over the past five years (Mihailović et al., 2009a).

The main goal of forage pea breeding programs is a forage dry matter yield target of 10 tha $^{-1}$ with $20 \%$ variation of forage yields between years, combined with good winter hardiness, early maturity and high quality chemical composition (Mikić et al., 2011b). Forage yield can also be improved by selecting for moderately prominent basal branching (Mikić et al., 2013a). With increased branching, the most common ideotype of a forage pea cultivar is rather different from that of a grain pea cultivar (Figure 11, left). High quality in forage pea cultivars, in terms of desirable chemical composition, is directly and positively correlated with the proportion of leaves in the total forage yield, since leaves contribute most to forage protein yield. A classical forage pea cultivar has large stipules and two or three pairs of large leaflets. One of the alternative types of forage pea cultivars are those with an acacia leaf type (Figure 11, middle), characterized by a large number of leaflets and no tendrils. Although theoretically expected to have an increased leaf proportion and thus better forage quality, they are extremely prone to lodging, suffering either from low seed yield or large seed losses during harvest, and consequently their successful commercialisation is questionable (Mikić et al., 2011c). An additional targeted trait in all modern forage pea breeding programs is reliable seed yield. A forage pea cultivar, apart from high quality and stable forage yield, may be able to produce medium to high seed yield, enabling its successful commercialisation. Seed mass of less than $200 \mathrm{~g}$ per 1000 seeds increases the number of seeds per plant, increasing the coefficient of multiplication, and reduces sowing costs. Recent breeding efforts resulted in semi-leafless forage pea cultivars (Figure 11, right), with stem lengths up to $100 \mathrm{~cm}$, significantly improved standing ability, a greater number of internodes and large stipules. They provide high yield and high quality forage, with succulent thick stems making forage more palatable for ruminants. Pods are grouped in the upper half of the plant, increasing seed yield and decreasing seed losses during mechanical harvest (Warkentin et al., 2009).

Vetches (Vicia spp.) are one of the oldest annual legume crops used in animal feeding throughout the temperate regions of Europe, Near and Middle East and North Africa. The most important species are bitter vetch (V. ervilia (L.) Willd.), Hungarian vetch (V. pannonica Crantz), common vetch (V. sativa L.) and hairy vetch (V. villosa Roth) (Mihailović et al., 2005b). Generally, breeding programs for bitter vetch, common vetch and Hungarian vetch are more advanced in the countries of southern Europe, Asia Minor and Near East (Mihailović et al., 2009b), while hairy vetch is receiving more interest as green manure in North America and Japan. The main goal of all forage vetch breeding programs is high and stable forage yield with high quality chemical composition, aiming for green forage yield of more than $45{\mathrm{t} . h a^{-1}}$ in winter and more than $40 \mathrm{t}^{-h a^{-1}}$ in spring cultivars, forage dry matter yield of about $8.5 \mathrm{tha}^{-1}$, variation of forage yields between years less than $20 \%$ and improved winter hardiness and early maturity (Mikić et al., 2013b). If cultivated for forage, an ideotype of a vetch plant should be characterized by slender stems with determinate growth, a total of 15 photosynthetically active leaves at the full flowering stage, and large leaflets. Determinate growth is one of the essential traits, since it prevents excessive lodging and the economically significant loss of lower leaves that easily degrade after lodging. However, an ortholog of the pea gene $D E T$, controlling determinate growth of the main stem, has not yet been discovered. Closely related is the goal of uniform maturity, in terms of both concurrent flowering and pod and seed development. Wild type vetches, especially in hairy vetch, are notorious for indeterminate stem growth and extremely prolonged flowering and seed maturity. Flowers, young pods and shattered seeds may occur at the same time in one plant (Mihailović et al., 2008). A separate aspect relevant to all annual forage legume breeding is combining all desirable traits related to forage yield with high and reliable seed yield, which is necessary for commercial success. Several wild 


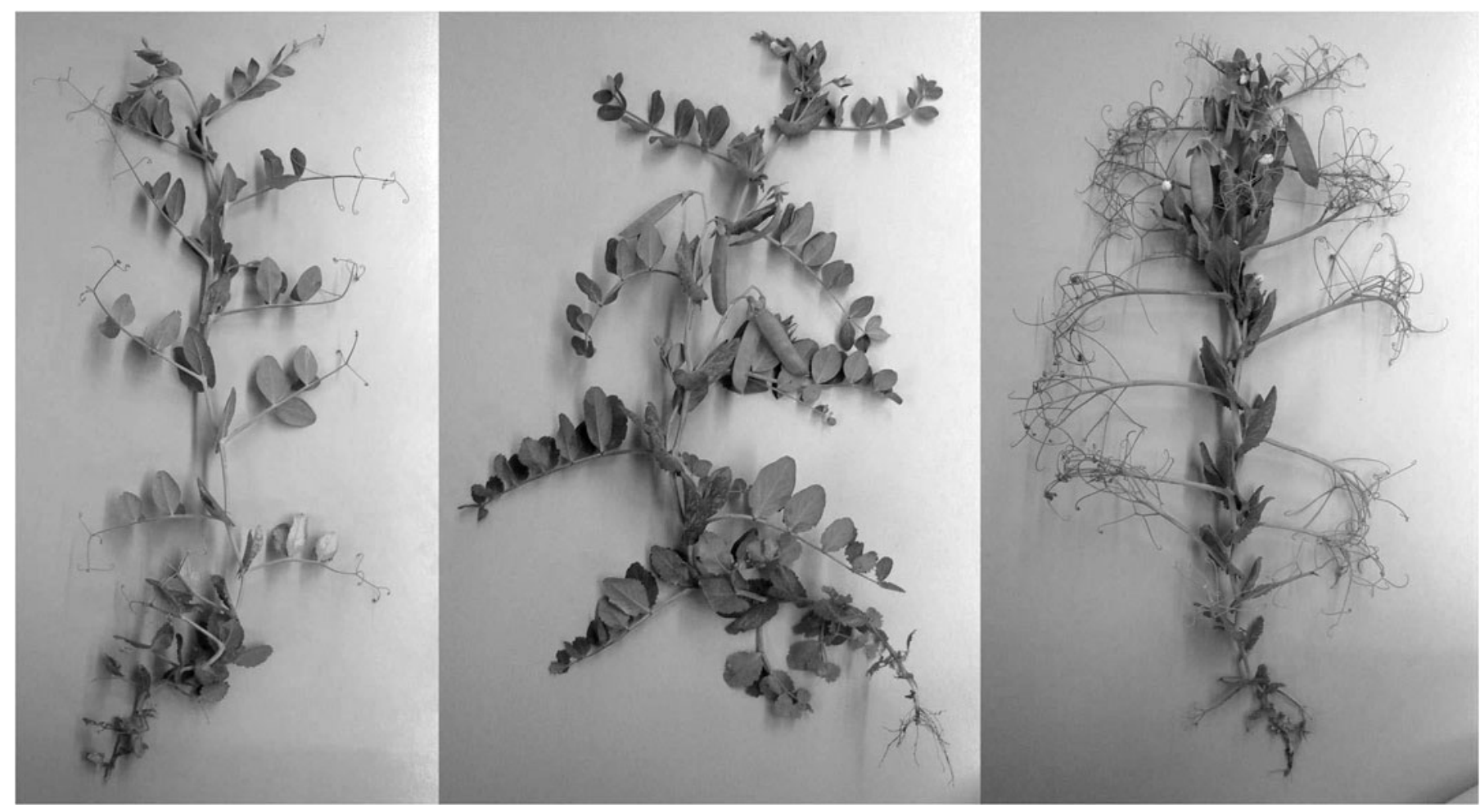

FIG. 11. Various ideotypes of a forage pea cultivar: classical (left), in comparison to typical grain pea cultivars; acacia-leafed (middle); semi-leafless (right) (Mihailović et al., 2009).

vetch species have been assessed for potential for reliable forage production, such as narrow-leafed ( $V$. sativa subsp. sativa) and large-flowered vetches (V. grandiflora Scop.) (Mikić et al., 2008, 2009a, 2013a).

Breeding other annual legumes for forage is not as advanced, despite promising preliminary results (Mihailović and Mikić, 2010). It may be concluded that for all annual legume species with good standing ability, such as faba bean, white lupin, soybean and pigeon pea, an ideotype of the cultivar for forage production should be characterized by less mechanical tissue in stems and thus have a better digestibility (Mikić et al., 2007; Mihailović et al., 2012). On the other hand, in the species with poor lodging tolerance, such as grass pea, Narbonne vetch ( $V$. narbonensis L.) or cowpea, the primarily targeted traits comprise determinate stem growth and a length up to $100 \mathrm{~cm}$ without decreasing the number of nodes, in order to preserve as many active leaves as possible until the stage of full flowering (Mikić et al., 2009b; Mihailović et al., 2013). An additional essential trait in breeding warm season forage annual legumes for temperate regions is developing genotypes with day neutral photoperiod, providing both high forage yield and reliable seed yield for commercialisation. This is particularly important for the warm season species like pigeon pea (Mihailović et al., 2006) and cowpea (Mikić et al., 2009c).

\section{USES OF ANNUAL LEGUMES AS GREEN MANURE}

Apart from various food and feed uses, annual legumes may represent a quality green manure, playing one of the most significant roles in organic farming and sustainable agriculture (Ćupina et al., 2004a). In addition to their ability to increase soil fertility by symbiosis with nitrogen-fixation bacteria, annual legumes are able to produce a considerable amount of aboveground biomass, also rich in nitrogen, which may help to reduce chemical fertilizers when used as green manure (Ćupina et al., 2004b). A long-term evaluation of the potential of annual legumes for green manure production demonstrated a considerable potential in the majority of economically important annual legumes, with aboveground biomass $\mathrm{N}$ yield of more than $250 \mathrm{~kg} \cdot \mathrm{ha}^{-1}$ for faba bean (Mihailović and Mikić, 2010), nearly $350 \mathrm{~kg} \cdot \mathrm{ha}^{-1}$ for white lupin (Mikić et al., 2010b) and grass pea (Mikić et al., 2011a) and greater than $100 \mathrm{~kg} \cdot \mathrm{ha}^{-1}$ for lentil (Antanasović et al., 2013). If cut in full bloom (in temperate regions in May) and incorporated, the aboveground biomass of most annual legumes have long-term and beneficial effects on the productivity of numerous succeeding crops, such as silage maize (Zea mays L.) or sorghum (Sorghum bicolour (L.) Moench). Maize and sorghum have shown significant increases in both green forage and forage dry matter yield and quality after green manuring with legumes (Ćupina et al., 2011a). 
Recently, specific breeding programs have been launched on annual legumes for their non-food use as green manure, aimed at developing cultivars with large amounts of high quality aboveground biomass. An additional objective is rapid degradation when incorporated, due to a decreased proportion of lignin and cellulose. The novel cultivars of annual legumes for green manure should ideally develop a larger amount of underground biomass in comparison to cultivars for forage or grain production, with balanced deposition of nitrogen between root and aboveground plant parts (Bourion et al., 2007). This requires changes in the annual legume root architecture and morphology, which remains one of the most difficult tasks for annual legume breeders who traditionally deal mostly with improving aboveground canopy characteristics.

Cultivars bred for grain production are frequently the first genotypes tested in forage or green manure production because of their availability. However, targets are basically different with demands (i) of large biomass but a lower concern about harvest index performance, (ii) of small seeds to reduce sowing costs, (iii) of various phenologies adapted to different cropping systems, and (iv) of shoot composition requirements instead of seed composition. These original demands encourage a new evaluation of genetic resources for these uses. Such developments in favour of more diverse cropping systems involving larger area of legumes must be accompanied by a thorough evaluation of all associated biotic stress risks.

\section{CONCLUSIONS}

Legumes provide a major ecosystem service by acquiring their nitrogen from the air through symbiosis with Rhizobium spp. It results in substantial $\mathrm{N}$ fertilizer savings, and this agroecological function provided by legumes is positive as long as stored $\mathrm{N}$ is well managed in the cropping system, with minimal $\mathrm{N}$ leaching or $\mathrm{N}_{2} \mathrm{O}$ formation after crop harvest. Legume products have high nutritional and health value for foods or feeds, and breeding can amplify these qualities. This paper describes the diverse potential ecosystem services provided by legumes in cropping systems. As a whole, such objectives and their underlying mechanisms require that breeding progams employ a holistic approach with multi-trait aspects and multi-scale dimensions in time and space through the entire stakeholders value chain (farmers, processors and consumers).

The large genetic diversity available in legume germplasm collections should be used to focus breeding towards genotypes adapted to innovative cropping systems. This will require more research to identify the key traits involved in the ecosystem services, and will require modeling. The model-assisted design of new ideotypes should predict yield and other services on the basis of environment parameters (climate, soil, inputs and practices), using rules of plant functions such as plant responses through genetic parameters and genetic correlations.

The objectives of new ecosystem services is leading breeders to evaluate a range of new traits such as (i) the adaptation to new cropping systems, (ii) the competition/facilitation ability between individuals in sole crop or intercrop systems, and (iii) the interaction with accompanying organisms (including soil microflora, pollinating or parasitic insects, and weeds). The ultimate goals of breeders searching for cultivars that yield reliably in the context of climate change and also to provide agroecological functions, will be to integrate several dimensions such as (i) environmental friendly functions, (ii) efficiency in capturing resources, (iii) reduction or exploitation of crop residues, and (iv) providing new food, feed or non-food uses.

In breeding, the most common methods will remain valid (pedigree, bulk, backcross and various modification of the bulk method, including single seed descent and mass pedigree transgenesis). Targeted traits will orient the phenotyping towards new traits identified in the modeling analysis and in the definition of ideotypes. It will require the exploration of wider genetic germplasm (wild forms, interspecific crosses, mutant populations, etc.) and this larger view will be helped by the combination of high throughput phenotyping with high throughput genomics, in order to build more rapidly and precisely the combinations of genes required in the multitraits targets. The cost of genome sequencing and bioinformatics is dropping steadily and genomic resources are increasing in most important annual legumes. Some organizations with advanced infrastructure are now engaging in sequencing efforts for minor crops (full genome sequence already available in soybean, chickpea and soon available for common bean, pea, lentil, and narrow-leafed lupin). This new context is favorable to the development of association genetics, and breeding may be assisted in the near future by genomics-assisted breeding. Genome wide selection holds considerable promise to (Nakaya and Isobe, 2012) help more efficiently perform multi-trait selection, to determine trade-offs and to manipulate genetic correlations between traits. Finally, genetic diversity may be increased with the possibility of mixing species and cultivars over a landscape, a farm or a field.

\section{FUNDING}

This research was partly supported by the following projects: (1) FP7 LEGATO, European Union; (2) Project UWA00147 from the Grains Research and Development Corporation-Australia; (3) ECONET- PAVLE SAVIC projects, Ministry of Foreign Affairs-France and PARI-1 Agrale 62010-2013, Burgundy Council-France; (4) Fundação para a Ciência e a Tecnologia-Portugal through grants \#PEstOE/EQB/LA0004/2013 and \#PTDC/AGR-TEC/3555/2012 and Research Contracts by the Ciência 2008 program to MCVPPortugal; (5) TR-31024 of the Ministry of Education, Science and Technological Development- Republic of Serbia; (6) PET2008-0167-01 and AGL2011-25562 of the Government of Spain and INCITE07PXI403088ES of the Government of Galicia-Spain. 


\section{REFERENCES}

Abate, T., Alene, A. D., Bergvinson, D., Shiferaw, B., Silim, S., Orr, A., and Asfaw, S. 2012. Tropical GrainLegumes in Africa and South Asia: Knowledge and Opportunities. Research Report No. 1. International Crops Research Institute for the Semi-Arid Tropics, Nairobi, Kenya. ISBN 978-92-9066544-1.

Abd El-Moneim, A. M. and Cocks, P. S. 1993. Adaptation and yield stability of selected lines of Lathyrus spp. under rainfed conditions in West Asia. Euphytica 66: 89-97.

Abd El Moneim, A. M., van Dorrestein, B., Baum, M., Ryan, J., and Vejiga, G. 2001. Role of ICARDA in improving the nutritional quality and yield potential of grasspea (Lathyrus sativus L.), for subsistence farmers in dry areas. Lathyrus Lathyrism Newsl. 2: 55-58.

Allkin, R., Goyder, D. J., Bisby, F. A., and White, R. J. 1986. Names and synonyms of species and subspecies in the Vicieae. Issue 3. Vicieae Database Project. Southampton University.

Almeida, N. F., Leitão, S. T., Caminero, C., Torres, A. M., Rubiales, D., and Vaz Patto, M. C. 2014. Transferability of molecular markers from major legumes to Lathyrus spp. for their application in mapping and diversity studies. Mol. Biol. Rep. 41: 269-283.

Andrivon, D., Giorgetti, C., Baranger, A., Calonnec, A., Cartolaro, P., Faivre, R., Guyader, S., Lauri, P. E., Lescouret, F., Parisi, L., Ney, B., Tivoli, B., and Sache, I. 2013. Defining and designing plant architectural ideotypes to control epidemics? Eur. J. Plant Pathol. 135: 611-617.

Antanasović, S., Ćupina, B., Krstić, Đ., Mikić, A., Mihailović, V., Manojlović, M., and Čabilovski, R. 2013. Potential of lentil (Lens culinaris) as a green manure crop. J. Lentil Res. 5: 40-43.

Araújo, S. S., Beebe, S., Crespi, M., Delbreil, B., González, E. M., Gruber, V., Lejeune-Henaut, I., Link, W., Monteros, M. J., Prats, E., Rao, I., Vadez, V., and Vaz Patto, M. C. 2014. Abiotic stress responses in legumes: Strategies used to cope with environmental challenges. Crit. Rev. Pl. Sci. this issue.

Arnoldi, A., Zanoni, Ch., Lammi, C., and Boschin, G. 2014. The role of grain legumes in the prevention of hypercholesterolemia and hypertension. Crit. Rev. Pl. Sci. this issue.

Asfaw, A., Blair, M. W., and Struik, P. C. 2012. Multienvironment Quantitative Trait Loci analysis for photosynthate acquisition, accumulation, and remobilization traits in common bean under drought stress. G3 2: 579-595.

Auger, R.M. 2001. Water relations, drought and vesicular-arbuscular mycorrhizal symbiosis Mycorrhiza 11: 3-42.

Banniza, S., Hashemi, P., Warkentin, T. D., Vandenberg, A., and Davis, A. 2005. The relationship among lodging, stem anatomy, degree of lignification and susceptibility to Mycosphaerella blight in field pea (Pisum sativum L.). Can. J. Bot. 83: 954-967.

Beaver, J. S., and Osorno J. M. 2009. Achievements and limitations of contemporary common bean breeding using conventional and molecular approaches. Euphytica 168: 145-176.

Bedousac, L., and Justes, E. 2011. The efficiency of a durum wheat-winter pea intercrop to improve yield and wheat grain protein concentration depends on $\mathrm{N}$ availability during early growth. Plant Soil 330: 19-35.

Berger, J. D., Buirchell, B., Luckett, D. J., and Nelson, M. N. 2012a. Domestication bottlenecks limit genetic diversity and constrain adaptation in narrow-leafed lupin (Lupinus angustifolius L.). Theor. Appl. Genet. 124: 637652.

Berger, J. D., Buirchell, B., Luckett, D. J., Palta, J. A., Ludwig, C., and Liu, D. 2012b. How has narrow-leafed lupin changed in its 1 st 40 years as an industrial, broad-acre crop? A GxE-based characterization of yield-related traits in Australian cultivars. Field Crop. Res. 126: 152-164.

Berger, J. D., Clements, J. C., Nelson, M. N., Kamphuis, L. G., Singh, K. B., and Buirchell, B. 2013. The essential role of genetic resources in narrow-leafed lupin improvement. Crop Pasture Sci. 64: 361-373.

Berger, J. D., and Ludwig, C. 2014. Contrasting adaptive strategies to terminal drought stress gradients in Mediterranean legumes: phenology, productivity and water relations in wild and domesticated Lupinus luteus L. J. Exp. Bot. (accepted).
Berger, J. D., Milroy, S. P., Turner, N. C., Siddique, K. H. M., Imtiaz, M., and Malhotra, R. 2011. Chickpea evolution has selected for contrasting phenological mechanisms among different habitats. Euphytica 180: 1-15.

Biabani, A., Hashemib, M., and Herbert, S. J. 2008. Agronomic performance of two intercropped soybean cultivars. Int. J. Plant Prod. 2: 215-222.

Blair, M. W., Astudillo, C., Rengifo, J., Beebe, S. E., and Graham, R. 2011a. QTL analyses for seed iron and zinc concentrations in an intra-genepool population of Andean common beans (Phaseolus vulgaris L). Theor. Appl. Genet. 122: 511-521.

Blair, M. W., Chaves, A., Tofiño, A, Calderón, J. F., and Palacio, J. D. 2010. Extensive diversity and inter-gene pool introgression in a world-wide collection of indeterminate snap bean accessions. Theor. Appl. Genet. 120: 1381-1391.

Blair, M. W., Cortés, A. J., Penmetsa, R. V., Farmer A., Carrasquilla-Garcia, N., and Cook, D. R. 2013. A high-throughput SNP marker system for parental polymorphism screening, and diversity analysis in common bean (Phaseolus vulgaris L.). Theor. Appl. Genet. 126: 535-548.

Blair, M. W., Herrera, A. L., Sandoval, T. A., Caldas, G. V., Filleppi, M., and Saprvol, I. F. 2012. Inheritance of seed phytate and phosphorus levels in common bean (Phaseolus vulgaris L.) and association with newly-mapped candidate genes. Mol. Breeding 30: 1265-1277.

Blair, M. W., Hurtado, N., Chavarro, C. M., Munoz-Torres, M. C., Giraldo, M. C., Pedraza, F., Tomkins, J., and Wing, R. 2011b. Gene-based SSR markers for common bean (Phaseolus vulgaris L.) derived from root and leaf tissue ESTs: An integration of the BMc series. BMC Plant Biol. 11: 50-59.

Blair, M. W., and Izquierdo, P. 2012. Use of the advanced backcross-QTL method to transfer seed mineral accumulation nutrition traits from wild to Andean cultivated common beans. Theor. Appl. Genet. 125: 1015-1031.

Blair, M. W., Muñoz-Torres, M., Giraldo, M. C., and Pedraza, F. 2009. Development and diversity assessment of Andean-derived, gene-based microsatellites for common bean (Phaseolus vulgaris L.). BMC Plant Biol. 9: 100.

Blair, M. W., Soler, A., and Cortés, A. J. 2012. Diversification and population structure in common beans (Phaseolus vulgaris L.). PLoS ONE 7: e49488.

Bourgeois, M., Jacquin, F., Savois, V., Sommerer, N., Labas, V., Henry, C., and Burstin, J. 2009. Dissecting the proteome of pea mature seeds reveals the phenotypic plasticity of seed protein composition. Proteomics 9: 254271.

Boudreau, M.A. 2013. Diseases in intercropping systems. Аnпu. Rev. Phytopathol. 51: 499-519.

Bourion, V., Laguerre, G., Depret, G., Voisin, A. S., Salon, C., and Duc, G. 2007. Genetic variability in nodulation and root growth affects nitrogen fixation and accumulation in pea. Ann. Bot.-London 100: 589-598.

Bourion, V., Martin, C., de Larambergue, H., Jacquin, F., Aubert, G., MartinMagniette, M-L., Balzergue, S., Lepetit, M., Munier-Jolain, N., Salon, C., and Duc, G. 2014. Unexpected low nitrogen acquisition and absence of root architecture adaptation to nitrate supply in a Medicago truncatula highlybranched root mutant. J. Exp. Bot. (accepted for publication).

Bourion, V., Rizvi, S. M. H., Fournier, S., De Larambergue, H., Galmiche, F., Marget, P., Duc, G., and Burstin, J. 2010. Genetic dissection of nitrogen nutrition in pea through a QTL approach of root, nodule, and shoot variability. Theor. Appl. Genet. 121: 71-86.

Braum, S. M., and Helmke, P. A. 1995. White lupin utilizes soil phosphorus that is unavailable to soybean. Plant Soil 176: 95-100.

Brinez, B., Blair, M., Kilian, A., Carbonell, S., Chiorato, A., and Rubiano, L. 2012. A whole genome DArT assay to assess germplasm collection diversity in common beans. Mol. Breeding 30: 181-193.

British Journal of Nutrition. 2012. The nutritional value and health benefits of pulses for obesity, diabetes, heart disease and cancer. Brit. J. Nut. 108, supp 1 .

Broughton, W. J., Hernandez, G., Blair, M., Beebe, S., Gepts, P., and Vanderleyden, J. 2003. Beans (Phaseolus spp.) - model food legumes. Plant Soil 252: 55-128.

Brücher, B., and Brücher, H. 1976. The south American wild bean (Phaseolus aborigeneus Burk.) as an ancestor of the common bean. Econ. Bot. 30: 257-272. 
Brunet, J., Repellin, A., Varrault, G., Terryn, N., and Zuily-Fodil, Y. 2008 Lead accumulation in the roots of grass pea (Lathyrus sativus $\mathrm{L}$.): a novel plant for phytoremediation systems? C. R. Biol. 331: 859-864.

Burstin, J., Gallardo, K., MIirr, R., Varshney, R. R., and Duc, G. 2011. In: Improving Protein Content and Nutrition Quality in Biology and Breeding of Food Legumes, pp. 314-328. Pratap, A. and Kumar, J., Eds., Cabi Publishing. ISBN 9781845937669.

Burstin, J., Marget, P., Huart, M., Moessner, A., Mangn, B., Duchene, C., Desprez, B., Munier-Jolain, N., and Duc, G. 2007. Developmental genes have pleiotropic effects on plant morphology and source capacity, eventually impacting on seed protein content and productivity in pea. Plant Physiol. 144: 768-781.

Calderón, F. J., Vigil, M. F., Nielsen, D. C., Benjamin, J. G., and Poss, D. J. 2012. Water use and yields of no-till managed dryland grasspea and yellow pea under different planting configurations. Field Crop. Res. 125:179185.

Campa, A., Giraldez, R., and Ferreira, J. J. 2011. Genetic analysis of the resistance to eight Anthracnose races in the common bean differential cultivar Kaboon. Phytopathology 101: 757-764.

Campbell, C. G. 1997. Grass Pea. Lathyrus sativus L. Promoting the Conservation and Use of Under-Utilized and Neglected Crops. 18. Institute of Plant Genetics and Crop Plant Research. Gatersleben/International Plant Genetic Resources Institute, Rome, Italy.

Campbell, C. G., Mehra, R. B., Agrawal, S. K., Chen, Y. Z., El Ali, A. M. A, Khawaja, H. I. T., Yadav, C. R., Toy, J., and Araya, W. A. 1994. Current status and future strategy in breeding grass pea (Lathyrus sativus). Euphytica 73: $167-175$.

Carrouée, B. 1993. Different types of peas: to clarify a complex status. Grain Legumes. 3: 26-27.

Carrouée, B., Schneider, A., Flénet, F., Jeuffroy, M. H., and Nemecek, T. 2012. Introduction du pois protéagineux dans des rotations à base de céréales à paille et colza : impacts sur les performances économiques et environnementales. Innovations Agronomiques 25: 125-142.

Casquero, P. A., Lema, M., Santalla, M., and De Ron, A. M. 2006. Performance of common bean landraces from Spain in the Atlantic and Mediterranean environments. Genet. Resour. Crop Ev. 53: 1021-1032.

Chadirasekaran, R., Warkentin, T. D., Gan, Y., Shirtliffe, S., Gossen, B. D., Tar'an, B., and Banniza, S. 2009. Improved sources of resistance to ascochyta blight in chickpea. Can. J. Plant Sci. 89: 107-118.

Champ, M. 2002. Non-nutrient bioactive substances of pulses. Brit. J. Nut. Suppl 3: S307-S319.

Cheng, X., Wang, S., Wu, S., Zhou J., Wang, S., and Yang, C.Y. 2005. Tagging and utilization of bruchid resistance gene using PCR markers in mungbean. Scientia Agricultura Sinica 38: 1534-1539.

Clement, S. L., Wightman, J. A., Hardie, D. C., Bailey, P., Baker, G., and McDonald, G. 2000. Opportunities for integrated management of insect pests of grain legumes. In: Linking Research and Marketing Opportunities for Pulses in the 21 st Century. pp. 467-480. Knight, R. Ed., Kluwer Academic, Dordrecht, The Netherlands.

Corre-Hellou, G., Fustec, J., and Crozat, Y. 2006. Interspecific competition for Soil $\mathrm{N}$ and its interaction with $\mathrm{N} 2$ fixation, leaf expansion and crop growth in pea-barley intercrops. Plant Soil 282: 195-208.

Courty, P. H., Smith, P., Koegel, S., Redecker, D., and Wipf, D. 2014. Inorganic Nitrogen uptake and transport in beneficial plant root-microbe interactions. Crit. Rev. Pl. Sci. this issue.

Crepon, K., Marget, P., Peyronnet, C., Carrouée, B., Arese P., and Duc, G. 2010. Nutritional value of faba bean (Vicia faba L.) seeds for feed and food. Field Crop. Res. 115: 329-339.

Ćupina, B., Erić, P., Krstić, D., and Vučković, S. 2004a. Forage catch crops in sustainable agriculture and organic farming. Acta Agric. Serb. IX, special issue: $451-459$.

Ćupina, B., Erić, P., Mihailović, V., and Mikić, A. 2004b. The role and importance of cover crops in sustainable agriculture. Ratar. Povrt. 40: 419430.
Ćupina, B., Manojlović, M., Krstić, Đ., Čabilovski, R., Mikić, A., IgnjatovićĆupina, A., and Erić, P. 2011a. Effect of winter cover crops on the dynamics of soil mineral nitrogen and yield and quality of Sudan grass (Sorghum bicolor (L.) Moench). Aust. J. Crop Sci. 5: 839-845.

Ćupina, B., Mikić, A., Stoddard, F. L., Krstić, Đ., Justes, E., Bedoussac, L., Fustec, J., and Pejić, B. 2011b. Mutual legume intercropping for forage production in temperate regions. In: Sustainable Agriculture Reviews 7: Genetics, Biofuels and Local Farming Systems. pp. 347-365. Lichtfouse, E., Ed., Springer Science+Business Media, Dordrecht.

Dar, W. D., Reddy, B. V. S., Gowda, C. L. L., and Ramesh, S. 2006. Genetic resources enhancement of ICRISAT mandate crops. Curr. Sci. India 91: 880-884.

De Ron, A. M., Menéndez-Sevillano, and M. C., Santalla, M. 2004. Variation in primitive landraces of common bean (Phaseolus vulgaris L.) from Argentina. Genet. Resour. Crop Evol. 51: 883-894.

Debouck, D. G., and Smartt, J. 1995. Bean. In: Evolution of Crop Plants, 2nd $e d$, pp. 287-296. Smartt, J. and Simmonds, N. W., Eds., Longman Scientific and Technical, England.

Depret, G., and Laguerre, G. 2008. Plant phenology and genetic variability in root and nodule development strongly influence genetic structuring of Rhizobium leguminosarum biovar viciae populations nodulating pea. New Phytol. 179: 224-235.

De Vallavieille-Pope, C. 2004. Management of disease resistance diversity of cultivars of a species in single fields: controlling epidemics. C. R. Biol. 327: 611-620.

Denison, R.F. 2000. Legume sanctions and the evolution of symbiotic cooperation by rhizobia. The American Naturalist 156: 567-576.

Devine, T. E., and Breithaupt, B. H. 1980. Significance of incompatibility reactions of Rhizobium japonicum strains with soyabean host genotype. Crop Sci. 80: 269-271.

Díaz, A. M., Caldas, G. V., and Blair, M. W. 2010. Concentrations of condensed tannins and anthocyanins in common bean seed coats. Food Res. Int. 43: 595-601.

Duc, G., Mariotti, A., and Amarger, N. 1987. Measurements of genetic variability for symbiotic dinitrogen fixation in field grown faba bean (Vicia faba L.) using a low level $15 \mathrm{~N}$ tracer technique. Plant Soil 106: 269276.

Duc, G, Trouvelot, A, Gianinazzi-Pearson, V, and Gianinazzi, S. 1989. A first report of non mycorrhizal plant mutants (Myc-) obtained in pea. Plant Sci. 60: $215-222$.

Ellis, T. H. N. 2007. Approaches to the isolation of genes of agronomic importance in pea. Ratar. Povrt. 44: 45-47.

Ellis, T. H. N. 2009. Legume genetics and breeding: the example of pea. Grain Legumes 51: 14-15.

Ellis, T. H. N. 2011. Pisum. In: Wild Crop Relatives: Genomic and Breeding Resources (Legume Crops and Forages), pp. 237-248. Kole, C., Ed., Springer, New York.

Escribano, M. R., De Ron, A. M., and Amurrio, J. M. 1994. Diversity in agronomical traits in common bean populations from Northwestern Spain. Euphytica 76: 1-6.

Etévé, G. 1985. Breeding for Tolerance and Winter Hardiness in Pea. In: The Pea Crop a Basis for Improvement, pp 163-172. Hebblethwaite, P. D., Heath, M. C., and Dawkins, T.C.K., Eds., Butterworths, London.

European Parlement 2011, (http://www.europarl.europa.eu/sides/getDoc.do? type $=$ REPORT\&reference $=$ A7-2011-0026\&language $=E N$ ), accessed November 15, 2013.

Evidente, A., Fernández-Aparicio, M., Andolfi, A., Rubiales, D., and Motta, A. 2007. Trigoxazonane, a monosubstituted trioxazonane from Trigonella foenum-graecum root exudate, inhibits Orobanche crenata seed germination. Phytochemistry 68: 2487-2492.

FAO Statistics Division. 2011-2012. FAOSTAT, (http://faostat.fao.org/), accessed November 15, 2013.

Faris, M. A., Takruri, H. R., and Issa, A. Y. 2013. Role of lentils in human health and nutrition: a review. Mediterr. J. Nutr. Metab. 6: 3-16. 
Fernández-Aparicio, M., Amri, M., Kharrat, M., and Rubiales, D. 2010. Intercropping reduces Mycosphaerella pinodes severity and delays upward progress on the pea plant. Crop Prot. 29: 744-750.

Fernández-Aparicio, M., Emeran, A. A., and Rubiales D. 2011. Inter-cropping faba bean with berseem, fenugreek or oat can contribute to broomrape management. Grain Legumes 56: 31.

Fernández-Aparicio, M., Flores, F., and Rubiales, D. 2009a. Recognition of root exudates by seeds of broomrape (Orobanche and Phelipanche) species. Ann. Bot.-London 103: 423-431.

Fernández-Aparicio, M., Flores, F., and Rubiales, D. 2012. Escape and true resistance to crenate broomrape (Orobanche crenata Forsk.) in grass pea (Lathyrus sativus L.) germplasm. Field Crop. Res. 125: 92-97.

Fernández-Aparicio M., Shtaya M., Emeran A. A., Allagui M. B., Kharrat M., and Rubiales D. 2011. Effects of crop mixtures on chocolate spot development on faba bean grown in mediterranean climates. Crop Prot. 30: 1015-1023.

Fernández-Aparicio, M., Sillero, J. C., and Rubiales, D. 2007. Intercropping with cereals reduces infection by Orobanche crenata in legumes. Crop Prot. 26: $1166-1172$.

Fernández-Aparicio, M., Sillero, J. C., and Rubiales, D. 2009b. Resistance to broomrape in wild lentils (Lens spp.). Plant Breeding 128: 266-270.

Ferreira, J. J., Campa, A., Pérez-Vega, E., Rodríguez-Suárez, C., and Giraldez, R. 2012. Introgression and pyramiding into common bean market class fabada of genes conferring resistance to anthracnose and potyvirus. Theor. Appl. Genet. 124: 777-788.

Fiala, J. V., Tullu, A., Banniza, S., Séguin-Swartz, G., and Vandenberg A. 2009. Interspecies Transfer of resistance to anthracnose in lentil (Lens culinaris Medic.). Crop Sci. 49: 825-830.

Finckha, M. R., Gacekb, E. S., Goyeau, H., Lannou, C., Merzd, U., Mundte, C. C., Munk, L., Nadziak, J., Adrian, G., Newton, C., de Vallavieille-Pope, C., and Wolfe, M. S. 2000. Cereal variety and species mixtures in practice, with emphasis on disease resistance. Agronomie 20: 813-837.

Fory, L. F., Finardi-filho, F., Quintero, C. M., Osborn, T. C., Cardona, C., Chrispeels, M. J., and Mayer, J. E. 1996. Alpha-amylase inhibitors in resistance of common beans to the Mexican bean weevil and the bean weevil (Coleoptera bruchidae). J. Econ. Entomol. 89: 204-210.

Foucher, F., Morin, J., Courtiade, J., Cadioux, S., Ellis, N., Banfield, M., and Rameau, C. 2003. DET and LF are two TFL1/CEN homologues controlling two distinct phases of flowering initiation and development in pea. Plant Cell 15: 2742-2754.

Gabriel, I., Lessire, M., Juin, H., Burstin, J., Duc, G., Quillien, L., Thibault, J. F., Leconte, M., Hallouis, J. M., Ganier, P., Mèzière, N., and Sève, B. 2008. Variation in seed protein digestion of different pea (Pisum sativum L.) genotypes by cecectomized broiler chickens: 1 . Endogenous amino acid losses, true digestibility and in vitro hydrolysis of proteins. Livest. Sci. 113: 251-261.

Gahoonia, T. S., Ali, O., Sarker, A., Rahman, M. M., and Erskine, W. 2005. Root traits, nutrient uptake, multi-location grain yield and benefit-cost ratio of two lentil (Lens culinaris M.) varieties. Plant Soil 272: 153-161.

Galeano, C. H., Cortés, A. J., Fernández, A. C., Soler, A., Franco-Herrera, N., Makunde, G., Vanderleyden, J., and Blair, M. W. 2012. Gene-based single nucleotide polymorphism markers for genetic and association mapping in common bean. BMC Genet. 13: 48.

Gan, Y. 2012. Optimizing crop rotations and minimizing plant diseases. PulsePoint Magazine January: 10-11. Blairmore Media, Saskatoon, Saskatchewan, Canada.

Gaur, P. M., Krishnamurphy, L., and Kashiwagi, J. 2008. Improving droughtavoidance root traits in chickpea (Cicer arietinum L.) - current status of research at ICRISAT. Plant Prod. Sci. 11: 3-11.

Geffroy, V., Sévignac, M., Billant, P., Dron, M., and Langin, T. 2008. Resistance to Colletotrichum lindemuthianum in Phaseolus vulgaris: a case study for mapping two independent genes. Theor. Appl. Genet. 116: 407-415.

Gepts, P., and Bliss, F. A. 1988. Dissemination pathways of common bean (Phaseolus vulgaris, Fabaceae) deduced from phaseolin electrophoretic variability. II. Europe and Africa. Econ Bot. 42: 86-104.
Gil, J., and De Ron, A. M. 1992. Variation in Phaseolus vulgaris in the northwest of the Iberian Peninsula. Plant Breeding 109: 313-319.

Gladstones, J. S. 1994. An historical review of lupins in Australia. In: Proceedings of 1st Lupin Technical Symposium, Perth, WA, pp. 1-38. Dracup, M., and Palta, J. A., Eds., Western Department of Agriculture. Perth, Australia.

Gomez-Roldan, V., Fermas, S., Brewer, P. B., Puech-Pagès, V., Dun E. A., Pillot, J. P., Letisse, F., Danoun, S., Portais, J. C., Bouwmeester, H., Becard, G., Beveridge, C. A., Rameau, C., and Rochange, S. F. 2008. Strigolactone inhibition of shoot branching. Nature 455: 189-194.

González, A. M., De la Fuente, M., De Ron, A. M., and Santalla, M. 2010. Protein markers and seed size variation in common bean segregating populations. Mol. Breeding 25: 723-740.

González, A. M., Monteagudo, A. B., Casquero, P. A., De Ron, A. M., and Santalla, M. 2006. Genetic variation and environmental effects on agronomical and commercial quality traits in the main European market classes of dry bean. Field Crop. Res. 95: 336-347.

González, A. M., Rodiño, A. P., Santalla M., and De Ron, A. M. 2009. Genetics of intra-gene pool and inter-gene pool hybridization for seed traits in common bean (Phaseolus vulgaris L.) germplasm from Europe. Field Crop. Res. 112: 66-76.

Ghosh, P. K., Mohanty, M., Bandyopadhyay, K. K., Painuli, D. K., and Misra, A. K. 2006a. Growth, competition, yield advantage and economics in soybean/pigeonpea intercropping system in semi-arid tropics of India: I. Effect of subsoiling. Field Crop. Res. 96: 80-89.

Ghosh, P. K., Mohanty, M., Bandyopadhyay, K. K., Painuli, D. K., and Misra, A. K. 2006b. Growth, competition, yields advantage and economics in soybean/pigeonpea intercropping system in semi-arid tropics of India: II. Effect of nutrient management. Field Crop. Res. 96: 90-97.

Gil-Quintana, E., Larrainzar, E., Seminario, A., Díaz-Leal, J. L., Alamillo, J. M., Pineda, M., Arrese-Igor, C., Wienkoop, S., and González, E. M. 2013. Local inhibition of nitrogen fixation and nodule metabolism in drought-stressed soybean. J. Exp. Bot. 64: 2171-2182.

Gossen, B. D., Hwang, S. F., Conner, R. L., and Chang, K. F. 2011. Managing the ascochyta blight complex on field pea in western Canada. Prairie Soils and Crops 4: 135-141.

Gulati, A., Schryer, P., and McHughen, A. 2001. Regeneration and micrografting of lentil shoots. In Vitro Cell. Dev. Pl. 37: 798-802.

Gurung, A. M., Pang, E. C. K, and Taylor, P. W. J. 2002. Examination of Pisum and Lathyrus species as sources of ascochyta blight resistance for field pea (Pisum sativum). Aust. Plant Pathol. 31: 41-45.

Gurusamy, V., Warkentin, T. D., and Vandenberg, A. 2012. Grafting pea, faba bean and lentil to improve pulse crop breeding. Can. J. Plant Sci. 90: 299-304.

Hanocq, E., Jeuffroy, M. H., Lejeune-Hénaut, I., and Munier-Jolain, N. 2009. Construire des idéotypes pour des systèmes de culture variés en pois d'hiver. Innovations Agronomiques 7: 14-28.

Haque, A., Hossain, M., Wouters, G., and Lambein, F. 1996. Epidemiological study of lathyrism in northwestern districts of Bangladesh. Neuroepidemiology 15: 83-91.

Hauggaard-Nielsen, H., Jørnsgaard, B., Kinane, J., and Jensen, E. S. 2007. Grain legume-cereal intercropping: the practical application of diversity, competition and facilitation in arable and or organic cropping systems. Renew. Agr. and Food Syst. 23: 3-12.

Herridge, D. F., Peoples, M. B., and Boddey, R. M. 2008. Marschner review: Global inputs of biological nitrogen fixation in agricultural systems. Plant Soil 311: 1-18.

Hogekamp, C., and Küster, H. 2013. A roadmap of cell-type specific gene expression during sequential stages of the arbuscular mycorrhiza symbiosis. BMC Genomics 14: 306.

Hondelmann, W. 1984. The Lupin-ancient and modern crop plant. Theor. Appl. Genet. 68: 1-9.

Hood-Niefer, S. D., Warkentin, T. D., Chibbar, R. N., Vandenberg, A., and Tyler, T. 2012. Effect of genotype and environment on the concentrations of starch and protein in, and the physicochemical properties of starch from, field pea and faba bean. J. Sci. Food Agric. 92: 141-150. 
Huyghe, C. 1991. Winter growth of autumn sown white lupin (Lupinus albus L.): main apex growth model. Ann. Bot.-London 67: 429-434.

Jensen, E. S., Peoples, M. B., Boddey, R. M., Gresshoff, P. M., HauggaardNielsen, H., Alves B. J. R., and Morrison M. J. 2012. Legumes for mitigation of climate change and the provision of feedstock for biofuels and biorefineries: a review. Agron. Sustain. Dev. 32: 329-364.

Jeuffroy, M.H., Baranger, E., Carrouée, B., de Chezelles, E., Gosme, M., Hénault, C., Schneider, A., and Cellier, P. 2012. Nitrous oxide emissions from crop rotations including wheat, rapeseed and dry pea. Biogeosciences Discussion 9: 9289-9314.

Jukanti, A. K., Guar, P. M., Gowda, C. L. L., and Chibbar, R. N. 2012. Nutritional quality and health benefits of chickpea (Cicer arietinum L.): a review. $\mathrm{Br}$. $\mathrm{J}$. Nutr. 108: S11-S26.

Jumel, S., Rouault, F., Lemarchand E., and Tivoli, B. 2010. Effect and underlying mechanisms of pea-cereal intercropping on the epidemic development of ascochyta blight. Eur. J. Plant Pathol. 126: 317.

Kadžiulienè, Ž., Šarūnaite, L., and Deveikyte, I. 2011. Effect of pea and spring cereals intercropping on grain yield and crude protein content. Ratar. Povrt. 48: $183-188$.

Kalavacharla, V., Liu, Z., Meyers, B. C., Thimmapuram, J., and Melmaiee, K. 2011. Identification and analysis of common bean (Phaseolus vulgaris L.) transcriptomes by massively parallel pyrosequencing. BMC Plant Biol. 11: 135.

Kaplan, L. 1981. What is the origin of common bean? Econ. Bot. 35: 240-254.

Karagić, Đ., Mikić, A., Milošević, B., Vasiljević, S., and Dušanić, N. 2012. Common vetch-wheat intercropping: haylage yield and quality depending on sowing rates. Afr. J. Biotechnol. 11: 7637-7642.

Karel, A., 1993. Effects of intercropping with maize on the incidence and damage caused by pod borers of common beans. Environmental entomology 22: $1076-1083$.

Kaul, A. K., Islam, M. Q., and Hamid, A. 1986. Screening of Lathyrus germplasm of Bangladesh for BOAA content and some agronomic characters. In: Lathyrus and Lathyrism, pp. 130-141. Kaul, A. K., Combes, D., Eds., Third World Medical Research Foundation, New York.

Khan, T. N., Timmerman-Vaughan, G. M., Rubiales, D., Warkentin, T. D., Siddique, K. H. M., Erskine, W., and Barbetti, M. J. 2013. Didymella pinodes and its management in field pea: challenges and opportunities. Field Crop. Res. 148: 61-77.

Kislev, M. E. 1989. Origins of the cultivation of Lathyrus sativus and Lathyrus cicera (Fabaceae). Econ. Bot. 43: 262-270.

Krussel, L., Madsen, L. H., Sato, S., Aubert, G., Genu, A., Szczygowski, D., Duc, G., Tabata, S., Bruijn, F., Pajuelo E., Sandal, N., and Stougaard, J. 2002. Shoot control of nodule and root development is mediated by e serine/threonine receptor kinase. Nature 420: 422-426.

Krussel, L., Sato N., Fukuhara, I., Koch, B. E. V., Grossmann, C., Okamoto, S., Oka-kira, E., Otsubo, Y., Aubert, G., Nakagawa, T., Sato, S., Tabata, S., Duc, G., Parniske, M., Wang, T. L., Kawaguchi, M., and Stougaard, J. 2011. The Clavata2 genes of pea and Lotus japonicus affect autoregulation of nodulation. Plant J. 65: 861-871.

Kumar, S., Bejiga, G., Ahmed, S., Nakkoul, H., and Sarker, A. 2011. Genetic improvement of grass pea for low neurotoxin (b-ODAP) content. Food Chem. Toxicol. 49: 589-600.

Kurlovich, B.S. 2002. The History of Lupin Domestication. In: Lupins, Geography, Classification, Genetic Resources and Breeding, pp. 147-164. Kurlovich, B. S. Ed., OY International Express. St. Petersburg, Russia.

Laguerre, G., Depret, G., Bourion, V., and Duc, G. 2007. Rhizobium leguminosarum bv. viciae genotypes interact with pea plants in developmental responses of nodules, roots and shoots. New Phytol. 176: 680690.

Landa, B. B., Navas-Cortés, J. A., and Jiménez-Díaz, R. M. 2004. Integrated management of Fusarium wilt of chickpea with sowing date, host resistance, and biological control. Phytopathology 94: 946-960.

Leitão, S. T., Almeida, N. F., Moral, A., Rubiales, D., and Vaz Patto, M. C. 2013. Identification of resistance to rust (Uromyces appendiculatus) and powdery mildew (Erysiphe diffusa) in Portuguese common bean germplasm. Plant Breeding 132: 654-657.

Lejeune-Henaut, I., Hanocq, E., Bethencourt, L., Fontaine, V., Delbreil, B., Morin, J., Petit, A., Devaux, R., Boilleau, M., Stempniak, J. J., Thomas, M., Laine, A. L., Foucher, F., Baranger, A., Burstin, J., Rameau, C., and Giauffret C. 2008. The flowering locus Hr colocalizes with a major QTL affecting winter frost tolerance in Pisum sativum L. Theor. Appl. Gen. 116: $1105-1116$

Leport, L., Turner N. C., French, R. J., Tennant, D., Thomson, B. D., and Siddique, K. H. M. 1998. Water relations, gas exchange and growth of coolseason grain legumes in a Mediterranean-type environment. Eur. J. Agron. 9: 295-303.

Lie, T. A. 1984. Host genes in Pisum sativum L. Conferring resistance to European Rhizobium leguminosarum strains. Plant Soil 82: 415-425.

Link, W., Stelling, D., and Ebmeyer, E. 1994. Factors determining the performance of synthetics in Vicia faba L. 1.Heterogeneity, heterozygosity, and degree of cross-fertilization. Euphytica 75: 77-84.

Lioi, L. 1989. Geographical variation of phaseolin patterns in an old world collection of Phaseolus vulgaris. Seed Sci. Technol. 17: 317-324.

Limongelli, G., Laghetti, G., Perrino, P., and Piergiovanni, A. R. 1996. Variation of seed storage proteins in landraces of common bean (Phaseolus vulgaris L.) from Basilicata, Southern Italy. Euphytica 92: 393-399.

McPhee, K. 2005. Variation for seedling root architecture in the core collection of pea germplasm. Crop Sci. 45: 1758-1763.

Mihailović, V., and Mikić, A. 2010. Novel directions of breeding annual feed legumes in Serbia. Biotechnol. Anim. Husb. 26: 81-90.

Mihailović, V., Mikić, A., and Ćupina, B. 2007a. Potential of annual legumes for utilisation in animal feeding. Biotechnol. Anim. Husb. 23: 573-581.

Mihailović, V., Mikić, A., Ćupina, B., and Erić, P. 2005b. Field pea and vetches in Serbia and Montenegro. Grain Legumes 44: 25-26.

Mihailović, V., Mikić, A., Cupina, B., Krstić, Đ., Antanasović, S., and Radojević, V. 2013. Forage yields and forage yield components in grass pea (Lathyrus sativus L.). Legum. Res. 36: 67-69.

Mihailović, V., Mikić, A., Ćupina, B., Krstić, Đ., Erić, P., Hauptvogel, P., and Karagić, Đ. 2009b. Forage yields in urban populations of Hungarian vetch (Vicia pannonica Crantz) from Serbia. Grassl. Sci. Eur. 14: 417-420.

Mihailović, V., Mikić, A., Đorđević, V., Ćupina, B., Perić, V., Krstić, Đ., Srebrić, M., Antanasović, S., and Devine, T. E. 2012. Performance of forage soya bean (Glycine max) cultivars in the Northern Balkans. In: Breeding Strategies for Sustainable Forage and Turf Grass Improvement, pp. 353-358. Barth, S., and Milbourne, D., Eds., Springer Science+Business Media, Dordrecht.

Mihailović, V., Mikić, A., Ćupina, B., Vasiljević, S., Krstić, Đ., Tomić, Z., and Vasić, M. 2007b. Genetic resources of annual forage legumes in the world and Serbia. Ratar. Povrt. 44: 115-123.

Mihailović, V., Mikić, A., Erić, P., Vasiljević, S., Ćupina, B., and Katić, S. 2005a. Protein pea in animal feeding. Biotechnol. Anim. Husb. 21: 281-285.

Mihailović, V., Mikić, A., Kobiljski, B., Ćupina, B., Antanasović, S., Krstić, D., and Katanski, S. 2011. Intercropping pea with eight cereals for forage production. Pisum Genet. 43: 33-35.

Mihailović, V., Mikić, A., Vasiljević, S., Katić, S., Karagić, Đ., and Ćupina, B. 2008. Forage yields in urban populations of hairy vetch (Vicia villosa Roth) from Serbia. Grassl. Sci. Eur. 13: 281-283.

Mihailović, V., Mikić, A., Vasiljević, S., Milić, D., Ćupina, B., Krstić, Đ., and Ilić O. 2006. Tropical legumes for forage. Grassl. Sci Eur. 11: 306-308.

Mihailović, V., Šibalić, I., Mikić, A., Milić, D., Vasiljević, S., and Lukić, D. 2003. Production and usage of pea grain in animal and human nutrition. Biotechnol. Anim. Husb. 19: 457-464.

Mihailović, V., Warkentin, T., Mikić, A, and Ćupina, B. 2009a. Challenges for forage pea breeders. Grain Legumes 52: 20-21.

Mikić, A., Ćupina, B., Katić, S., and Karagić, D. 2006. Importance of annual forage legumes in supplying plant proteins. Ratar. Povrt. 42: 91-103.

Mikić, A., Ćupina, B., Mihailović, V., Krstić, D., Đorđević, V., Perić, V., Srebrić, M., Antanasović, S., Marjanović-Jeromela, A., and Kobiljski, B. 2012. Forage legume intercropping in temperate regions: Models and ideotypes. In: 
Sustainable Agriculture Reviews, Vol. 11, pp. 161-182. Lichtfouse, E., Ed., Springer Science+Business Media, Dordrecht.

Mikić, A., Mihailović, V., Ćupina, B., Antanasović, S., Krstić, Đ., Zlatković, B., Đorđević, V., Zorić, L., Taški-Ajduković, K., and Nagl, N. 2013a. Ex situ evaluation of cultivation potential in wild populations of large-flowered vetch (Vicia grandiflora). Euphytica 193: 1-12.

Mikić, A., Mihailović, V., Ćupina, B., Đorđević, V., Milić, D., Duc, G., Stoddard, F. L., Lejeune-Hénaut, I., Marget, P., and Hanocq, E. 2011b. Achievements in breeding autumn-sown annual legumes for temperate regions with emphasis on the continental Balkans. Euphytica 180: 57-67.

Mikić, A., Mihailović, V., Ćupina, B., Đorđević, V., and Stoddard, F. L. $2010 \mathrm{~b}$. Introduction of novel legume crops in Serbia - White lupin (Lupinus albus). Ratar. Povrt. 47: 21-26.

Mikić, A., Mihailović, V., Ćupina, B., Đurić, B., Krstić, Đ., Vasić, M., Vasiljević, S., Karagić, Đ., and Đorđević V. 2011a. Towards the re-introduction of grass pea (Lathyrus sativus) in the West Balkan Countries: the case of Serbia and Srpska (Bosnia and Herzegovina). Food Chem. Toxicol. 49: 650-654.

Mikić, A., Mihailović, V., Ćupina, B., Kosev, V., Warkentin, T., McPhee, K., Ambrose, M., Hofer, J., and Ellis, N. 2011c. Genetic background and agronomic value of leaf types in pea (Pisum sativum). Ratar. Povrt. 48: 275-284.

Mikić, A., Mihailović, V., Ćupina, B., Krstić, Đ., Hauptvogel, R., Drobná, J., and Antalíková, G. 2009a. Forage yields in urban populations of large-flowered vetch (Vicia grandiflora Scop.) from Serbia. Grassl. Sci. Eur. 14: 421-424.

Mikić, A., Mihailović, V., Ćupina, B., Krstić, Đ., Vasiljević, S., and Milić, D. 2010a. Forage and seed yield components in four French landraces of grass pea (Lathyrus sativus L.). In: Sustainable Use of Genetic Diversity in Forage and Turf Breeding, pp. 127-130. Huyghe, C., Ed., Springer Science+Business Media, Dordrecht.

Mikić, A., Mihailović, V., Ćupina, B., Milić, D., Katić, S., Karagić, Đ., Pataki, I., D'Ottavio, P., and Kraljević-Balalić, M. 2013b. Forage yield components and classification of common vetch (Vicia sativa L.) cultivars of diverse geographic origin. Grass Forage Sci. First published online: 22 Feb 2013, DOI: $10.1111 /$ gfs. 12033 .

Mikić, A., Mihailović, V., Ćupina, B., Vasiljević, S., Krstić, Đ., and Milić, D. 2008. Forage yields in urban populations of narrow-leafed vetch (Vicia sativa subsp. nigra (L.) Ehrh.) from Serbia. Grassl. Sci. Eur. 13: 284-286.

Mikić, A., Mihailović, V., Ćupina, B., Vishyakova, M., Vasić, M., Đorđević, V., and Perić, V. 2009b. Forage and grain yields in the VIR accessions of narbonne vetch Vicia narbonensis in the conditions of Serbia. Bull. Appl. Bot. Genet. Plant Breed. 188: 185-188.

Mikić, A., Mihailović, V., Katić, S., Karagić, Đ., and Milić, D. 2003. Protein pea grain - a quality fodder. Biotechnol. Anim. Husb. 19: 465-471.

Mikić, A., Mihailović, V., Mikić, V., Milić, D., Vasiljević, S., Katić, S., and Radić, V. 2009c. Agronomic characteristics of genus Vigna L. related to forage. Ratar. Povrt. 46: 207-211.

Mikić, A., Mihailović V., Vasiljević S., Krstić Đ., and Katić S. 2007. Potential of the less widespread species of annual legumes for forage - faba bean (Vicia faba L.). Ratar. Povrt. 43: 263-267.

Miller, P. R., Waddington, J., Mcdonald, C. L., and Derksen, D. A. 2002. Cropping sequence affects wheat productivity on the semiarid northern Great Plains. Can. J. Plant Sci. 82: 307-318.

Mohd-Radzman, N.A., Djordjevic, M.A., Imin, N. 2013. Nitrogen modulation of legume root architecture signalling pathways involves phytohormones and small regulatory molecules. Front. Plant Sci. 4: 385.

Mollard, R.C., Luhovyy, B. L., Panahi, S., Nunez, M., Hanley, A., and Anderson, G. H. 2012. Regular consumption of pulses for 8 weeks reduces metabolic syndrome risk factors in overweight and obese adults. Br. J. Nutr. 108: S111-S122.

Monteagudo, A. B., Rodiño, A. P., Lema, M., De la Fuente, M., Santalla, M., De Ron, A. M., and Singh, S. P. 2006. Resistance to fungal, bacterial and viral diseases in a common bean core collection from the Iberian Peninsula. HortScience 41: 319-322.

Morandi, D., Sagan, M., Prado-Vivant, E., and Duc, G. 2000. Influence of genes determining supernodulation of Pisum sativum and Medicago truncatula mu- tants on the root infection by mycorrhizal fungus Glomus. Mycorrhiza 10: $37-42$.

Mudryj, A., Yu, N., Hartman, T. J., Mitchell, D. C., Lawrence, F. R., and Aukema, H. M. 2012. Pulse consumption in Canadian adults influences nutrient intakes. Br. J. Nutr. 108: S27-S36.

Muehlbauer, F. J., Mihov, M., Vandenberg, A., Tullu, A. and Materne, M. 2009. Improvement in developed countries. In: The Lentil: Botany, Production and Uses, pp. 137-154. Erskine, W., Muehlbauer, F., Sarkar, A., and Sharma, B., Eds., CAB International, London.

Mulumba, J. W., Nankya, R., Adokorach, J., Kiwuka, C., Fadda, C., De Santis, P., and Jarvis, D. I. 2012. A risk-minimizing argument for traditional crop varietal diversity use to reduce pests and disease damage in agricultural Uganda. Agric. Ecosyst. Environ. 157: 70-86.

Mundt, C.C. 2002. Use of multiline cultivars and cultivar mixtures for disease management. Annu. Rev.Phytopathol. 40: 381-410.

Nakaya, A. and Isobe, S. 2012. Will genomic selection be a practical method of plant breeding? Ann. Bot.-London 110: 1303-1316.

Naudin, C., Corre-Hellou, G., Pineau, S., Crozat, Y., and Jeuffroy, M. H. 2010. The effect of various dynamics of $\mathrm{N}$ availability on winter pea-wheat intercrops: Crop growth, N partitioning and symbiotic N2 fixation. Field Crop. Res. 119: 2-11.

Nicolas, M. F., Hungria, M., and Arias, C. A. A. 2006. Identification of quantitative trait loci controlling nodulation and shoot mass in progenies from two Brazilian soybean cultivars. Field Crop. Res. 95: 355-366.

Nodari, R. O., Tsai, S. M., Guzman, P., Gilbertson, R. L., and Gepts, P. 1993. Toward an integrated linkage map of common bean. III. Mapping genetic factors controlling host-bacteria interactions. Genetics 134: 341-350.

Oblessuc, P. R., Borges, A., Chowdhury, B., Caldas, D. G. G, Tsai, S. M., Camargo, L. E. A, and Melotto, M. 2012. Dissecting Phaseolus vulgaris Innate Immune System against Colletotrichum lindemuthianum Infection. PLoS ONE 7: e43161. DOI:10.1371/journal.pone.0043161.

Oldroyd, G. E. D., and Downie, A. 2008. Coordinating Nodule morphogenesis with rhizobial Infection ln Legumes. Annu. Rev. Plant Biol. 59: 519-546.

Ortwin-Sauer, C. 1966. The Early Spanish Man. University of California Press, Berkeley and Los Angeles. 306 pp.

Palmer, R. G., Pérez, P. T., Ortiz-Pérez, E., Maalouf, F., and Suso, M. J. 2009. The role of crop/pollinator relationship understanding in breeding for pollinator-friendly legume varieties from a breeding perspective. Euphytica 170: $35-52$.

Pastor-Corrales, M. A., Otoya, M. M., Molina, A., and Singh, S. P. 1995. Resistance to Colletotrichum limdemuthianum isolates from Middle America and Andean South America in different common bean races. Plant Dis. 79: 63-67.

Peix, A., Ramírez-Bahena, M. H., Velázquez, E., and Bedmar, E. J. 2014. Bacterial associations with legumes. Crit. Rev. Pl. Sci., this issue.

Picard, J., and Duc, G. 1986. "Côte d'Or", a highly frost resistant population of faba bean. Fabis Newsl. 13: 11-12.

Pelzer, E., Bazot, M., Makowski, D., Corre-Hellou, G., Naudin, C., Al Rifaï, M., Baranger, E., Bedoussac, L., Biarnès, V., Boucheny, P., Carrouée, B., Dorvillez, D., Foissy, D., Gaillard, B., Guichard, L., Mansard, M. C., Omon, B., Prieur, L., Yvergniaux, M., Justes, E., and Jeuffroy, M. H. 2012. Pea-wheat intercrops in low-input conditions combine high economic performances and low environmental impacts. Eur. J. Agr. 40: 39-53.

Pérez-Vega, E., Pañeda, A., Rodríguez-Suárez, C., Campa, A., Giraldez, R., and Ferreira, J. J. 2010. Mapping of QTLs for morpho-agronomic and seed quality traits in a RIL population of common bean (Phaseolus vulgaris L.). Theor. Appl. Genet. 120: 1367-1380.

Pérez-Vega, E., Trabanco, N., Campa, A., and Ferreira, J. J. 2013. Genetic mapping of two genes conferring resistance to powdery mildew in common bean (Phaseolus vulgaris L.). Theor. Appl. Genet. 126:1503-1512.

Pilet-Nayel, M. L., Muehlbauer, F. J., McGee, R. J., Kraft, J. M., Baranger, A., and Coyne, C. J. 2005. Consistent QTLs in pea for partial resistance to Aphanomyces euteiches isolates from United States and France. Phytopathology 95 : $1287-1293$. 
Plans, M., Simo, J., Casanas, F., and Sabate, J. 2012. Near-infrared spectroscopy analysis of seed coats of common beans (Phaseolus vulgaris L.): a potential tool for breeding and quality evaluation. J. Agr. Food Chem. 60: 706712.

Podder, R., Banniza, S., and Vandenberg, A. 2013. Screening of wild and cultivated of lentil germplasm for resistance to stemphylium blight. Plant Gen. Res.: Char. and Util. 11: 26-35.

Prioul-Gervais, S., Deniot, G., Receveur, E. M., Frankewitz, A., Fourmann, M., Rameau, C., Pilet-Nayel, M. L., and Baranger, A. 2007. Candidate genes for quantitative resistance to Mycosphaerella pinodes in pea (Pisum sativum L.). Theor. Appl. Genet. 114: 971-984.

Ramaekers, L., Galeano, C. H., Garzon, N., Vanderleyden, J., and Blair, M. W. 2013. Identifying quantitative trait loci for symbiotic nitrogen fixation capacity and related traits in common bean. Mol. Breeding 31: 163-180.

Ramaekers, L., Remans, R., Rao, I. M., Blair, M. W., and Vanderleyden, J. 2010. Strategies for improving phosphorus acquisition efficiency of crop plants. Field crop. Res. 117: 169-176.

Rao, S. C. and Northup, B. K. 2008. Planting data affects production and quality of grass pea forage. Crop Sci. 48: 1629-1635.

Rasmusson, D. 1987. An evaluation of ideotype breeding. Crop Sci. 27: 1140-1146.

Redden, R. J., Yadav, S. S., Hatfield, J. L., Prasanna, B. M., Vasal, S. K., and Lafarge, T. 2011. The Potential of Climate Change Adjustment in Crops: A Synthesis. In: Crop Adaptation to Climate Change, pp. 482-494. Yadav, S. S., Redden, R. J., Hatfield, J. L., Lotze-Campen, H., and Hall A. E., Eds., Wiley \& Sons Ltd, Wiley-Blackwell, Oxford, UK. DOI: 10.1002/9780470960929.ch33.

Rehman, A. U., Malhotra, R. S., Bett, K., Taran, B., Bueckert, R., and Warkentin, T. D. 2011. Mapping QTL associated with traits affecting grain yield in chickpea (Cicer arietinum L.) under terminal drought stress. Crop Sci. 51: 450-463.

Reid, D. E., Ferguson, B. J., Hayashi, S., Lin, Y. H., and Gresshoff, P. 2011. Molecular mechanisms controlling legume autoregulation of nodulation. Ann. Bot.-London 108: 789-795.

Riveiro, M. 2012. Tolerancia de variedades de judía a estrés hídrico estacional e implicaciones en la fijación simbiótica de Nitrógeno. Ph. D. Thesis. University of Santiago de Compostela. Spain. 238 pp.

Robertson, J. R., and Abd El-Moneim, A. M. 1996. Lathyrus germplasm collection, conservation and utilization for crop improvement at ICARDA. In Proceedings of Lathyrus Genetic Resources in Asia, a Regional Workshop. Indira Gandhi Agricultural University, Raipur, India, pp. 97-111. Arora, R. K., Mathur, P. N., Riley, K. W., and Adham, Y., Eds., IPGRI, Office for South Asia, New Delhi, India.

Rodiño, A. P., De La Fuente, M., De Ron, A. M., Lema, M. J., Drevon, J. J., and Santalla, M. 2011. Variation for nodulation and plant yield of common bean genotypes and environmental effects on the genotype expression. Plant Soil 346: 349-361.

Rodiño, A. P., González, A. M., Santalla, M., De Ron, A. M., and Singh, S. P. 2006a. Novel genetic variation in common bean from the Iberian Peninsula. Crop Sci. 46: 2540-2546.

Rodiño, A. P., Monteagudo, A. B., De Ron, A. M., and Santalla, M. 2009. Ancestral landraces of common bean from the south of Europe and their agronomical value for breeding programs. Crop Sci. 49: 2087-2099.

Rodiño, A. P., Lema, M., Pérez-Barbeito, M., Santalla, M., and De Ron, A. M. 2007a. Assessment of runner bean (Phaseolus coccineus L.) germplasm for tolerance to low temperature during early seedling growth. Euphytica $\mathbf{1 5 5}$ : 63-70.

Rodiño, A. P., Riveiro, M., Santalla, M., and De Ron, A. M. 2007b. Sources of variation of common bean for drought tolerance. Annual Report Bean Improvement Cooperative 50: 163-164.

Rodiño, A. P, Santalla, M., and De Ron, A. M. 2006b. Respuesta de Phaseolus sp. a estrés por bajas temperaturas. Actas de Horticultura 45: 151-152.

Rodiño, A. P., Santalla M., De Ron A. M., and Drevon J. J. 2010. Co-evolution and migration of bean and rhizobia in Europe. In: Sustainable Agriculture
Reviews, Vol 3, pp. 171-188. Lichtfouse, E., Ed., Springer Science+Business Media, Dordrecht.

Rubiales, D., and Fernández-Aparicio, M. 2012. Innovations in parasitic weeds management in legume crops. A review. Agron. Sustain. Dev. 32: 433-449.

Rubiales, D., and Fondevilla, S. 2012. Future prospects for Ascochyta blight resistance breeding in cool season food legumes. Front. Plant Sci. 3: 27.

Rubiales, D., Fondevilla, S., Chen, W., Gentzbittel, L., Higgins, T. J. V., Castillejo, M. A., Singh, K. B., and Rispail, N. 2014. Achievements and challenges in legume breeding for pest and disease resistance. Crit. Rev. Plant Sci. this issue.

Sagan, M., and Duc, G. 1996. Sym 28 and Sym29, two new genes involved in regulation of nodulation in pea (Pisum sativum L.). Symbiosis 20: 229245.

Sagan, M., Messager, A., and Duc, G. 1993. Specificity of the Rhizobiumlegume symbiosis obtained after mutagenesis in pea (Pisum sativum L.). New Phytol. 125: 757-761.

Salon, C., Munier-Jolain, N. G., Duc, G., Voisin, A. S., Grandgirard, D., Larmure, A., Emery, R. J. N., and Ney, B. 2001. Grain legume seed filling in relation to nitrogen acquisition: a review and prospects with particular reference to pea. Agronomie 21: 539-552.

Sandlin, C. M., Steadman, J. R., Araya, C. M., and Coyne D. P. 1999. Isolates of Uromyces appendiculatus with specific virulence to landraces of Phaseolus vulgaris of Andean origin. Plant Dis. 83: 108-113.

Santalla, M., Amurrio, J. M., Rodiño, A. P., and De Ron, A. M. 2001b. Variation in traits affecting nodulation of common bean under intercropping with maize and sole cropping. Euphytica 122: 243-255.

Santalla, M., Casquero, P. A., and De Ron, A. M. 1999. Yield and yield components from intercropping improved bush bean cultivars with maize. J. Agron. Crop Sci. 183: 263-269.

Santalla, M., De Ron, A. M., and Casquero, P. A. 1995. Nutritional and culinary quality of bush bean populations intercropped with maize. Euphytica 84: $57-65$.

Santalla, M., De Ron, A. M., and Escribano, M. R. 1994. Effect of intercropping bush bean populations with maize on agronomic traits and their implication for selection. Field Crop. Res. 36: 185-189.

Santalla, M., De Ron, A. M., and Voysest, O. 2001a. European bean market classes. In: Catalogue of Bean Genetic Resources, pp. 77-94. Amurrio, M., Santalla, M., and De Ron, A. M., Eds., Fundación Pedro Barrié de la Maza / PHASELIEU-FAIR3463 / MBG-CSIC. Pontevedra, Spain.

Santalla, M., González, A. M., Lema, M., Rodiño, A. P., Monteagudo, A. B., and De Ron, A. M. 2005. Improvement of large-seeded common bean cultivars under sustainable cropping systems in Spain. Euphytica 142: 85-95.

Santalla, M., Rodiño, A. P, and De Ron, A. M. 2002. Allozyme evidence supporting southwestern Europe as a secondary center of genetic diversity for common bean. Theor. Appl. Genet. 104: 934-944.

Sarunaite, L., Kadziuliene, Z., Deveikyte, I., and Kadziulis, L. 2013. Effect of legume biological nitrogen on cereals grain yield and soil nitrogen budget in double-cropping system. J. Food Agric. Environ. 11: 528-533.

Schnabel, E. L., Kassaw, T. K., Smith, L. S., Marsh, J. F., Oldroyd, G.E., Long, S. R., and Frugoli, J. A. 2011. The root determined nodulation1 gene regulates nodule number in rootsof Medicago truncatula and defines a highly conserved, uncharacterized plant gene family. Plant Physiol. 157: 328-340.

Sengbusch, R., and Zimmermann, K. 1937. Die Auffindung der ersten gelben und blauen Lupine (Lupinus luteus und Lupinus angustifolius) mit nicht platzenden Hülsen und die damit zusammenhängenden Probleme der Süßlupinenzüchtung. Züchter 9: 57-65.

Sharma, H. C., Gowda, C. L. L,. Stevenson, P. C, Ridsdill-Smith, T. J., Clement, S. L., Ranga Rao, G. V., Romies J., Miles, M., and El Bouhssini, M. 2006. Host plant resistance and insect pest management. In: Chickpea. pp. 527-544. Yadav, S., Ed. CAB international.

Shi, C., Chaudhary, S., Yu, K., Park, S. J., Navabi, A., and McClean, P. E. 2011. Identification of candidate genes associated with $\mathrm{CBB}$ resistance in common bean HR45 (Phaseolus vulgaris L.) using cDNA-AFLP. Mol. Biol. Rep. 38 $75-81$. 
Siddique, K. H. M., Regan, K. L., Tennant, D., and Thomson, B. D. 2001. Water use and water use efficiency of cool season grain legumes in low rainfall Mediterranean-type environments. Eur. J. of Agron. 15: 267.

Sillero, J. C., Villegas-Fernández, A. M., Thomas, J., Rojas-Molina, M. M., Emeran, A. A., Fernández-Aparicio, M., and Rubiales, D. 2010. Faba bean breeding for disease resistance. Field Crop. Res. 115: 297-307.

Silvestre, S., Araújo, S. S., Vaz Patto, M. C., and Marques da Silva, J. 2014. Phenotyping the physiological responses of nine Lathyrus genotypes to water deficit with the chlorophyll a fluorescence transient. J. Int. Plant Biol. (accepted for publication).

Simon, C. J. and Hannan, R. H. 1995. Development and use of core subsets of cool-season food legume germplasm collections. HortScience 30: 907.

Skiba, B., Ford, R., and Pang, E. C. K. 2004. Construction of a linkage map based on a Lathyrus sativus backcross population and preliminary investigation of QTLs associated with resistance to ascochyta blight. Theor. Appl. Genet. 109: 1726-1735.

Slinkard, A. E., Solh, M. B., and Vandenberg, A. 2000. Breeding for yield: The direct approach. In:Linking Research and Marketing Opportunities for Pulses in the 21st Century, pp. 183-190. Knight,R. Ed., Kluwer Academic Publishers. Netherlands.

Smartt, J. 1984. Evolution of Grain Legumes. I. Mediterranean Pulses. Exp Agric 20: 275-296.

Smiths, R. G., Gross, K. L., and Robertson, G. P. 2008. Effect of crop diversity on agroecosystem: crop yield response. Ecosystems 11: 355-366.

Smýkal, P., Coyne, C. J., Ambrose, M. J., Maxted, N., Schaefer, H., Blair, M. W., Berger, J., Greene, S. L., Nelson, M. N., Besharat, N., Vymyslický, T., Toker, C., Saxena, R. K., Roorkiwal, M., Pandey, M. K., Hu, J., Li, Y. H.,Wang, L. X., Guo, Y., Qiu, L. J., Redden, R. J., and Varshney, R. K. 2014. Legume crops phylogeny and genetic diversity for science and breeding. Crit. Rev. Pl. Sci. this issue.

Souza, A. A, Boscariol, R. L., Moon, D. H., Camargo, L. E. A., and Tsai, S. M. 2000. Effects of Phaseolus vulgaris QTL in controlling host-bacteria interactions under two levels of nitrogen fertilization. Genet. Mol. Biol. 23: 155-161.

Spies, J. M., Warkentin, T. D., and Shirtliffe, S. J. 2011. Variation in field pea (Pisum sativum) cultivars for basal branching and weed competition. Weed Sci. 59: 218-223.

Stoddard, F. L., Nicholas, A. H., Rubiales, D., Thomas, J., and Villegas, A. M. 2010. Integrated pest management in faba bean. Field Crop. Res. 115: 308-318.

Sumita Acharjee, A., Sarmah, B. K., Kumar, P. A., Olsen, K., Mahon, R., Moar, W. J., Moore, A., and Higgins, T. J. V. 2010. Transgenic chickpeas (Cicer arietinum L.) expressing a sequence-modified cry2Aa gene. Plant Sci. 178: 333-339.

Sun, L., Cheng, X., and Wang, L. 2007. Current Progress in Research of Bruchid Resistance in Mungbean. J. Plant Genet. Res. 8: 113-117.

Sun, L., Cheng, X., Wang, S., Wang, L., Liu, C., Mein, L., and Xu N. 2008. Heredity analysis and gene mapping of bruchid resistance of a mungbean cultivar V2709. Scientia Agricultura Sinica 41: 1291-1296.

Tahir, M., Vandenberg, A., and Chibbar, R. N. 2011. Influence of environment on seed soluble carbohydrates in selected lentil cultivars. J. Food Compos. Anal. 24: 596-602.

Talukdar, D. 2011. Morpho-physiological responses of grass pea (Lathyrus sativus L.) genotypes to salt stress at germination and seedling stages. Legume Res. 34: 232-241.

Thavarajah, D., Thavarajah, P., Amarakoon, D., Fenlason, A., Johnson, C. R., Knutson, P., and Warkentin, T. D. 2013. Changes in inositol phosphates in low phytic acid field pea (Pisum sativum L.) lines during germination and in response to fertilization. Am. J. Plant Sci. 4: 251-256.

Thavarajah, D., Vandenberg, A., George, G. N., and Pickering, I. J. 2007. Chemical form of Selenium in naturally Selenium-rich lentils (Lens culinaris L.) from Saskatchewan. J. Agric. Food Chem. 55: 7337-7341.

Thavarajah, D., Warkentin, T. D., and Vandenberg, A. 2010. Natural enrichment of Selenium in Saskatchewan field peas (Pisum sativum L.). Can. J. Plant Sci. 90: 383-389.
Thompson, B.D., Siddique, K. H. M., Barr, M. D., and Wilson, J. M. 1997. Grain legume species in low rainfall Mediterranean-type environment. I. Phenology and seed yield. Field Crop. Res. 54: 173-187.

Tivoli, B., Baranger, A., Avila, C. M., Banniza, S., Barbetti, M., Chen, W., Davidson, J., Lindeck, K., Kharrat, M., Rubiales, D., Sadiki, M., Sillero, J. C., Sweetingham, M., and Muehlbauer, F. J., 2006. Screening techniques and sources of resistance to foliar diseases caused by major necrotrophic fungi in grain legumes. Euphytica 147: 223-253.

Torres, A. M., Román, B., Avila, C., Satovic, Z., Rubiales, D., Sillero, J. C., Cubero, J. I., and Moreno, M. T., 2006. Faba bean breeding for resistance against biotic stresses: towards application of marker technology. Euphytica 147: $67-80$.

Toro, M., Azcon, R., and Barea, J. M. 1998. The use of isotopic dilution techniques to evaluate the interactive effects of Rhizobium genotype, mycorrhizal fungi, phosphate-solubilizing bacteria and rock phosphate on nitrogen and phosphorus acquisition by Medicago sativa. New Phytol. 138: 265-273.

Trabanco, N., Pérez-Vega, E., Campa, A., Rubiales, D., and Ferreira, J. J., 2012. Genetic resistance to powdery mildew in common bean. Euphytica 186: $875-882$.

Tullu, A., Buchwaldt, L., Lulsdorf, M., Banniza, S., Barlow, B., Slinkard, A. E., Sarker, A., Taran, B., Warkentin, T., and Vandenberg, A. 2006. Sources of resistance to anthracnose (Colletotrichum truncatum) in wild Lens species. Genet. Resour. Crop Evol. 53: 111-119.

Tullu, A., Diederichsen, A., Suvorova, G., and Vandenberg, A. 2010. Genetic and genomic resources of lentil: Status, use and prospects. Plant Genet. Resour. 9: 19-29.

Ubayasena, L., Bett, K., Taran, B., Perumal, V., and Warkentin, T. 2010. Genetic control and QTL analysis of cotyledon bleaching resistance in green field pea (Pisum sativum L.). Genome 53: 346-359.

Ubayasena, L., Vijayan, P., Bett, K., Gray, G. R., Küster, H., and Warkentin, T. 2013. Gene expression profiles of seed coats and biochemical properties of seed cats and cotyledons of two field pas (Pisum sativum L.) cultivars contrasting in green cotyledon bleaching resistance. Euphytica 193: 49-65.

Unkovich, M.J., and Pate, J.S., 2000. An appraisal of recent field measurements of symbiotic $\mathrm{N}_{2}$ fixation by annual legumes. Field Crop. Res. 65: 211228.

Upadhyaya, H. D., Dwivedi, S. L., Ambrose, M., Ellis, N., Berger, J., Smykal, P., Debouck, D., Duc, G., Dumet, D., Flavell, A., Sharma, S. K., Mallikarjuna, N., and Gowda, C. L. L. 2011. Legume genetic resources: management, diversity assessment, and utilization in crop improvement. Euphytica 180: 27-47.

Vadez, V., Soltani, A., and Sinclair, T. R. 2012. Modelling possible benefits of root related traits to enhance terminal drought adaptation of chickpea. Field Crop. Res. 137: 108-115.

Vail, S., and A. Vandenberg. 2010. Evaluation of a clonal propagation protocol to obtain replicated disease data on infection by Colletotrichum truncatum in Lens culinaris. Crop Sci. 50: 926-932.

Vasconcelos Garcia, R. A., Rangel, P. N., Bassinello, P. Z., and VianelloBrondani, R. P. 2012. QTL mapping for the cooking time of common beans. Euphytica 186: 779-792.

Vaz Patto, M. C., Amarowicz, R., Aryee, A. N. A., Boye, J. I., Chung, H. J., Martín-Cabrejas, M. A., and Domoney, C. 2014. Achievements and challenges in improving the nutritional quality of food legumes. Crit. Rev. Pl. Sci. this issue.

Vaz Patto, M. C., Fernández-Aparicio, M., Moral, A., and Rubiales, D. 2006 b. Characterization of resistance to powdery mildew (Erysiphe pisi) in a germplasm collection of Lathyrus sativus. Plant Breeding 125: 308-310.

Vaz Patto, M. C., Fernández-Aparicio, M., Moral, A., and Rubiales, D. 2009. Pre and posthaustorial resistance to rusts in Lathyrus cicera. Euphytica $\mathbf{1 6 5}$ : 27-34.

Vaz Patto, M. C., Hanbury, C. D., Van Moorhem, M., Lambein, F., Ochatt, S., and Rubiales, D. 2011. Grass Pea. In: Genetics, Genomics and Breeding of Cool Season Grain Legumes, pp. 151-204. Perez de la Vega, M., Cubero, J. I., and Torres, A. M. Eds., CRC Press, Boca Raton FL \& Science Publishers, Enfield, NH. 
Vaz Patto, M. C. and Rubiales, D. 2009. Identification and characterization of partial resistance to rust in a germplasm collection of Lathyrus sativus. Plant Breeding 128: 495-500.

Vaz Patto, M.C., Skiba, B., Pang, E. C. K., Ochatt, S. J., Lambein, F., and Rubiales, D. 2006a. Lathyrus improvement for resistance against biotic and abiotic stresses: from classical breeding to marker assisted selection. Euphytica 147: 133-147.

Vocanson, A. and Jeuffroy, M. H. 2007. Agronomic performance of different pea cultivars under various sowing periods and contrasting soil structures. Agron. J. 3: 748-759.

Vollman, J., Wagentrist, H., and Hart, W. 2010. The effects of simulated weed pressure on early maturity soybeans. Eur. J. Agron. 32: 243-248.

Walley, F. L., Clayton, G. W., Miller, P. R., Carr, P. M., and Lafond, G. P. 2007. Nitrogen economy of pulse crop production in the Northern Great Plains. Agron. J. 99: 1710-1718.

Warkentin, T. D., Delgerjav, O., Arganosa, G., Rehman, A. U., Bett, K. E., Anbessa, Y., Rossnagel, B., and Raboy, V. 2012. Development and characterization of low-phytate pea. Crop Sci. 52: 74-78.

Warkentin, T., Klassen, E., Bing, D., Lopetinsky, K., Kostiuk, J., Barlow, B., Ife, S., Taran, B., and Vandenberg, B. 2009. CDC Tucker and CDC Leroy forage pea cultivars. Can. J. Plant Sci. 89: 661-663.

Weigand, S., Lateef, S. S., El Din Sharaf, N., Mahmoud, S. F., Ahmed, K., and Ali, K. 1994. Integrated control of insect pests of cool season food legumes. In: Expanding the Production and Use of Cool Season Food Legumes. pp. 679-694. Muehlbauer, E. J. and Kaiser, W. J., Ed. Kluwer Academic, Dordrecht, The Netherlands.

Williams, J. D. and McHughen, A. 1986. Plant regeneration of the legume Lens culinaris Medik in vitro. Plant Cell Tiss. Org. 7: 149-153.

Wright, A. T. 1990. Yield effects of pulses on subsequent cereal crops in the northern prairies. Can. J. Plant Sci. 70: 1023-1032.

Wright, E. M., and J. D. Kelly. 2011. Mapping QTL for seed yield and canning quality following processing of black bean (Phaseolus vulgaris L.). Euphytica 179: 471-484.

Yadava, S. S., Kumara, J., Yadava, S. K., Singha, S., Yadava, V. S, Turner, N. C., and Redden, R. 2006. Evaluation of Helicoverpa and drought resistance in desi and kabuli chickpea. Plant. Genet. Resour. 4: 198-203.

Yang, H. M., Zhang, X. Y., and Wang, G. X. 2004. Relationships between stomatal character, photosynthetic character and seed chemical composition in grass pea at different water availabilities. J. Agr. Sci. 142: 675-681.
Yuan, H. Y., Lulsdorf, M., Tullu, A., Gurusamy, V., and Vandenbeg, A. 2011. In vitro grafting of wild Lens species to Vicia faba rootstocks. Plant Genet. Resour. 9: 543-548.

Yuste-Lisbona, F. J., Santalla, M., Capel, C., García-Alcázar, M., De la Fuente, M., Capel, J., De Ron, A. M., and Lozano, R. 2012. Marker-based linkage map of Andean common bean (Phaseolus vulgaris L.) and mapping of QTLs underlying popping ability traits. BMC Plant Biol. 12: 136.

Zahaf, O., Blanchet, S., de Zélicourt, A., Alunni, B., Plet, J., Laffont, C., de Lorenzo, L., Imbeaud, S., Ichanté, J.L., Diet, A., Badri, M., Zabalza, A., González, E.M., Delacroix, H., Gruber, H., Frugier, F., and Crespi, M. 2012. Comparative transcriptomic analysis of salt adaptation in roots of contrasting Medicago truncatula genotypes. Mol. Plant 5: 1068 1081

Zancarini, A., Lepinay, C., Burstin, J., Duc, G., Lemanceau, P., Moreau, D., Munier-Jolain, N., Pivato, B., Rigaud, T., Salon, C., and Mougel, C. 2013. Combining molecular microbial ecology with ecophysiology and plant genetics for a better understanding of plant-microbial communities interactions in the rhizosphere. In: Molecular Microbial Ecology of the Rhizosphere vol. 1, pp. 69-86. De Bruijn, F. J., Ed., Wiley-Blackwell, Hoboken, NJ.

Zaugg, I., Magni, C., Panzeri, D., Daminati, M. G., Bollini, R., Benrey, B., Bacher, S., and Sparvoli, F. 2013. QUES, a new Phaseolus vulgaris genotype resistant to common bean weevils, contains the Arcelin-8 allele coding for new lectin-related variants. Theor. Appl. Genet. 126: 647661.

Zeven, A. C. 1997. The introduction of the common bean (Phaseolus vulgaris L.) into Western Europe and the phenotypic variation of dry beans collected in the Netherlands in 1946. Euphytica 94: 319-328.

Zhang, F., and Li, L. 2003. Using competitive and facilitative interactions in intercropping systems enhances crop productivity and nutrient use efficiency. Plant Soil 248: 305-312.

Zhang, W., Ricketts, T. H., Kremen, C., Carney, K., and Swinton, S. M. 2007. Ecosystem services and dis-services to agriculture. Ecol. Econ. 64: 253260.

Zhu, H., Riely, B. K., Burns, N. J., and Ane, J. M. 2006. Tracing nonlegume orthologs of legume genes required for nodulation and arbuscular mycorrhizal symbioses. Genetics 172: 2491-2499.

Zivcák, M., Brestic, M., Olsovská, K., and Slamka, P. 2008. Performance index as a sensitive indicator of water stress in Triticum aestivum L. Plant Soil Environ. 54: 133-139. 